
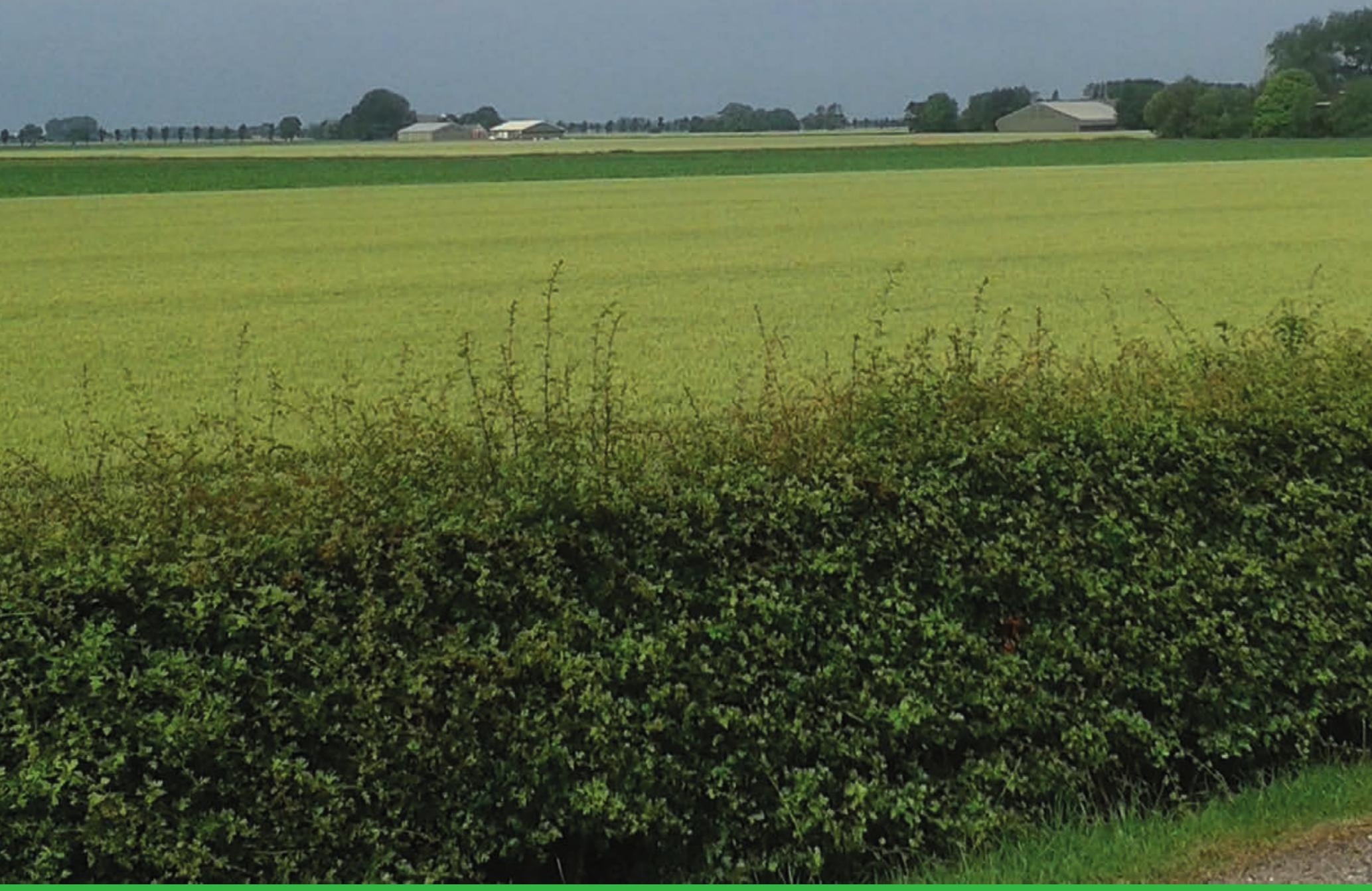

\title{
Actualisatie van stikstof- en fosfaatgehalten van akkerbouwgewassen met een groot areaal
}





\section{Actualisatie van stikstof- en fosfaatgehalten van akkerbouwgewassen met een groot areaal}

F.J. de Ruijter ${ }^{1}$, W. van Dijk ${ }^{1}$, W.C.A. van Geel ${ }^{1}$, G. Holshof ${ }^{1}$, R. Postma ${ }^{2}$, P. Wilting ${ }^{3}$

Gereviewd door:

J.C. van Middelkoop, Senior onderzoeker, Wageningen University \& Research

1 Wageningen University \& Research

2 Nutriënten Management Instituut BV

3 Stichting IRS

Dit onderzoek is uitgevoerd door de Stichting Wageningen Research (WR), business units Agrosysteemkunde en Open Teelten, Nutriënten Management Instituut BV en Stichting IRS, en gesubsidieerd door het Ministerie van Landbouw, Natuur en Voedselkwaliteit als Additioneel onderzoek in het kader van het $6^{\mathrm{e}}$ Actieprogramma Nitraatrichtlijn (projectnummer 37104636 00).

WR is een onderdeel van Wageningen University \& Research, samenwerkingsverband tussen Wageningen University en de Stichting Wageningen Research.

Wageningen, april 2020

Rapport WPR-957 
F.J. de Ruijter, W. van Dijk, W.C.A. van Geel, G. Holshof, R. Postma, P. Wilting, 2020. Actualisatie van stikstof- en fosfaatgehalten van akkerbouwgewassen met een groot areaal. Wageningen Research, Rapport WPR-957. 96 blz.; 6 fig.; 20 tab.; 23 ref.

Dit rapport is gratis te downloaden op https://doi.org/10.18174/520624

Gewasopbrengsten zijn in de loop der jaren veranderd, en ten behoeve van het mestbeleid is inzicht nodig in de mate waarin de afvoer met stikstof $(N)$ en fosfaat $(P)$ ook is gewijzigd. Afvoer van $N$ en $P$ wordt veelal berekend uit min of meer gemeten opbrengsten en gewasspecifieke verstekwaarden voor de $\mathrm{N}$ - en P-gehalten. Deze verstekwaarden zijn grotendeels ontleend aan proeven van tientallen jaren geleden. Zo wordt nog veel gebruik gemaakt van de database 'Kiezen uit Gehalten III' die goeddeels gebaseerd is op een publicatie van Beukeboom uit 1996, en de Adviesbasis voor de bemesting van akkerbouw- en vollegrondsgroentengewassen van Van Dijk uit 2003. Er zijn aanwijzingen dat gestegen opbrengsten samengaan met gedaalde gehalten, waardoor een actualisatie van $\mathrm{N}$ - en $\mathrm{P}$-gehalten in geoogst product nodig is.

$\mathrm{N}$ - en P-gehaltes zijn bepaald voor bouwlandgewassen met een groot areaal. Hiervoor is een uitgebreide dataset opgezet met voornamelijk gegevens uit het onderzoek en deels uit de praktijk voor de periode 1990-2019. N- en P-gehaltes zijn voornamelijk bepaald op basis van situaties met bemesting rondom het adviesniveau. Ten opzichte van eerder gehanteerde verstekwaarden zijn $\mathrm{N}$-gehalten uit de voorliggende studie lager, met uitzondering van consumptieaardappelen waarbij het gehalte vergelijkbaar was, en zetmeelaardappelen en snijmais waarbij het gehalte hoger was. De P-gehalten uit de voorliggende studie zijn lager voor consumptieaardappelen, suikerbieten en granen, vergelijkbaar voor pootaardappelen en peen, en hoger voor zetmeelaardappelen, ui en snijmais. Voor een aantal gewassen heeft grondsoort invloed op het $\mathrm{N}$ - of P-gehalte en zijn afzonderlijke gehalten voor klei en zand gegeven. Opbrengstniveau heeft soms effect op het gehalte: $\mathrm{N}$ - en P-gehalten nemen af met toenemend opbrengstniveau bij de gewassen suikerbiet, zaaiui en wintertarwe. Dit is ook het geval voor de N-gehalten bij snijmais en korrelmais, en het P-gehalte bij zomergerst. Bij de gewassen pootaardappel en korrelmais werd voor het P-gehalte juist een hoger gehalte gevonden met toenemend opbrengstniveau.

Trefwoorden: N-gehalte, P-gehalte, bouwland, zand, klei, opbrengst

(C) 2020 Wageningen, Stichting Wageningen Research, Wageningen Plant Research, Business unit Agrosysteemkunde, Postbus 16, 6700 AA Wageningen; T 03174807 00; www.wur.nl/plant-research

KvK: 09098104 te Arnhem

VAT NL no. 8113.83.696.B07

Stichting Wageningen Research. Alle rechten voorbehouden. Niets uit deze uitgave mag worden verveelvoudigd, opgeslagen in een geautomatiseerd gegevensbestand, of openbaar gemaakt, in enige vorm of op enige wijze, hetzij elektronisch, mechanisch, door fotokopieën, opnamen of enige andere manier zonder voorafgaande schriftelijke toestemming van Stichting Wageningen Research.

Stichting Wageningen Research is niet aansprakelijk voor eventuele schadelijke gevolgen die kunnen ontstaan bij gebruik van gegevens uit deze uitgave.

Rapport WPR-957

Foto omslag: Frank de Ruijter 


\section{Inhoud}

$\begin{array}{ll}\text { Samenvatting } & 5\end{array}$

1

$\begin{array}{ll}\text { Inleiding } & 7\end{array}$

$\begin{array}{lll}1.1 & \text { Achtergrond } & 7\end{array}$

1.2 Doel en afbakening $\quad 8$

2

$\begin{array}{ll}\text { Materiaal en methoden } & 9\end{array}$

2.1 Algemeen $\quad 9$

2.2 Databronnen 10

$\begin{array}{llr}2.3 \text { Stikstof } & 10\end{array}$

2.3.1 Beschikbare $\mathrm{N}$ en $\mathrm{N}$-advies $\quad 10$

2.3.2 N-gehalte in het gewas 14

$\begin{array}{lll}2.4 & \text { Fosfaat } & 14\end{array}$

2.4.1 Fosfaattoestand en fosfaatbemestingsadvies $\quad 14$

$\begin{array}{lll}2.5 & \text { Standaard drogestofgehalten } & 16\end{array}$

$\begin{array}{lll}2.6 & \text { Bewerking en analyse van de data } & 17\end{array}$

$\begin{array}{llr}3 & \text { Resultaten } & 18\end{array}$

$3.1 \quad$ Verzamelde data $\quad 18$

$3.2 \mathrm{~N}$ - en P-gehalten per gewas $\quad 22$

3.3 Effect van opbrengstniveau op N- en P-gehalte $\quad 24$

3.4 Effect van consumptieaardappelras op N- en P-gehalte 26

$\begin{array}{lll}3.5 & \text { Vergelijking huidige gehalten met eerdere cijfers } & 27\end{array}$

4 Discussie $\quad 31$

$5 \quad$ Conclusies $\quad 33$

$\begin{array}{ll}\text { Literatuur } & 34\end{array}$

Bijlage 1 Overzicht databronnen $\quad 35$

Bijlage 2 Waardering van de fosfaattoestand van de bodem op basis van Pw-getal

Bijlage 3 Aantal waarnemingen voor het $\mathbf{N}$-gehalte per gewas grondsoort - jaar combinatie

Bijlage 4 Aantal waarnemingen voor het P-gehalte per gewas grondsoort - jaar combinatie $\quad 47$

Bijlage 5 Spreiding in gehalten en opbrengst bij verschillende bemesting 48

Bijlage 6 Resultaten analyses - stikstofgehalten $\quad 70$

$\begin{array}{lll}\text { Bijlage } 7 & \text { Resultaten analyses - fosforgehalten } & 74\end{array}$

$\begin{array}{lll}\text { Bijlage } 8 & \text { Figuren van geselecteerde data } & 78\end{array}$

$\begin{array}{lll}\text { Bijlage } 9 & \text { Fabrieksbalans fosfaat suikerbieten } & 94\end{array}$ 



\section{Samenvatting}

Gewasopbrengsten zijn in de loop der jaren veranderd, en ten behoeve van het mestbeleid is inzicht nodig in de mate waarin de afvoer met stikstof $(N)$ en fosfaat $(P)$ ook is gewijzigd. Afvoer van $N$ en $P$ wordt veelal berekend uit min of meer gemeten opbrengsten en gewasspecifieke verstekwaarden voor de $\mathrm{N}$ - en P-gehalten. Deze verstekwaarden zijn grotendeels ontleend aan proeven van tientallen jaren geleden. Zo wordt nog veel gebruik gemaakt van de database 'Kiezen uit Gehalten III' die goeddeels gebaseerd is op een publicatie van Beukeboom uit 1996, en de Adviesbasis voor de bemesting van akkerbouw- en vollegrondsgroentengewassen van Van Dijk uit 2003. Er zijn aanwijzingen dat gestegen opbrengsten samengaan met gedaalde gehalten, waardoor een actualisatie van $\mathrm{N}$ - en $\mathrm{P}$-gehalten in geoogst product nodig is.

$\mathrm{N}$ - en P-gehaltes zijn bepaald voor bouwlandgewassen met een groot areaal: consumptieaardappelen, pootaardappelen, zetmeelaardappelen, suikerbieten, zaai-uien, wintertarwe, zomertarwe, wintergerst, zomergerst, peen, snijmais en korrelmais. Hiervoor is een uitgebreide dataset opgezet met voornamelijk gegevens uit het onderzoek en deels uit de praktijk voor de periode 1990-2019. N- en Pgehaltes zijn voornamelijk bepaald op basis van situaties met bemesting rondom het adviesniveau; bij te weinig data is een bredere range gebruikt. Ten opzichte van eerder gehanteerde verstekwaarden zijn N-gehalten uit de voorliggende studie lager, met uitzondering van consumptieaardappelen waarbij het gehalte vergelijkbaar was, en zetmeelaardappelen en snijmais waarbij het gehalte hoger was. De P-gehalten uit de voorliggende studie zijn lager voor consumptieaardappelen, suikerbieten en granen, vergelijkbaar voor pootaardappelen en peen, en hoger voor zetmeelaardappelen, ui en snijmais.

Voor een aantal gewassen heeft grondsoort invloed op het $\mathrm{N}$ - of P-gehalte en zijn afzonderlijke gehalten voor klei en zand gegeven. Opbrengstniveau heeft soms effect op het gehalte: $\mathrm{N}$ - en P-gehalten nemen af met toenemend opbrengstniveau bij de gewassen suikerbiet, zaaiui en wintertarwe. Dit is ook het geval voor de $\mathrm{N}$-gehalten bij snijmais en korrelmais, en het P-gehalte bij zomergerst. Bij de gewassen pootaardappel en korrelmais werd voor het P-gehalte juist een hoger gehalte gevonden met toenemend opbrengstniveau. 


\section{$1 \quad$ Inleiding}

Het Zesde Actieprogramma Nitraatrichtlijn (LNV, 2017) merkt op dat gestegen en/of bovengemiddelde gewasopbrengsten een verruiming van gebruiksnormen kunnen rechtvaardigen (paragraaf 3.2.1.1). Het Zesde Actieprogramma geeft daarom aan dat bij de evaluatie van het stelsel van gebruiksnormen rekening gehouden moet worden met de veranderde gemiddelde opbrengsten (maatregel 5.2.1) en met afwijkende opbrengsten (maatregel 5.2.5 en 5.3.4). In dit onderzoek worden de stikstof- en fosforgehalten in een aantal gewassen geactualiseerd en, waar relevant, gedifferentieerd naar onder andere opbrengst. Dit levert informatie op over de vraag in hoeverre een hogere opbrengst ook leidt tot een hogere stikstof- en/of fosfaatafvoer en dus een hogere stikstof- en/of fosfaatbehoefte. Deze gegevens zijn nodig voor actualisering van gebruiksnormen op basis van nieuwe inzichten in gehalten, opbrengsten en teeltwijzen.

\subsection{Achtergrond}

Voor goede gewasgroei dienen telers nutriënten zoals stikstof $(N)$ en fosfor $(P)$ toe. Dit gebeurt voor een belangrijk deel via meststoffen: organische mest en kunstmest. Om de belasting van grond- en oppervlaktewater met $\mathrm{N}$ en $\mathrm{P}$ te minimaliseren, moet de aanvoer van $\mathrm{N}$ en $\mathrm{P}$ in overeenstemming zijn met de afvoer vermeerderd met de toelaatbare of onvermijdelijke verliezen. Wat een teler aanvoert is doorgaans redelijk bekend op basis van beschikbare chemische analyses (gecertificeerde meststoffen, vervoersbewijzen dierlijke mest en verplichte mest-analyses), maar wat hij afvoert is in veel gevallen gebaseerd op de combinatie van min of meer gemeten opbrengsten en gewasspecifieke verstekwaarden voor de $\mathrm{N}$ - en $\mathrm{P}$-gehalten. Jaarlijkse meting van de chemische samenstelling van ieder individueel oogstproduct is namelijk kostbaar. De aldus veronderstelde afvoer vormt ook de basis voor de berekening van bodemoverschotten. De uitkomst van dergelijke berekeningen wordt gebruikt in adviessystemen voor telers, voor de onderbouwing van de N- en P-gebruiksnormen en ten behoeve van (inter-)nationale monitoringsverplichtingen inzake milieubelasting door de landbouw. Het is daarom belangrijk om van verstekwaarden uit te gaan die een zo goed mogelijke weergave van de werkelijkheid zijn.

De verstekwaarden die op dit moment gebruikt worden zijn onderwerp van discussie geworden. Telersorganisaties geven aan dat autonoom gestegen gewasopbrengsten een navenante opwaartse bijstelling van $\mathrm{N}$ - en P-gebruiksnormen rechtvaardigen. Het bodemoverschot, en in verband daarmee de milieubelasting, zou als gevolg van een dergelijke bijstelling immers onveranderd blijven. In reactie hierop wordt vanuit het landbouwkundig onderzoek aangegeven dat hogere opbrengsten bij een aantal gewassen hand in hand blijken te gaan met verlaagde gehalten ('verdunningseffect') (Ten Berge et al., 2012; 2017; Van der Schoot en Van Dijk, 2001). Gestegen opbrengsten betekenen derhalve niet automatisch dat de $\mathrm{N}$ - en $\mathrm{P}$-afvoer in gelijke mate is gestegen. Een verhoging van gebruiksnormen die procentueel gelijke tred houdt met de opbrengststijging, zou daarom tot een hogere milieubelasting leiden.

Verstekwaarden voor N- en P-gehalten voor zijn grotendeels ontleend aan proeven van, vermoedelijk, tientallen jaren geleden. Het is daarom denkbaar dat als gevolg van gestegen opbrengsten die gehalten de huidige werkelijkheid overschatten. Zo wordt in studies ter advisering van de Ministeries van EZK en LNV doorgaans gebruik gemaakt van de verstekwaarden uit de database 'Kiezen uit Gehalten III' die goeddeels gebaseerd is op een publicatie van Beukeboom uit 1996. Deze waarden worden ook weergegeven in Van Dijk (2003), waarbij voor een aantal gewassen (o.a. broccoli, stamslaboon) de gehalten zijn aangepast op basis van een in 2001 uitgevoerde studie met destijds recente gegevens van $\mathrm{N}$ - en $\mathrm{P}$-gehalten van akkerbouw- en vollegrondsgroentengewassen (Van der Schoot en Van Dijk, 2001). Voor zover de relaties tussen opbrengsten en gehalten bekend zijn, is deze informatie moeilijk te gebruiken om die gedateerde gehalten te actualiseren naar de 
huidige opbrengstniveaus. Het is namelijk onbekend op welk opbrengstniveau die veel gebruikte verstekwaarden als die in Beukeboom (1996) en Van Dijk (2003) betrekking hebben.

Ehlert et al. (2006) hebben het verloop van opbrengsten en P-gehalten van een aantal gewassen over een lange reeks van jaren bekeken. Voor snijmais, suikerbiet, rogge en zomergerst werden geen significante veranderingen in het P-gehalte gevonden. Voor aardappel, wintertarwe en zomertarwe daalde het P-gehalte, en steeg de opbrengst. De P-afvoer bleef bij aardappel hierdoor min of meer constant. Bij tarwe steeg de P-afvoer minder hard dan de opbrengst. Voortbouwend op dit onderzoek hebben Ehlert et al. (2009) voor een brede reeks van gewassen een overzicht gemaakt van P-gehalten in afgevoerd product. Deze P-gehalten verschillen voor veel gewassen met die welke gegeven worden door Beukeboom (1996) en Van Dijk (2003), en zijn naast elkaar gezet in Schröder en Van Dijk (2017). Bij sommige groentengewassen geven Ehlert et al. (2009) hogere P-gehalten dan Beukeboom (1996) en Van Dijk (2003). Voor de akkerbouwgewassen met een groot areaal daarentegen zijn met uitzondering van zetmeelaardappelen en uien de P-gehalten zoals gegeven door Ehlert et al. (2009) lager dan die uit Beukeboom (1996) en Van Dijk (2003).

Bij N-gehalten zijn vergelijkbare veranderingen gevonden als bij P-gehalten. Schröder en Van Dijk (2017) citeren Ten Berge et al. (2012) en geven aan dat verdunning leidt tot een lager $\mathrm{N}$-gehalte voor iedere ton meeropbrengst aan vers (marktbaar) product van 0,04 kg N per ton bij snijmais, 0,02 bij suikerbiet, 0,03 bij consumptieaardappel, 0,04 bij fabrieksaardappel, 0,02 bij zaaiui, 0,20 bij wintertarwe, 0,19 bij zomertarwe en 0,15 bij zomergerst.

Voor berekening van de actuele $\mathrm{N}$ - en P-afvoer met geoogst product is informatie over huidig opbrengstniveau en huidig gehalte nodig. Schröder en Van Dijk (2017) hebben hiervoor berekeningen uitgevoerd op basis van N-gehalten zoals vermeld door Beukeboom (1996) en Van Dijk (2003), en P-gehalten zoals vermeld door Ehlert et al. (2009). Het eerdergenoemde negatieve verband tussen opbrengsten en gehalten is door Schröder en Van Dijk (2017) nog niet meegenomen omdat nog niet duidelijk was op welk opbrengstniveau de gebruikte verstekwaarden betrekking hebben. Zij adviseren daarom om $\mathrm{N}$ - en $\mathrm{P}$-gehalten te updaten, en een verband te leggen tussen gehalten en het opbrengstniveau.

\subsection{Doel en afbakening}

Het doel van de voorliggende studie is om van bouwlandgewassen met een groot areaal de $\mathrm{N}$ - en P-gehalten van het geoogste product te actualiseren. De focus ligt hierbij op akkerbouwgewassen (inclusief snijmais) die tezamen minimaal $90 \%$ van het bouwlandareaal innemen. Gras wordt hierbij niet meegenomen omdat de schatting van de $\mathrm{N}$ - en P-afvoer via de Kringloopwijzer loopt o.a. op basis van gemeten gehalten in de kuilen. Dat geldt voor snijmais in principe ook, maar omdat de teelt van snijmais deels ook plaatsvindt op akkerbouwbedrijven, is een geüpdatet forfaitair gehalte van belang om de $\mathrm{N}$ - en $\mathrm{P}$-afvoer op akkerbouwbedrijven te kunnen inschatten. Bij de actualisatie worden ook factoren bekeken die het gehalte kunnen beïnvloeden, zoals opbrengst, ras, bemesting, bodemvruchtbaarheid (o.a. P-toestand) en grondsoort.

De resultaten van dit onderzoek kunnen in vervolgonderzoek gebruikt worden, bijvoorbeeld voor verkenningen van varianten van gebruiksnormen, waarbij de $\mathrm{N}$ - en $\mathrm{P}$-afvoer en $\mathrm{N}$ - en P-bodemoverschotten een rol spelen. 


\section{Materiaal en methoden}

\section{$2.1 \quad$ Algemeen}

Een bureaustudie is uitgevoerd waarin gegevens uit onderzoek en praktijk zijn verzameld met betrekking tot $\mathrm{N}$ - en $\mathrm{P}$-gehalten van de grootste bouwlandgewassen die tezamen ongeveer $90 \%$ van het Nederlandse akker- en tuinbouwareaal (incl. snijmais) beslaan (Tabel 2.1). Hierbij is uitgegaan van bestaande gegevens: er zijn geen nieuwe metingen gedaan, en alleen gegevens voor Nederlandse teelt zijn verzameld.

Tabel 2.1 Gewassen met grootste areaal in 2016 die tezamen ongeveer 90\% van het Nederlandse akker- en tuinbouwareaal beslaan (incl. snijmais, excl. grasland. Bron: CBS).

\begin{tabular}{lr} 
Gewas & Oppervlak (ha) \\
Snijmais & 206870 \\
\hline Wintertarwe & 117010 \\
\hline Consumptieaardappelen & 73320 \\
\hline Suikerbieten & 70720 \\
\hline Zetmeelaardappelen & 43170 \\
\hline Pootaardappelen & 41410 \\
\hline Zaai-uien & 25080 \\
\hline Zomergerst & 24980 \\
\hline Zomertarwe & 11050 \\
\hline Graszaden & 9970 \\
\hline Wintergerst & 9820 \\
\hline Korrelmais & 9120 \\
\hline Winterpeen & 6640 \\
\hline
\end{tabular}

Gegevens voor de periode 1990-2019 zijn meegenomen, waarbij het zwaartepunt van dataverzameling lag bij recente data van de periode 2006-2013. Voor sommige gewassen zijn ook gegevens van eerdere jaren dan 1990 aanwezig; deze zijn wel opgenomen in de database maar verder niet gebruikt bij de analyses voor het voorliggende rapport. Dit omdat de insteek was om de $\mathrm{N}$ en $\mathrm{P}$-gehalte te actualiseren op basis van relatief recente data.

De analyses zijn gericht op de grondsoorten klei en zand. Veengrond en löss zijn niet bekeken. Wel bevat de database enkele gegevens voor veengrond met snijmais. In de praktijk is het areaal snijmais op veengrond echter zeer beperkt. Ook zijn er gegevens voor löss met de gewassen consumptieaardappel, snijmais, suikerbiet en wintertarwe, hoofdzakelijk voor de jaren ' 90.

Gegevens vanuit proeven en praktijk over N- en P-gehalten met bijbehorende teeltinformatie zijn verzameld (Tabel 2.2). Bij proeven zijn de gemiddelden per proefobject ingevoerd (gemiddelde van herhalingen). 
Tabel 2.2 Verzamelde gegevens vanuit proeven en praktijk.

\begin{tabular}{|c|c|c|}
\hline Info & Info & Info \\
\hline Algemeen & Bemesting & Oogstgegevens \\
\hline Gewas & $\mathrm{P}_{2} \mathrm{O}_{5}$-gift $(\mathrm{kg} / \mathrm{ha})$ & versopbrengst (ton/ha) \\
\hline proef of praktijk & - toedieningswijze (rij of volvelds) & $\mathrm{N}$-gehalte in drogestof (\%) \\
\hline plot of heel veld & - kunstmest & P-gehalte in drogestof (\%) \\
\hline Jaar & N-gift (kg/ha) & P-gehalte in vers (\%) \\
\hline Grondsoort & - organische mest & \\
\hline voorvrucht ${ }^{1}$ & - kunstmest & Overig \\
\hline Locatie & - kunstmest rij (snijmais) ${ }^{1}$ & bron \\
\hline \multicolumn{3}{|l|}{ P-toestand } \\
\hline \multicolumn{3}{|l|}{ - $\mathrm{Pw}$} \\
\hline \multicolumn{3}{|l|}{ - $\mathrm{P}-\mathrm{CaCl} 2$} \\
\hline - P-Al & & \\
\hline
\end{tabular}

\subsection{Databronnen}

Data zijn afkomstig van:

- WUR:

- Wageningen Plant Research (WPR): de onderdelen Agrosysteemkunde en Open Teelten (OT),

- Wageningen Livestock Research (WLR).

- NMI,

- Stichting IRS.

De informatie is deels beschreven in rapporten en voor een deel alleen vastgelegd in interne databestanden. Een complete lijst met databronnen wordt gegeven in Bijlage 1.

Data zijn aangeleverd in Excelbestanden met informatie zoals gegeven in Tabel 2.2 en samengevoegd tot één databestand met bijna 24000 regels.

\section{$2.3 \quad$ Stikstof}

Voor stikstof is de totale $\mathrm{N}$-gift via organische mest en via kunstmest ingevoerd, en is de hoeveelheid beschikbare $\mathrm{N}$ (werkzame $\mathrm{N}$ ) berekend. Tevens is de adviesgift opgenomen, zodat selecties in de data gemaakt kunnen worden van bemestingen onder het advies, rondom het advies, of boven het advies.

\subsubsection{Beschikbare $\mathrm{N}$ en $\mathrm{N}$-advies}

\subsubsection{Beschikbare N}

Voor organische mest is bij de berekening van de hoeveelheid beschikbare $\mathrm{N}$ rekening gehouden met de mestsoort, toedieningswijze, toedieningstijdstip en stikstofopnameperiode van het gewas zoals beschreven in het Handboek Bodem en Bemesting (CBAV, 2019). Voor kunstmest is gerekend met een werking van $100 \%$. Bij snijmais en rijenbemesting met stikstof (zowel kunstmest als dierlijke mest) is gerekend met een werking van 125\% conform huidige bemestingsadvies (CBGV, 2019; www.bemestingsadvies.nl). Voor het overgrote deel van de gegevens over bemesting bij snijmais $(>90 \%)$ is bekend of deze volvelds of in de rij was toegediend. 


\subsubsection{N-Adviesgift}

De adviesgift is bepaald volgens de bemestingsrichtlijn gebaseerd op grondsoort, voorvrucht, Nmin voorafgaand aan de teelt en soms ook ras (CBAV, 2019; CBGV, 2019). De adviesgift is in veel gevallen tijdens het oorspronkelijke onderzoek bepaald en gerapporteerd, en overgenomen in de database. In een aantal gevallen is de adviesgift opnieuw berekend, o.a. wanneer het huidige advies in de tussentijd was aangepast.

Voor de gevallen in de database waarin geen adviesgift bekend was is deze op een andere wijze afgeleid. In enkele gevallen is hierbij uitgegaan van andere beschikbare informatie om de adviesgift te schatten, zoals vergelijkbare objecten in een proef of informatie rondom de optimale N-gift bij $\mathrm{N}$-trappenproeven in suikerbieten. Bij ontbrekende informatie over adviesgiften is echter meestal een standaardwaarde gebruikt op basis van een geschatte Nmin (Tabel 2.3). Het gebruik van een standaardwaarde is in de database aangegeven.

Zoals hierboven aangegeven is in de loop der jaren soms het bemestingsadvies veranderd. Dit was het geval voor zaaiuien. Bij zaaiuien geeft de adviesbasis van 2003 nog een advies voor een eenmalige gift van 100-120 kg/ha (Van Dijk, 2003). Rondom het voor zaaiuien opgezette bemestingsonderzoek in 2006 was er al discussie dat $120 \mathrm{~kg} / \mathrm{ha}$ te laag was en werd $150 \mathrm{~kg} / \mathrm{ha}$ gegeven. Het recente advies bedraagt $175 \mathrm{~kg} / \mathrm{ha}$, toe te dienen in delen (CBAV, 2019). Als standaardwaarde voor het advies bij zaaiuien wordt daarom $150 \mathrm{~kg} / \mathrm{ha}$ gebruikt t/m 2013, en voor latere jaren $175 \mathrm{~kg} / \mathrm{ha}$. Bij zaaiuien wordt Nmin niet in het advies meegenomen "omdat er geen goed verband bestaat tussen Nmin en de optimale gift" (Van Dijk, 2003).

Tabel 2.3 Gebruikte standaardwaarden voor N-bemestingsadvies wanneer deze niet bepaald waren (CBAV, 2019; snijmais: CBGV, 2019). De Nmin-waarde is een inschatting op basis van expert kennis (Schröder et al., 2004).

\begin{tabular}{|c|c|c|c|c|}
\hline Gewas & Grondsoort & Bemestingsrichtlijn & Nmin & $\begin{array}{c}\text { Standaard- } \\
\text { waarde (kg/ha) }\end{array}$ \\
\hline Consumptieaardappelen & klei/löss & $285-1,1 * N \min (0-60)$ & 30 & 252 \\
\hline Pootaardappelen & & $140-0,6 * N \min (0-60)$ & 30 & 122 \\
\hline Zetmeelaardappelen & zand/dal & $275-1,8 * \operatorname{Nmin}(0-30)$ & 20 & 239 \\
\hline Suikerbieten & zand/dal & Zand als klei, dal max 150 kg N/ha & 30 & 149 \\
\hline Zaai-uien & & $150 / 175$ & & $150 / 175^{a}$ \\
\hline \multirow[t]{2}{*}{ Wintertarwe } & klei/löss & $140-N \min (0-100)+90+40 / 80^{b}$ & 40 & $230 / 270$ \\
\hline & zand & $140-N \min (0-100)+90$ & 40 & 190 \\
\hline Zomergerst & zand & $120-\operatorname{Nmin}(0-60)$ & 30 & 90 \\
\hline Was- en winterpeen & & $100-N \min (0-60)+40$ & 30 & 120 \\
\hline \multirow[t]{3}{*}{ Graszaad (Engels raaigras) $^{d}$} & klei & Eerstejaars: 195 - Nmin(0-90) & 40 & 155 \\
\hline & zand & Eerstejaars: 195 - Nmin(0-60) & 30 & 165 \\
\hline & beide & Overjarig: 160 & 0 & 160 \\
\hline \multicolumn{5}{|l|}{ Snijmais en korrelmais e } \\
\hline Weinig mest in verleden & klei/löss & $205-N \min (0-30)-0$ & 20 & 185 \\
\hline \multirow[t]{2}{*}{ Veel mest in verleden } & klei & $190-N \min (0-30)-0$ & 40 & 150 \\
\hline & zand/dal/löss & $190-N \min (0-30)-20^{f}$ & 20 & $170 / 150^{f}$ \\
\hline
\end{tabular}

a 150 voor gegevens uit de jaren t/m 2013, 175 voor gegevens na 2013.

b De eerste gift is maximaal 100, de twee vervolggiften zijn ook maximale waarden, met voor de $3^{\text {e }}$ gift 40 voor voertarwe en 80 voor baktarwe.

c Dit is het gemiddelde van brouwgerst $(90-\mathrm{Nmin})$ en voergerst $(110-\mathrm{Nmin})$.

d In nazomer 0-30 kg/ha, afhankelijk van de stand van het gewas.

e Zie tekst voor verdere toelichting.

f Nalevering van $20 \mathrm{~kg} \mathrm{~N} /$ ha vanuit verplichte vanggewas voor teelten m.i.v. 2007, dus standaardwaarde 170 t/m 2006 , en 150 m.i.v. 2007. 
Voor consumptieaardappelen speelt vroegrijpheid van de rassen ook nog een rol, en wordt de adviesgift gekort met $20 \mathrm{~kg} \mathrm{~N} /$ ha per 0,5 lager vroegrijpheidscijfer dan 6,5 (Tabel 2.4). Voor de gevallen waarbij geen ras bekend was, was wel een Nmin bekend en is het advies volgens de algemene bemestingsrichtlijn berekend uit Tabel 2.3.

Tabel 2.4 Consumptieaardappelrassen met vroegrijpheidscijfer en gebruikte standaardwaarde voor het $N$-bemestingsadvies.

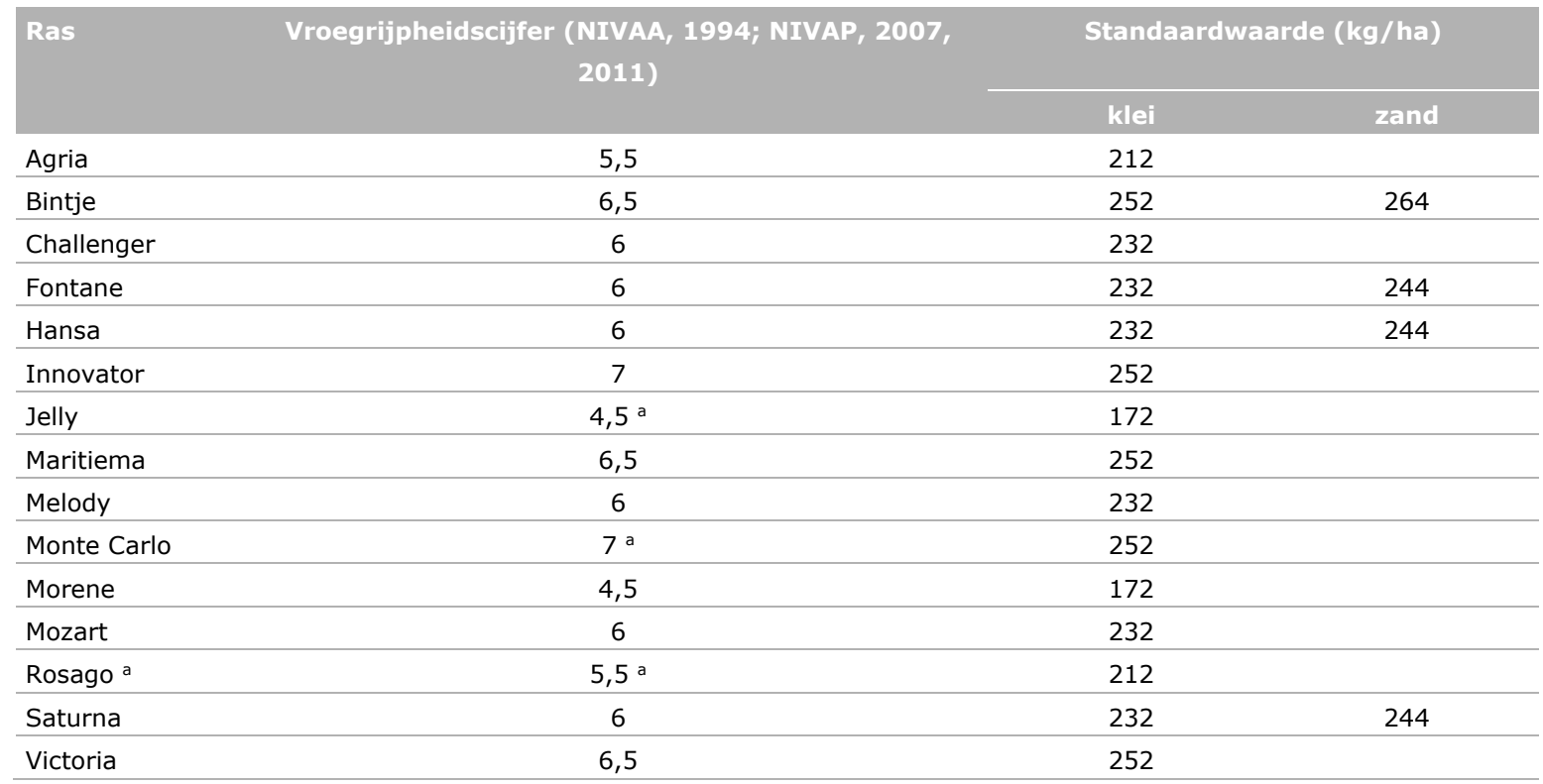

A Geen vroegrijpheidscijfer bekend; een waarde geschat op basis van tekstuele informatie over vroegheidsklasse. Rosago gelijk verondersteld aan Rosagold.

Ook bij zetmeelaardappelen is de adviesgift afhankelijk van het vroegrijpheidscijfer, maar zijn rasspecifieke N-bemestingsrichtlijnen gebruikt zoals gegeven door Avebe (2018) (Tabel 2.5). Daarnaast geeft Averis (2019) ook bemestingsinformatie die iets afwijkt van de informatie uit Tabel 2.5:

- Avarna: $140 \mathrm{~kg} \mathrm{~N} / \mathrm{ha}$ (dalgrond) - $150 \mathrm{~kg} \mathrm{~N} / \mathrm{ha}$ (zandgrond)

- Festien: $150 \mathrm{~kg} \mathrm{~N} / \mathrm{ha}$ (dalgrond) - $180 \mathrm{~kg} \mathrm{~N} / \mathrm{ha}$ (zandgrond)

- Seresta: $220 \mathrm{~kg} \mathrm{~N} / \mathrm{ha}$ (dalgrond) - $250 \mathrm{~kg} \mathrm{~N} / \mathrm{ha}$ (zandgrond)

Tabel 2.5 Adviezen voor N-bemesting van zetmeelaardappelrassen. De lage gift geldt voor de teelt op vochthoudende dalgronden, de hoge gift voor droge zandgronden (Avebe, 2018).

\begin{tabular}{cccc}
$140-180 \mathrm{~kg} \mathrm{~N}$ & $160-200 \mathrm{~kg} \mathrm{~N}$ & $180-220 \mathrm{~kg} \mathrm{~N}$ & $200-240 \mathrm{~kg} \mathrm{~N}$ \\
Axion & Festien & Altus & Seresta \\
\hline Avarna & Aventra & Supporter & Novano \\
\hline Sarion & Saprodi & Actaro & BMC \\
\hline & Merenco & Simphony & \\
\hline & Avito & Vermont &
\end{tabular}

Bij de zetmaalaardappelrassen die in de database voorkomen zijn voor de gevallen waarin geen $\mathrm{N}$-bemestingsadvies vanuit het onderzoek is gegeven de volgende standaardwaarden aangehouden, grotendeels gebaseerd op het gemiddelde van de informatie van Avebe (2018) en Averis (2019):

- 04-454 Sloots $160 \mathrm{~kg} \mathrm{~N} / \mathrm{ha}$

- Avarna: $140 \mathrm{~kg} \mathrm{~N} / \mathrm{ha}$ (dalgrond) - $180 \mathrm{~kg} \mathrm{~N} / \mathrm{ha}$ (zandgrond)

- Festien: $155 \mathrm{~kg} \mathrm{~N} / \mathrm{ha}$ (dalgrond) - $190 \mathrm{~kg} \mathrm{~N} / \mathrm{ha}$ (zandgrond)

- Seresta; $210 \mathrm{~kg} \mathrm{~N} / \mathrm{ha}$ (dalgrond) - $245 \mathrm{~kg} \mathrm{~N} / \mathrm{ha}$ (zandgrond)

- Valiant: $160 \mathrm{~kg} \mathrm{~N} / \mathrm{ha}$ 
Snijmais heeft een $\mathrm{N}$-bemestingsrichtlijn gebaseerd op mestgebruik in het verleden, en het advies omvat naast Nmin ook de verwachte $\mathrm{N}$-nalevering uit gewasresten van de voorvrucht en ondergewerkte groenbemesters (Tabel 2.6). Rondom het mestgebruik vermeldt het bemestingsadvies (CBGV, 2019; www.bemestingsadvies.nl):

"Veel mest betekent dat de voorgaande jaren minimaal $50 \mathrm{~m}^{3} \mathrm{drijfmest/ha/jaar}$ is toegediend. Weinig mest betekent dat de voorgaande jaren maximaal $10 \mathrm{~m}^{3}$ drijfmest/ha/jaar is toegediend. Ligt het niveau tussen 50 en $10 \mathrm{~m}^{3} \mathrm{drijfmest} / \mathrm{ha}$, dan kan men als advies een passende waarde tussen 180-Nmin en 205-Nmin kiezen."

Gegevens over mestgebruik in het verleden zijn niet meegenomen bij de dataverzameling. Bekend is dat bij de proeven op kleigrond in Wageningen en op het proefbedrijf in Lelystad weinig tot geen dierlijke mest is gebruikt. Verondersteld wordt dat er wel dierlijke mest in het verleden is gebruikt op alle andere kleilocaties, veelal praktijkbedrijven, en op de zandgrondlocaties. Hierbij wordt een gemiddeld mestgebruik van 35-40 $\mathrm{m}^{3}$ rundermest verondersteld, gebaseerd op de fosfaatnorm, wat uitkomt op een adviesniveau van 190 - Nmin - N-nalevering.

Verwachte $\mathrm{N}$-nalevering is afhankelijk van de voorvrucht en/of groenbemester, en deze informatie is veelal impliciet meegenomen bij de dataverzameling en verwerkt in de waarde van de adviesgift. Voor gevallen waarbij geen adviesgift en voorvrucht bekend is, wordt uitgegaan van mais als voorvrucht, gebaseerd op het gegeven dat $80 \%$ van het maisareaal in Nederland in continuteelt wordt geteeld (Holshof et al., 2019). Op zand- en lössgrond zal met ingang van najaar 2006 het verplichte vanggewas geteeld zijn. Er is uitgegaan van een gemiddelde nalevering van $20 \mathrm{~kg} \mathrm{~N} / \mathrm{ha}$ (www.bemestingsadvies.nl). Voor klei en veen wordt geen nalevering gerekend. Tabel 2.3 geeft de uiteindelijke standaardwaarden voor situaties waarin geen $\mathrm{N}$-bemestingsadvies bekend is.

Bij gegevens voor snijmais uit het Cultuur- en gebruikswaardeonderzoek (CGO) was de adviesgift niet gegeven; de proeven worden echter uitgevoerd "zoals een gemiddelde teler zijn gewas behandelt" (RVP-CSAR, 2019). Bij de data voor CGO mais is daarom verondersteld dat het bemestingsadvies gelijk was aan de uitgevoerde bemesting. Bij zandgrond was de bemesting soms vrij hoog, en is voor de inschatting van de adviesgift een maximum van $170 \mathrm{~kg} / \mathrm{ha}$ aangehouden voor de jaren 2006 en eerder, en met ingang van 2007 een maximum van $150 \mathrm{~kg} / \mathrm{ha}$.

Tabel 2.6 Advies voor de volveldse stikstofbemesting bij zaaien van maïs in $\mathrm{kg}$ stikstof per ha (CBGV, 2019).

\begin{tabular}{ll} 
Mestgebruik in het verleden & Advies bij zaaien \\
Veel mest & $180-\mathrm{Nmin}(0-30 \mathrm{~cm})-\mathrm{N}$-nalevering \\
\hline Weinig mest & $205-\mathrm{Nmin}(0-30 \mathrm{~cm})-\mathrm{N}$-nalevering \\
\hline
\end{tabular}

Voor peen en graszaad en vrijwel alle records van zomertarwe en zomergerst zijn de bemestingsadviezen al ingevuld bij de dataverzameling of eenvoudig af te leiden vanuit vergelijkbare objecten. Voor deze gewassen is daarom (vrijwel) geen gebruik gemaakt van standaardaard advieswaarden.

\subsubsection{Klassenindeling $\mathbf{N}$-beschikbaarheid ( $\mathbf{N}$-range)}

Voor stikstof wordt de verhouding tussen de hoeveelheid beschikbare $\mathrm{N}$ en de $\mathrm{N}$-adviesgift berekend om selecties te kunnen maken binnen de database. Hierbij wordt gekeken naar verschillende ranges van de hoeveelheid beschikbare $\mathrm{N}$ ten opzichte van de adviesgift, uitgedrukt als de hoeveelheid $\mathrm{N}$-beschikbaar gedeeld door het $\mathrm{N}$-advies (Tabel 2.7). Om het onderscheid tussen de ranges links en rechts duidelijk te houden is de waarde 1 ( $\mathrm{N}$-beschikbaarheid gelijk aan $\mathrm{N}$-advies) hierbij niet meegenomen. 
Tabel 2.7 Indeling van N-ranges op basis van de verhouding tussen de hoeveelheid N-beschikbaar en het $\mathrm{N}$-advies.

\begin{tabular}{ll} 
N-range & N-beschikbaar / N-adviesgift \\
Links & $0,5-0,999$ \\
\hline Rechts & $1,001-1,5$ \\
\hline Smal & $0,75-1,25$ \\
\hline Breed & $0,5-1,5$ \\
\hline
\end{tabular}

\subsubsection{N-gehalte in het gewas}

Het $\mathrm{N}$-gehalte in het geoogst product is bepaald in het lab. Regelmatig is alleen het eiwitgehalte bepaald, en is het $\mathrm{N}$-gehalte daaruit berekend volgens: $\mathrm{N}$-gehalte = eiwitgehalte/6,25.

\section{$2.4 \quad$ Fosfaat}

Voor de fosfaatbeschikbaarheid is zowel de fosfaattoestand van de bodem als de bemesting van belang. De fosfaattoestand wordt gegeven als $\mathrm{Pw}, \mathrm{P}-\mathrm{CaCl}_{2}$ en/of $\mathrm{P}-\mathrm{Al}$, en het fosfaatbemestingsadvies hangt af van de fosfaattoestand. Naast de fosfaattoestand zijn in de database de totale $\mathrm{P}_{2} \mathrm{O}_{5}$-gift via organische mest en via kunstmest ingevoerd, waarbij voor zowel organische mest als kunstmest is aangegeven of de bemesting volvelds of in rijen is toegediend.

\subsubsection{Fosfaattoestand en fosfaatbemestingsadvies}

\subsubsection{Fosfaattoestand}

De fosfaattoestand van de bodem is gegeven als $\mathrm{Pw}, \mathrm{P}-\mathrm{CaCl}_{2}$ en/of P-Al. Voor de situaties waarbij er geen $\mathrm{Pw}$-getal bekend was maar wel een $\mathrm{P}-\mathrm{CaCl}_{2}$ waarde, is het $\mathrm{Pw}$-getal berekend vanuit $\mathrm{P}-\mathrm{CaCl}_{2}$ volgens het verband beschreven door Oenema et al. (2016):

$$
\ln \left(P-\mathrm{CaCl}_{2}\right)=a+\mathrm{b}^{*} \mathrm{D} \wedge \mathrm{Pw} \text { dus: } \mathrm{PW}=\left(\mathrm{LOG}\left(\left(\mathrm{LN}\left(\mathrm{P}-\mathrm{CaCl}_{2}\right)-3\right) /-5,35\right)\right) / \mathrm{LOG}(0,98)
$$

Voor situaties waarbij alleen P-Al bekend was is het Pw-getal vanuit P-Al berekend volgens Oenema et al. (2016):

$$
\mathrm{PW}=(\mathrm{P}-\mathrm{Al}-11,2) / 0,885 \text { (Oenema et al., 2016). }
$$

Voor situaties waarbij zowel een $\mathrm{P}-\mathrm{CaCl}_{2}$ en $\mathrm{P}-\mathrm{Al}$ waarde bekend is maar geen $\mathrm{Pw}$, is de $\mathrm{Pw}$ berekend vanuit $\mathrm{P}-\mathrm{CaCl}_{2}$ zoals hierboven beschreven volgens het verband beschreven door Oenema et al. (2016). Hierbij had de Pw tevens vanuit P-Al berekend kunnen worden, om vervolgens het gemiddelde van beide berekeningen te gebruiken. Toepassing hiervan zou een beperkt effect hebben op de uiteindelijke selectie van data volgens P-klassen (zie paragraaf 2.4.1.3), en daarmee nauwelijks invloed op de uitkomsten. De berekening voor deze situaties waarbij zowel een $\mathrm{P}-\mathrm{CaCl}_{2}$ en $\mathrm{P}-\mathrm{Al}$ waarde bekend is maar geen $\mathrm{Pw}$ is daarom niet aangepast.

\subsubsection{Fosfaatbemestingsadvies}

Het fosfaatbemestingsadvies hangt af van de fosfaattoestand. Hierbij is onderscheid gemaakt tussen de akkerbouwgewassen en snijmais omdat daarvoor verschillende adviestabellen met verschillende grondslag worden gehanteerd. Voor de akkerbouwgewassen wordt het advies gebaseerd op het $\mathrm{PW}$-getal, voor snijmais op een combinatie van $\mathrm{P}-\mathrm{CaCl}_{2}$ (ofwel P-PAE) en P-Al.

Het fosfaatadvies bestaat uit een gewasgericht advies voor het behalen van een economisch optimale opbrengst en uit een bodemgericht advies voor handhaving van de streeftoestand van de bodem en eventuele reparatie daarvan. In het voorliggende rapport is uitgegaan van het gewasgerichte advies.

Voor de akkerbouwgewassen is het gewasgerichte fosfaatbemestingsadvies berekend vanuit de Pw volgens Tabel 2.8, rekening houdend met de grondsoort. Binnen de database is bij de 
akkerbouwgewassen vrijwel alle fosfaat volvelds toegediend. Eén keer bij peen en enkele keren bij consumptieaardappel is fosfaat toegediend in de rij; zowel kunstmest als organische mest. Het fosfaatbemestingsadvies geeft aan dat rijenbemesting een besparing tot $50 \%$ van de volveldsgift mogelijk maakt voor aardappelen op zandgronden met een lage fosfaattoestand. Rijenbemesting op zandgrond met lage fosfaattoestand komt echter niet voor in de database, zodat alle fosfaatbemesting voor de akkerbouwgewassen is vergeleken met het volveldse advies.

Tabel 2.8 Berekening van P-advies voor akkerbouwgewassen volgens het Handboek Bodem en Bemesting (CBAV, 2019a).

\begin{tabular}{lcr} 
Gewasgroep ${ }^{1}$ & Dekzand, dalgrond, rivierklei, löss & Zeeklei, zeezand \\
1: CA, UI & $218-3,3 * P w$ & $218-3,3 * P w$ \\
\hline 2: SB & $195-3,5 * P w$ & $187-3,71 * P w$ \\
\hline 3: ZG, WG, Peen & $167-3,67 * P w$ & $155-4,5 * P w$ \\
\hline 4: GZ, WT, ZT & $140-4 * P w$ & $100-4 * P w$ \\
\hline
\end{tabular}

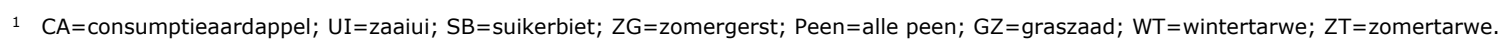
Pootaardappel en zetmeelaardappel als CA gedaan.

Voor snijmais is het fosfaatadvies in de loop van de tijd ingrijpend veranderd. Tot 2011 was het advies gebaseerd op het Pw-getal en de berekening voor gewasgroep 1 (zie Tabel 2.8), feitelijk conform het advies voor akkerbouwgewassen. Het huidige advies voor snijmais is in 2011 opgesteld en is niet meer gebaseerd op Pw, maar op $\mathrm{P}-\mathrm{CaCl}_{2}$ en P-Al (Bussink et al., 2011). Het huidig advies is daarnaast een rijenbemestingsadvies (CBGV, 2019; www.bemestingsadvies.nl). Dit advies onderscheidt twee tabellen: één voor een situatie zonder een volveldse gift met dierlijke mest (enkel rijenbemesting), en één voor een situatie met een volveldse gift van $60 \mathrm{~kg} \mathrm{P}_{2} \mathrm{O}_{5} /$ ha (voor gangbare praktijksituaties waarbij dierlijke mest volvelds is toegediend en meestal circa $60 \mathrm{~kg} \mathrm{P}_{2} \mathrm{O}_{5}$ per ha wordt gegeven). Binnen de database is echter een brede range aan volveldse giften aanwezig, terwijl het advies dus is gebaseerd op een volveldsgift van $60 \mathrm{~kg} \mathrm{P}_{2} \mathrm{O}_{5}$ per ha. Dit is als volgt opgelost: bij volveldsgiften $<30 \mathrm{~kg} \mathrm{P}_{2} \mathrm{O}_{5} /$ ha wordt de adviestabel voor situaties zonder volveldse gift gehanteerd bij volveldsgiften, bij volveldsgiften $\geq 30 \mathrm{~kg} \mathrm{P}_{2} \mathrm{O}_{5} /$ ha wordt de adviestabel voor situaties met een volveldsgift gehanteerd. Deze berekeningen zijn gedaan voor de data waarbij zowel $\mathrm{P}-\mathrm{CaCl}_{2}$ en $\mathrm{P}-\mathrm{Al}$ bekend waren. Wanneer niet allebei de fosfaattoestand-parameters bekend waren is het fosfaatbemestingsadvies berekend op basis van het $\mathrm{Pw}$-getal (gemeten of berekend vanuit $\mathrm{P}-\mathrm{CaCl}_{2}$ of $\mathrm{P}-\mathrm{Al}$ ) en de adviesberekening voor gewasgroep 1 (het advies van voor 2011).

Voor snijmais is een aantal extra berekening uitgevoerd om de fosfaatbemesting met het fosfaatbemestingsadvies te kunnen vergelijken. Het oude bemestingsadvies op basis van $\mathrm{Pw}$ is een volvelds advies. Uitgevoerde bemesting is omgerekend naar iets overeenkomstig volveldse toepassing door fosfaat die in rijen is toegediend dubbel te tellen. Het huidige bemestingsadvies is gebaseerd op al dan niet een volveldse basisgift (met dierlijke mest) en een rijenbemesting. Het totale advies is berekend als de som van de volveldse basisgift (volvelds; 0 of $60 \mathrm{~kg} \mathrm{P}_{2} \mathrm{O}_{5}$ ) en de adviesbemesting (rijentoediening). De uitgevoerde bemesting is omgerekend naar iets overeenkomstig het adviessysteem als de som van fosfaat toegediend via dierlijke mest (volvelds) en kunstmest (rijen). Indien dierlijke mest was toegediend in rijen is deze dubbel geteld; indien kunstmest volvelds was toegediend is deze voor de helft meegeteld.

In het bemestingsadvies voor akkerbouwgewassen wordt rivierklei samengenomen met dekzand, dalgrond en löss (zie Tabel 2.8). De database bevat gegevens uit onderzoek op rivierklei voor snijmais en consumptieaardappel (Bussink et al., 2011, 2014; Holshof et al., 2019). Dit zijn gewassen uit gewasgroep 1 waarbij in het fosfaatbemestingsadvies echter geen onderscheid gemaakt wordt naar grondsoort. Daarom is rivierklei verder gelabeld als klei.

\subsubsection{Klassenindeling fosfaat (P-klasse)}

Evenals bij stikstof is ook bij fosfaat een klassenindeling gemaakt voor de fosfaatbehoefte. Bij fosfaat wordt daarbij uitgegaan van een combinatie (matrix) van de fosfaattoestand van de bodem en de 
mate waarin de fosfaatbemesting afwijkt van het gewasgerichte bemestingsadvies gegeven de fosfaattoestand van de bodem.

De fosfaattoestand is ingedeeld in vier klassen, analoog aan Ehlert et al. $(2006,2009)$ en gebaseerd op Tabel 3.1 uit het Handboek Bodem en Bemesting (CBAV, 2019; Bijlage 1):

1. Laag: fosfaattoestand laag (Pw $\leq 20,5)$,

2. Midden: fosfaattoestand voldoende en ruim voldoende $(20,5<\mathrm{Pw} \leq 45,5)$,

3. Hoog: fosfaattoestand vrij hoog en hoog ( $P w>45,5)$,

4. Geen data (toestand onbekend).

Voor mais, waarbij de advisering is gebaseerd op $\mathrm{P}-\mathrm{CaCl}_{2}$ en $\mathrm{P}-\mathrm{Al}$ i.p.v. Pw, is ook de $\mathrm{P}$-toestandsklasse bepaald op basis van Pw (hetzij gemeten, hetzij berekend vanuit $\mathrm{P}-\mathrm{CaCl} 2$ en/of $\mathrm{P}-\mathrm{Al}$ ).

De toegediende fosfaatbemesting is ook ingedeeld in vier klassen, analoog aan Ehlert et al. (2006, 2009):

1. Laag: totale P-gift $<0,5 \times P$-adviesgift

2. Midden: $0,5 \times P$-adviesgift $\leq \mathrm{P}$-gift $\geq 2 \times P$-adviesgift

3. Hoog: >2xP-adviesgift,

4. Geen data (bemesting onbekend).

Voor de analyses worden analoog aan Ehlert et al., (2009) drie verschillende combinaties van P-toestand en P-bemesting aangehouden (Tabel 2.9).

Tabel 2.9 Indeling van P-klassen op basis van verschillende combinaties van P-toestandsklasse en P-bemestingsklasse, gebaseerd op Ehlert et al. (2006, 2009).

\begin{tabular}{ccc} 
P-klasse & P-toestand & P-bemesting \\
Midden & 2 & 2 \\
\hline Verbreed & 2 & geen selectie \\
\hline Alle data & geen selectie & geen selectie \\
\hline
\end{tabular}

\subsection{Standaard drogestofgehalten}

De drogestofgehalten in de database zijn weergegeven zoals ze bepaald zijn bij de oogst. Voor veel zaadgewassen (o.a. graan en graszaad) wordt de opbrengst meestal uitgedrukt bij een standaard drogestofgehalte. De versopbrengst en het $\mathrm{N}$ - en $\mathrm{P}$-gehalte in het verse product zijn daarom omgerekend naar een standaard drogestofgehalte (Tabel 2.10).

Tabel 2.10 Standaard drogestofgehalten zoals gehanteerd voor verschillende gewassen en gewasresten ter bepaling van versopbrengst en $N$ - en P-gehalte.

\begin{tabular}{llr} 
Gewas & $\begin{array}{c}\text { Drogestofigehalte } \\
\text { hoofdproduct }\end{array}$ & Drogestofgehalte \\
Gerst - brouw & 85 & 85 \\
\hline Gerst - winter & 85 & 85 \\
\hline Gerst -zomer & 85 & 85 \\
\hline Tarwe - winter & 85 & 85 \\
\hline Tarwe - zomer & 85 & 85 \\
\hline Snijmais & 35 & - \\
\hline Korrelmais & 74 & 30 \\
\hline Graszaad & 90 & 90
\end{tabular}




\subsection{Bewerking en analyse van de data}

De data zijn gecontroleerd op onderlinge consistentie tussen drogestofgehalte, versopbrengst en drogestofopbrengst. Kleine afwijkingen zijn hierbij te verwachten aangezien zowel versopbrengst als drogestofgehalte en drogestofopbrengst gemiddelden per object zijn. Alleen bij snijmais kwamen soms relatief grote verschillen voor, en zijn gegevens uitgesloten waarbij de berekende drogestofopbrengst meer dan een ton afweek van de ingevoerde drogestofopbrengst. Dit betrof 33 gevallen van de ruim 16 duizend snijmaisgegevens. Overzichten van aantallen gegevens per gewas worden gegeven in Hoofdstuk 3.

Biologische teelten worden in de analyses niet specifiek onderscheiden. Data van biologische teelten worden gewoon meegenomen, en op basis van P-klasse of $\mathrm{N}$-range al dan niet geselecteerd. Wel worden in figuren van geselecteerde data de punten van biologische teelt in een andere kleur weergegeven.

Analyses worden uitgevoerd met behulp van het programma Genstat. Het N-gehalte (\%) en P-gehalte (\%) in het verse product en de versopbrengst (ton/ha) worden bekeken voor kleigrond, zandgrond en de combinatie van deze twee grondsoorten bij in totaal twaalf combinaties van N-range (links, rechts, smal, breed) en P-klasse (midden, verbreed, alle data). Voor iedere selectie wordt de mediane waarde berekend, het $25 \%$ en $75 \%$ kwantiel, de minimum en maximum waarde en het aantal waarnemingen. Tevens wordt geanalyseerd of er een significant effect $(p<0,05)$ is van grondsoort of opbrengstniveau op het $\mathrm{N}$ - of $\mathrm{P}$-gehalte. Indien er sprake is van een significant effect van opbrengstniveau, wordt via lineaire regressieanalyse de omvang van het effect bepaald (helling regressielijn).

Uit de resultaten van de analyses worden vervolgens de te hanteren $\mathrm{N}$ - en P-gehalten geselecteerd volgens een aantal criteria:

- Een minimum van 10 waarnemingen.

- Voor zowel $\mathrm{N}$ - als P-gehalte dezelfde combinatie van N-range en P-klasse.

- Bij voorkeur de combinatie van N-range 'smal' en P-klasse 'midden' om zo dicht mogelijk bij gegevens passend bij de bemestingsadviezen te blijven.

- Bij onvoldoende waarnemingen in de combinatie van N-range 'smal' en P-klasse 'midden' kan een andere N-range en/of P-klasse gekozen worden. Aangezien N een sterker effect heeft op het gewas dan $\mathrm{P}$ wordt het onderliggende aantal waarnemingen eerst vergroot door te kiezen voor de combinatie N-range 'smal' en P-klasse 'verbreed', en daarna pas voor combinaties met N-range 'breed' of P-klasse 'alle data'.

Het verschil tussen de $\mathrm{N}$-ranges 'links' en 'rechts' wordt gebruikt om te bepalen of er een effect van $\mathrm{N}$-bemesting is op het gehalte of de opbrengst. Wanneer links en rechts duidelijk verschillen is er een effect van $\mathrm{N}$-bemesting op gehalte of opbrengst en dient de dataset ingeperkt te blijven tot een smalle range rondom het advies.

Bij de selecties wordt het gehele overzicht van uitkomsten meegenomen om te zien of er geen grote verschillen zijn in gehalten tussen verschillende combinaties van $\mathrm{N}$-range en P-klasse. Als er duidelijke verschillen zijn dient de grootte van de dataset en de diversiteit van databronnen, locaties en jaren meegewogen te worden bij de keuze voor te hanteren $\mathrm{N}$ - en P-gehalten.

Onderscheid tussen de grondsoorten klei en zand wordt gemaakt indien de gehalten significant verschillend zijn, en er ook 'relevante verschillen' zijn in gehalte tussen de grondsoorten (verschil $>5 \%$ ).

Significante effecten van opbrengstniveau op de gehalten komen uit de regressieanalyse. Deze relaties worden vervolgens beoordeeld op correlatiecoëfficiënt en relevantie, en worden niet meegenomen wanneer deze worden bepaald door slechts enkele datapunten of wanneer er sprake is van veel variatie en een lage correlatiecoëfficiënt. 


\section{Resultaten}

\subsection{Verzamelde data}

Overzichten van het aantal waarnemingen van het $\mathrm{N}$-gehalte en P-gehalte worden gegeven in Tabellen 3.1 en 3.2. Hierbij is per gewas en grondsoortcombinatie het totale aantal waarnemingen gegeven, en het aantal wanneer een selectie wordt gemaakt voor situaties waarbij de bemesting dichtbij het bemestingsadvies lag. Voor beide situaties is ook aangegeven uit welke periode de gegevens afkomstig zijn (als som per decennium). Een overzicht van het totaal aantal waarnemingen voor de individuele jaren vanaf 1990 wordt gegeven in Bijlagen 3 en 4. Over het algemeen zijn de gegevens redelijk verdeeld over de periode 1990-2018, met uitzondering van graszaad (data uit jaren 2000) en wintertarwe-stro en korrelmais (beide met data uit jaren '90). Voor het N-gehalte zijn meer gegevens beschikbaar dan voor het P-gehalte.

De selectie op situaties waarbij de bemesting dichtbij het bemestingsadvies lag gaf bij de meeste gewassen een sterke reductie van het aantal waarnemingen, in sommige gevallen resteerde een zeer laag aantal waarnemingen. Als meer gegevens nodig zijn voor het bepalen van de $\mathrm{N}$ - en P-gehalten kan een andere selectie worden toegepast: van N-range 'smal' naar 'breed', en van P-klasse 'midden' naar 'verbreed' naar 'alle data' (Tabel 3.3).

Graszaad is in de analyse verder niet meer meegenomen. De gegevens over gehalten betroffen het totaal van zaad en hooi en waren niet beschikbaar voor de afzonderlijke onderdelen. Het totaal aantal waarnemingen van het N-gehalte bedroeg 146 voor klei en 21 voor zand, alles uit de periode 2000-09. Er waren geen gegevens beschikbaar voor het P-gehalte. 


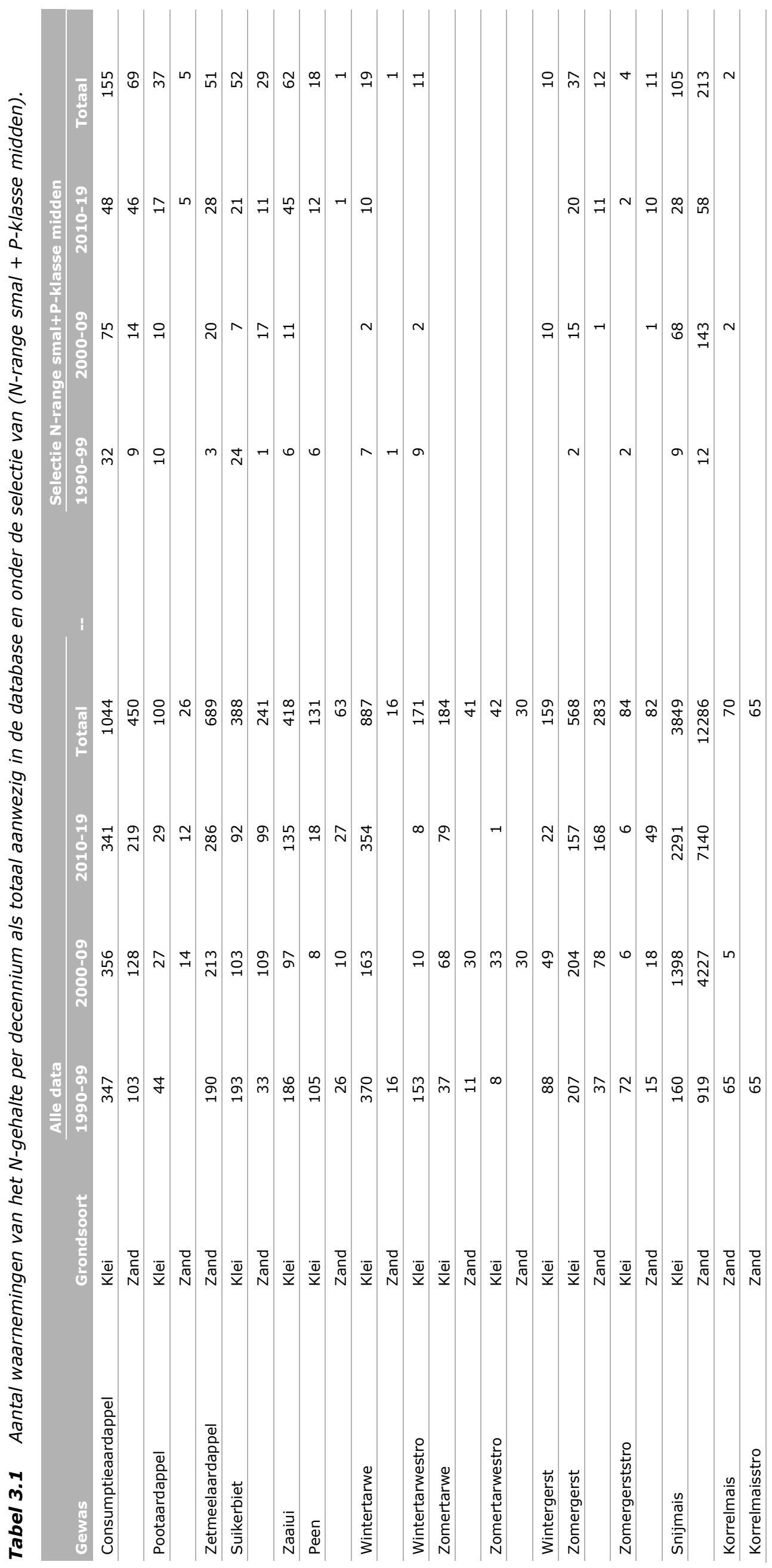




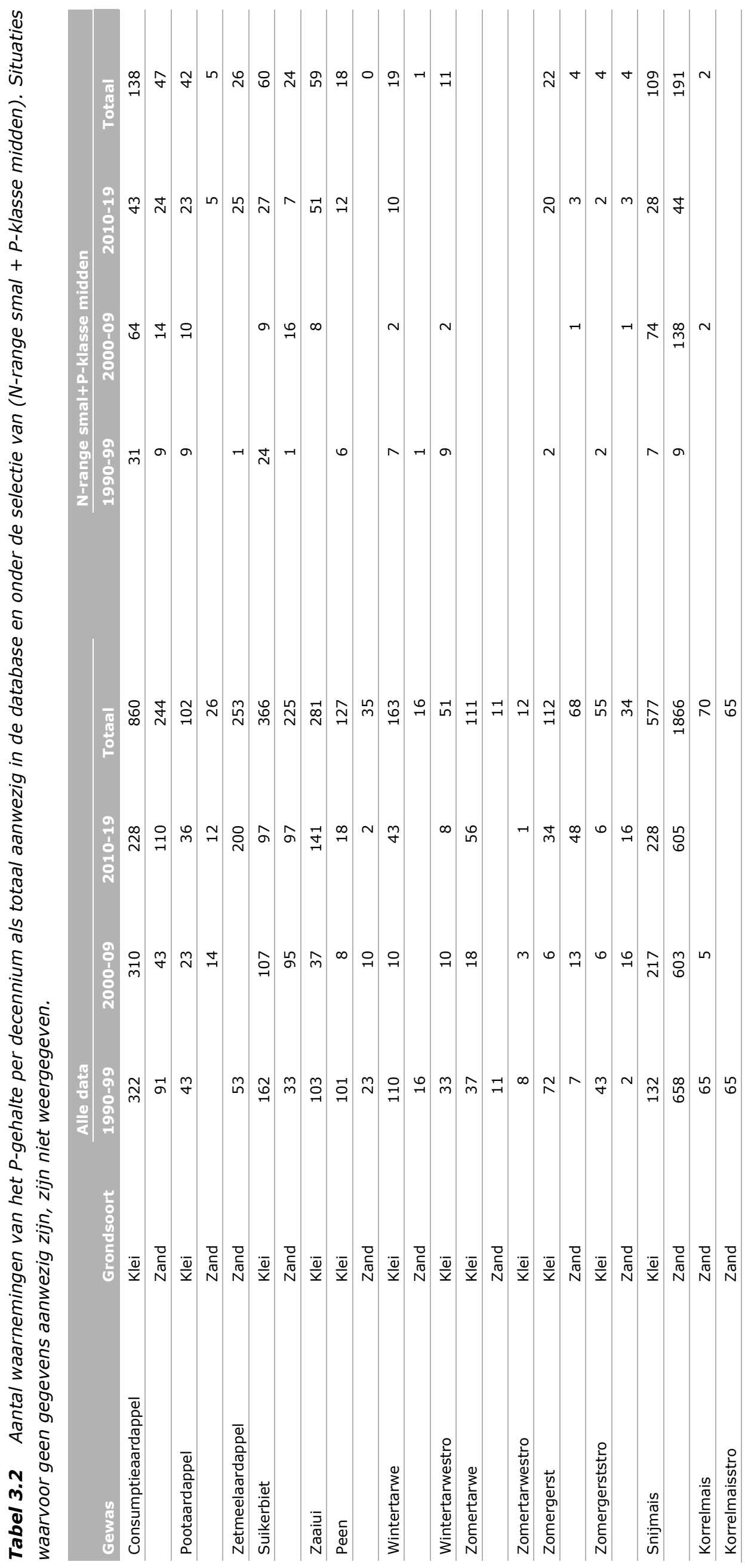




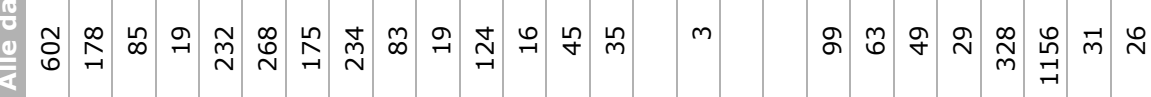

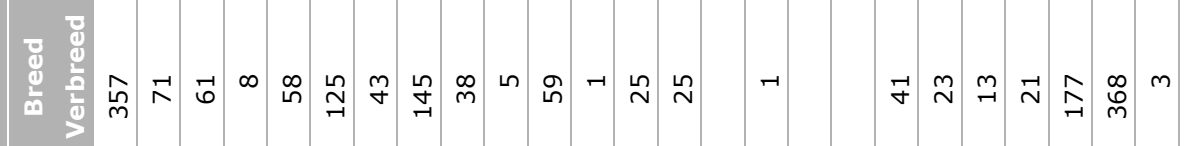

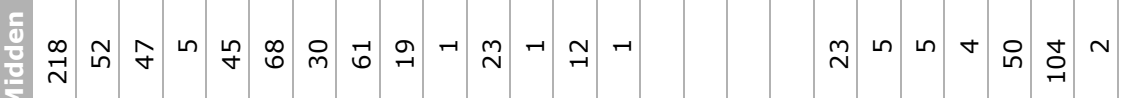

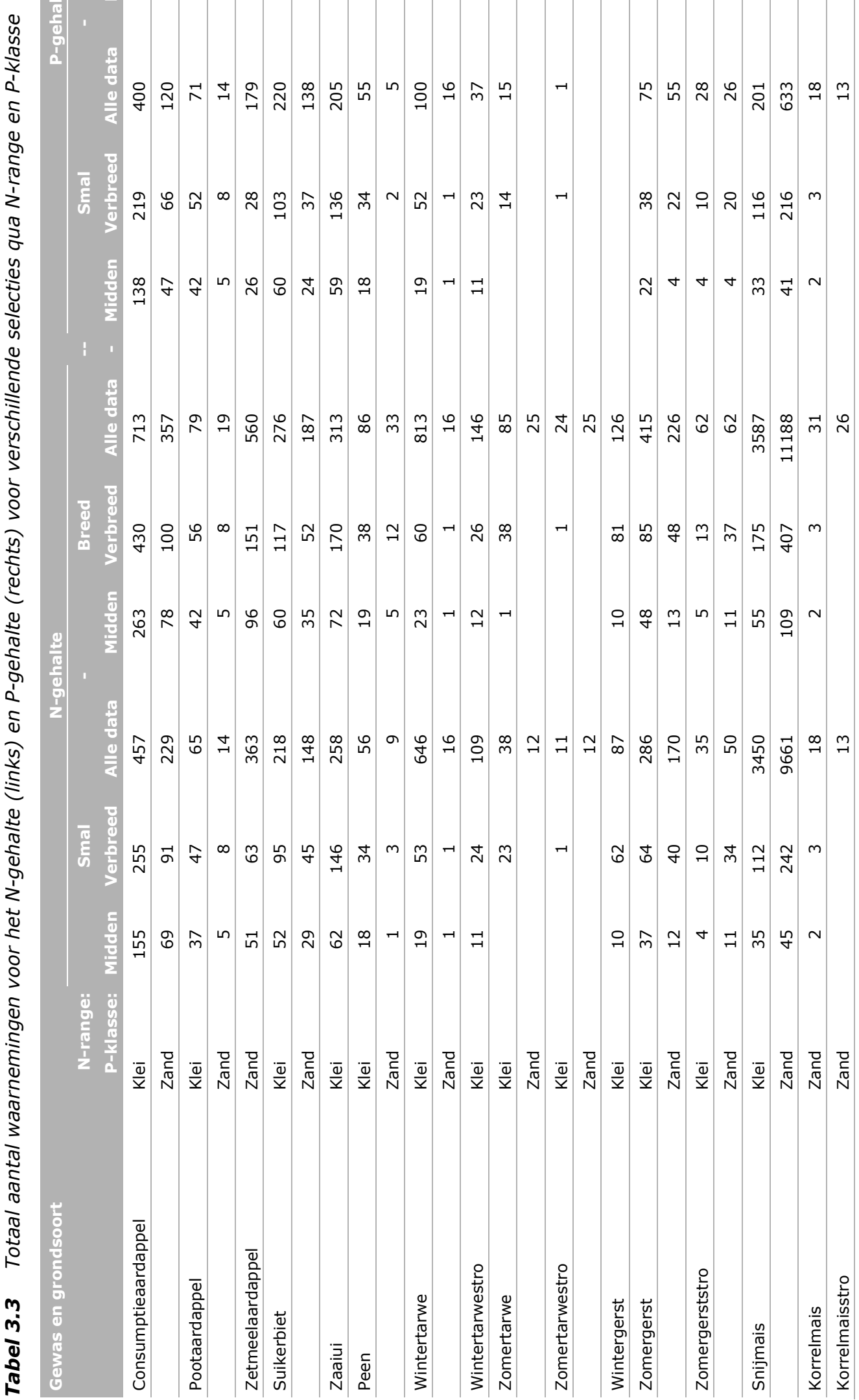




\subsection{N- en P-gehalten per gewas}

De spreiding in $\mathrm{N}$ - en P-gehalten en opbrengst bij verschillende selecties op N-range en P-klasse is per gewas weergegeven in boxplot figuren. Figuur 3.1 geeft daarvan een voorbeeld voor consumptieaardappelen bij P-klasse midden. Te zien is dat het $\mathrm{N}$-gehalte hoger is bij N-range rechts vergeleken met $\mathrm{N}$-range links (zie Tabel 2.7 voor de beschrijving van de N-ranges). Hieruit wordt geconcludeerd dat $\mathrm{N}$-bemesting effect heeft op het $\mathrm{N}$-gehalte, en dat daarom beter gegevens dichtbij het bemestingsadvies gehanteerd kunnen worden voor bepaling van het $\mathrm{N}$-gehalte. Daarom worden de resultaten van de $\mathrm{N}$-range smal gebruikt. Het aantal waarnemingen $(n)$ is bij deze selectie voor zowel klei als zand voldoende.
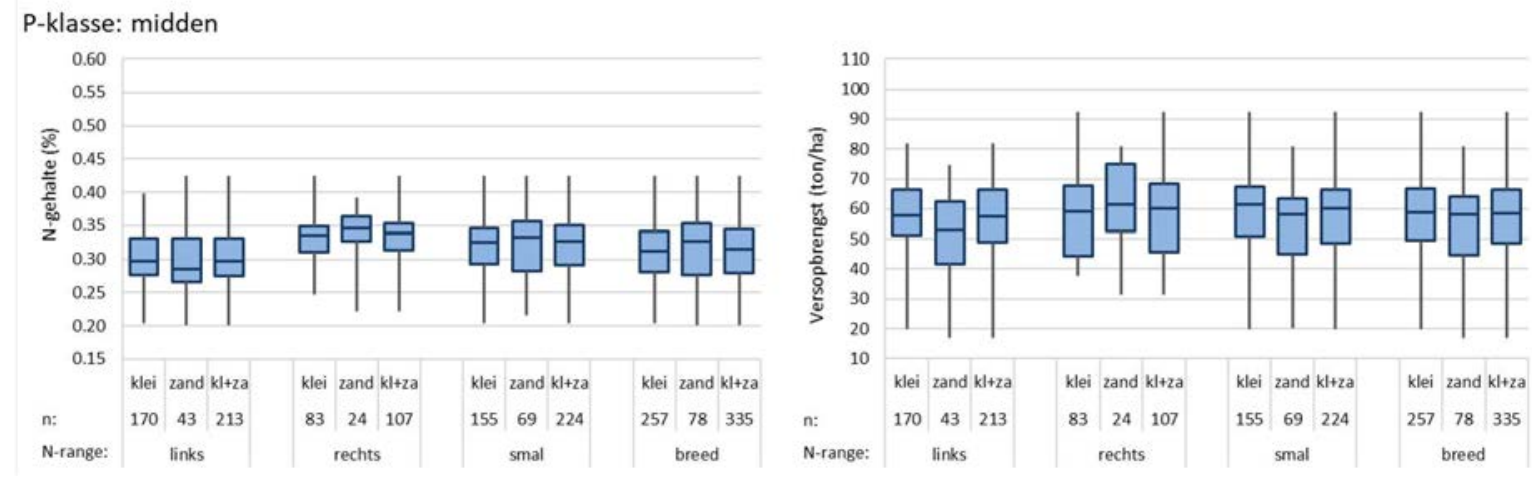

Figuur 3.1 Voorbeeld van boxplot figuren die de spreiding en mediane waarde weergeven voor verschillende selecties op $\mathrm{N}$-klasse bij P-klasse midden. Zie Bijlage 5 voor figuren voor alle gewassen en P-klassen.

Voor alle gewassen en P-klassen zijn boxplotfiguren gegeven in Bijlage 5. Bijlage 6 geeft een overzicht van de uitkomsten, waarbij voor de zes combinaties van N-range en P-klasse de mediane waarden zijn gegeven voor $\mathrm{N}$-gehalte, versopbrengst, aantal waarnemingen en het verband tussen gehalte en versopbrengst, indien dat statistisch significant was. In Bijlage 7 is dit gedaan voor het P-gehalte. In deze bijlagen zijn tevens de geselecteerde sets aangegeven waarop de mediane waarde voor N- en P-gehalte zijn gebaseerd, gebaseerd op de selectiecriteria zoals beschreven in paragraaf 2.6. Deze geselecteerde waarden zijn voor het $\mathrm{N}$-gehalte gegeven in Tabel 3.4 en voor het P-gehalte in Tabel 3.5.

Tabel 3.4 Geselecteerde mediane waarden voor het $\mathrm{N}$-gehalte (\%) in vers product. Een * bij de gewasnaam betekent een significant effect van opbrengstniveau op het $N$-gehalte (zie hoofdstuk 3.3).

\begin{tabular}{|c|c|c|c|c|c|}
\hline Gewas & Code & N-range & P-klasse & Grondsoort ${ }^{1}$ & N-gehalte $(\%)$ \\
\hline Consumptieaardappel & $\mathrm{CA}$ & smal & midden & klei en zand & 0,33 \\
\hline Pootaardappel & PA & smal & midden & klei en zand & 0,25 \\
\hline Suikerbiet * & SB & smal & midden & klei en zand & 0,115 \\
\hline Zaaiuien * & UI & smal & midden & klei & 0,18 \\
\hline Wintertarwe-stro & WTs & smal & verbreed & klei & 0,37 \\
\hline Zomertarwe & $\mathrm{ZT}$ & smal & verbreed & klei & 1,66 \\
\hline Zomertarwe-stro & ZTs & breed & alle data & klei en zand & 0,56 \\
\hline Wintergerst & WG & smal & alle data & klei en zand & 1,60 \\
\hline \multirow[t]{2}{*}{ Peen } & PE & breed & alle data & klei & 0,11 \\
\hline & & & & zand & 0,13 \\
\hline Snijmais * & SM & smal & midden & klei en zand & 0,41 \\
\hline Korrelmais * & KM & breed & alle data & zand & 1,15 \\
\hline Korrelmais-stro & KMs & breed & alle data & zand & 0,22 \\
\hline
\end{tabular}

\footnotetext{
1 'klei en zand' betekent dat er geen statisch significant verschil is tussen deze grondsoorten.
} 
Tabel 3.5 Geselecteerde mediane warden voor het P-gehalte (\%) in vers product. Een * bij de gewasnaam betekent een significant effect van opbrengstniveau op het P-gehalte (zie hoofdstuk 3.3).

\begin{tabular}{|c|c|c|c|c|c|}
\hline Gewas & Code & N-range & P-klasse & Grondsoort & P-gehalte $(\%)^{1}$ \\
\hline Consumptieaardappel & CA & smal & midden & klei en zand & 0,041 \\
\hline Pootaardappel * & PA & smal & midden & klei en zand & 0,050 \\
\hline Suikerbiet * & SB & smal & midden & klei en zand & 0,032 \\
\hline Zaaiuien * & UI & smal & midden & klei & 0,035 \\
\hline Wintertarwe-stro & WTs & smal & verbreed & klei & 0,051 \\
\hline Zomertarwe & $\mathrm{ZT}$ & smal & verbreed & klei & 0,320 \\
\hline Zomertarwe-stro & ZTs & & & & - \\
\hline Wintergerst & WG & & & & - \\
\hline Peen & & & & zand & 0,032 \\
\hline \multirow[t]{2}{*}{ Snijmais } & SM & smal & midden & klei & 0,072 \\
\hline & & & & zand & 0,063 \\
\hline Korrelmais * & $\mathrm{KM}$ & breed & alle data & zand & 0,244 \\
\hline Korrelmais-stro & KMs & breed & alle data & zand & 0,023 \\
\hline
\end{tabular}

1 Voor omrekening naar $\mathrm{P}_{2} \mathrm{O}_{5}$ vermenigvuldigen met 2,29. 


\subsection{Effect van opbrengstniveau op $\mathrm{N}$ - en P-gehalte}

Het effect van het opbrengstniveau op het $\mathrm{N}$ - of P-gehalte volgt uit de regressieanalyse (zie bijlagen 6 en 7), en kan visueel beoordeeld worden via figuren van de relatie tussen gehalte en opbrengst (zie Bijlage 8). Een voorbeeld van zo'n figuur wordt gegeven in Figuur 3.2 voor het N-gehalte bij consumptieaardappelen. Binnen de figuur is onderscheid gemaakt naar grondsoort (klei en zand) en naar teeltwijze (gangbaar en biologisch). Binnen de analyses is alleen een mogelijk effect van grondsoort bekeken, en is geen onderscheid gemaakt naar teeltwijze. Bij consumptieaardappelen en de geselecteerde $\mathrm{N}$-range en P-klasse is er geen sprake van een verband tussen $\mathrm{N}$-gehalte en opbrengst.

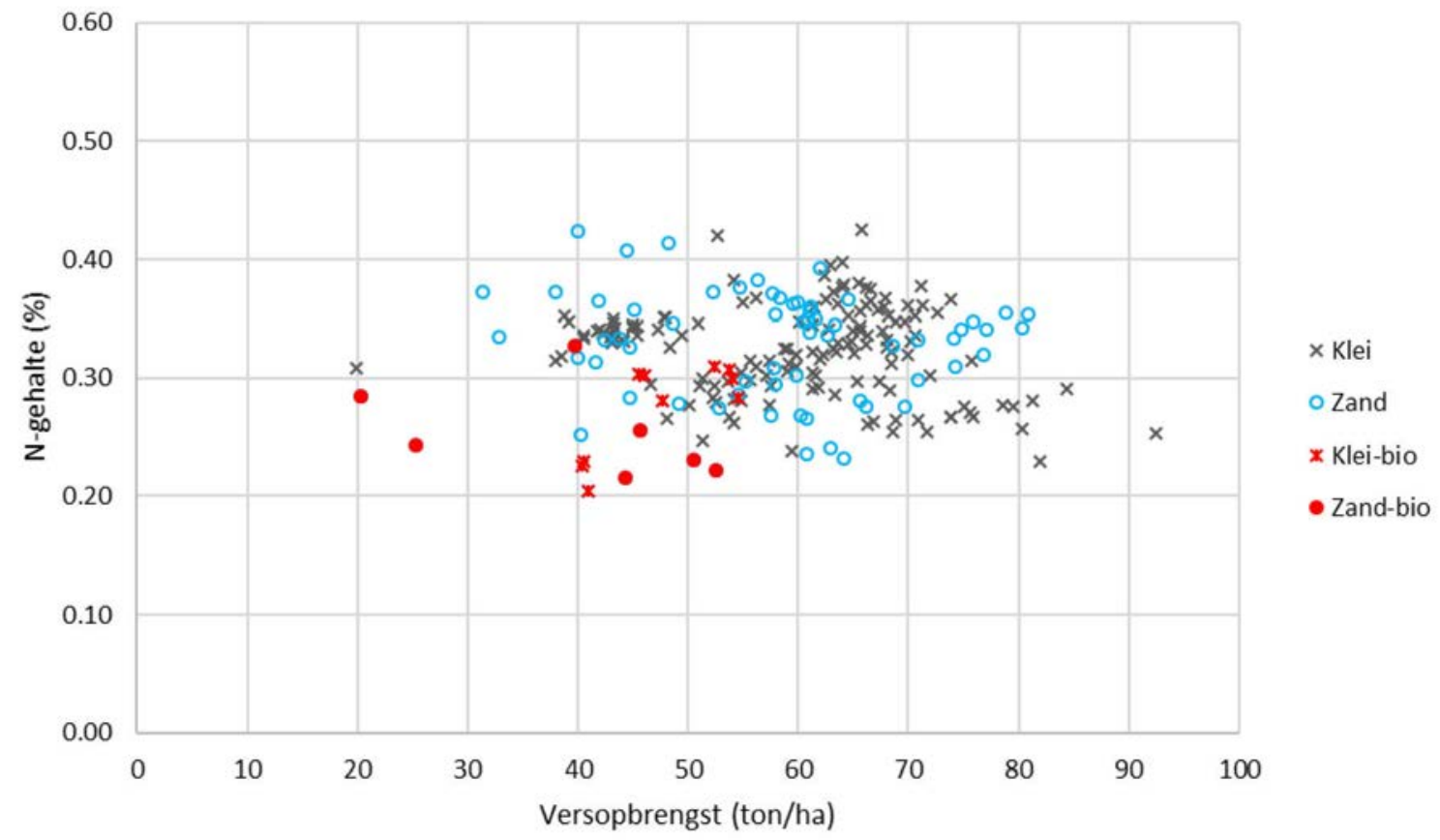

Figuur 3.2 Verband tussen het $N$-gehalte en de versopbrengst bij consumptieaardappelen voor de selectie op N-range smal en P-klasse midden (zie Bijlage 8 voor P-gehalte en andere gewassen).

In tabellen in de voorgaande paragraaf is met een * aangegeven bij welke gewassen een significante en mogelijk relevante relatie tussen gehalte en opbrengst is gevonden. Tabel 3.6 en Tabel 3.7 geven bij die gewassen voor $\mathrm{N}$ en $\mathrm{P}$ de relatie tussen opbrengstniveau en gehalte, en in Tabel 3.8 en Tabel 3.9 wordt het effect beschreven van een vast gehalte of een opbrengst-afhankelijk gehalte op de $\mathrm{N}$ - en P-afvoer bij een opbrengstverhoging van $25 \%$ ten opzichte van de huidige mediane waarde voor de opbrengst.

Voor $\mathrm{N}$ zijn alle relaties (voor zover er een significant verband is) negatief: bij toenemend opbrengstniveau daalt het $\mathrm{N}$-gehalte. De $\mathrm{N}$-afvoer is altijd hoger bij hogere opbrengst, maar dit effect wordt gedempt doordat het $\mathrm{N}$-gehalte daalt bij toenemende opbrengst. Deze demping is in relatieve zin het grootst bij zaaiui, snijmais en wintertarwe op klei. Bij snijmais is er wel sprake van veel spreiding (Bijlage 8) en is de correlatie tussen N-gehalte en opbrengst zwak (Tabel 3.6).

Bij $\mathrm{P}$ zijn de relaties tussen P-gehalte en opbrengst ook voor een groot deel negatief, behalve bij pootaardappel en korrelmais waar het gehalte toeneemt bij toenemende opbrengst. De P-afvoer is altijd hoger bij hogere opbrengst, en dit effect wordt gedempt wanneer het P-gehalte daalt bij toenemende opbrengst. Voor suikerbiet op zand betekent dit dat vanwege het opbrengst-afhankelijke P-gehalte de P-afvoer nauwelijks stijgt bij toenemende opbrengst. Voor de andere gewassen in Tabel 3.7 en Tabel 3.9 met een dalend P-gehalte bij toenemende opbrengst is dit dempende effect minder sterk en geeft toenemende opbrengst wel een hogere P-afvoer. 
Tabel 3.6 Relatie tussen opbrengstniveau en het $N$-gehalte volgens: gehalte $=$ constante + (helling $x$ opbrengst). Getoonde waarden voor $N(\%)$ en opbrengst ( $t / h a)$ betreffen mediane waarden.

\begin{tabular}{lllllllllll} 
Gewas & Code & N-range & P-klasse & Grondsoort & N $(\%)$ & Opbrengst & Constante & Helling & $\mathbb{R}^{2}$ \\
Suikerbiet & SB & smal & midden & klei en zand & 0,115 & 80,4 & 0,1747 & $-0,000649$ & 0,23 \\
\hline Zaaiui & UI & smal & midden & klei & 0,18 & 70,4 & 0,299 & $-0,001571$ & 0,44 \\
\hline Wintertarwe & WT & smal & alle data & klei & 1,62 & 11,1 & 2,147 & $-0,04617$ & 0,21 \\
\hline & & & & zand & 1,71 & 6,4 & 2,0476 & $-0,04617$ & 0,21 \\
\hline Snijmais & SM & \multirow{2}{*}{ smal } & \multirow{2}{*}{ midden } & klei & 0,41 & 47,7 & 0,4792 & $-0,001789$ & 0,09 \\
\hline & & & & zand & 0,41 & 44,3 & 0,50559 & $-0,001789$ & 0,09 \\
\hline Korrelmais & KM & breed & \multirow{2}{*}{ alle data } & zand & 1,15 & 10,8 & 1,394 & $-0,02164$ & 0,27 \\
\hline
\end{tabular}

Tabel 3.7 Relatie tussen opbrengstniveau en het P-gehalte volgens: gehalte $=$ constante + (helling $x$ opbrengst). Getoonde waarden voor $P(\%)$ en opbrengst ( $t /$ ha) betreffen mediane waarden.

\begin{tabular}{lllllllllll} 
Gewas & Code & N-range & P-klasse & Grondsoort & P $(\%)$ & Opbrengst & Constante & Helling & $R^{2}$ \\
Pootaardappel & PA & smal & midden & klei en zand & 0,050 & 40,6 & 0,02807 & 0,00048 & 0,17 \\
\hline Suikerbiet & SB & smal & midden & klei & 0,032 & 81,5 & 0,04476 & $-0,0001426$ & 0,19 \\
\hline & & & & zand & 0,032 & 83,0 & 0,0410 & $-0,0001426$ & 0,19 \\
\hline Zaaiui & UI & smal & midden & klei & 0,035 & 70,7 & 0,05584 & $-0,000274$ & 0,37 \\
\hline Wintertarwe & WT & smal & alle data & klei en zand & 0,306 & 9,5 & 0,3556 & $-0,00534$ & 0,13 \\
\hline Zomergerst & ZG & smal & verbreed & klei en zand & 0,315 & 7,4 & 0,3925 & $-0,01064$ & 0,31 \\
\hline Korrelmais & KM & breed & alle data & zand & 0,244 & 10,8 & 0,1141 & 0,01207 & 0,40 \\
\hline
\end{tabular}

Tabel 3.8 N-afvoer ( $\mathrm{kg} / \mathrm{ha}$ ) bij huidige opbrengst $(Y)$ en huidig gehalte ([N]), en bij een $25 \%$ hogere opbrengst bij gelijkblijvend $N$-gehalte en bij een aangepast $N$-gehalte volgens de regressielijn uit Tabel 3.6. Het verschil geeft het gebruik van opbrengstafhankelijk gehalte ten opzichte van een vast gehalte weer.

\begin{tabular}{|c|c|c|c|c|c|c|c|c|c|}
\hline \multirow[b]{2}{*}{ Gewas } & \multirow[b]{2}{*}{ Code } & \multirow[b]{2}{*}{$\mathrm{N}$-range } & \multirow[b]{2}{*}{ P-klasse } & \multirow[b]{2}{*}{ Grondsoort } & \multirow{2}{*}{$\begin{array}{l}\text { huidige Y } \\
\text { huidig [N] }\end{array}$} & \multicolumn{2}{|c|}{$25 \%$ hogere $Y$. } & \multicolumn{2}{|c|}{ Verschil } \\
\hline & & & & & & Huidig [N] & [N] uit regressie & Relatief & Absoluut \\
\hline Suikerbiet & SB & smal & midden & klei en zand & 92 & 116 & 110 & 0,95 & -5 \\
\hline Zaaiui & UI & smal & midden & klei & 125 & 157 & 141 & 0,90 & -15 \\
\hline \multirow[t]{2}{*}{ Wintertarwe } & WT & smal & alle data & klei & 180 & 225 & 209 & 0,93 & -16 \\
\hline & & & & zand & 109 & 136 & 134 & 0,98 & -2 \\
\hline \multirow[t]{2}{*}{ Snijmais } & SM & smal & midden & klei & 198 & 247 & 222 & 0,90 & -25 \\
\hline & & & & zand & 184 & 229 & 225 & 0,98 & -4 \\
\hline Korrelmais & KM & breed & alle data & zand & 123 & 154 & 148 & 0,96 & -6 \\
\hline
\end{tabular}

Tabel $3.9 P$-afvoer $(\mathrm{kg} / \mathrm{ha}$ ) bij huidige opbrengst $(Y)$ en huidig gehalte $([P])$, en bij een $25 \%$ hogere opbrengst bij gelijkblijvend P-gehalte en bij een aangepast P-gehalte volgens de regressielijn uit Tabel 3.7. Het verschil geeft het gebruik van opbrengstafhankelijk gehalte ten opzichte van een vast gehalte weer.

\begin{tabular}{|c|c|c|c|c|c|c|c|c|c|}
\hline \multirow[b]{2}{*}{ Gewas } & \multirow[b]{2}{*}{ Code } & \multirow[b]{2}{*}{$\mathrm{N}$-range } & \multirow[b]{2}{*}{ P-klasse } & \multirow[b]{2}{*}{ Grondsoort } & \multirow{2}{*}{$\begin{array}{l}\text { Huidige Y } \\
\text { huidig [P] }\end{array}$} & \multicolumn{2}{|c|}{$25 \%$ hogere $Y$} & \multicolumn{2}{|c|}{ Verschil } \\
\hline & & & & & & huidig $[P]$ & [P] uit regressie & Relatief & Absoluut \\
\hline Pootaardappel & PA & smal & midden & klei en zand & 20 & 25 & 27 & 1,05 & 1 \\
\hline \multirow[t]{2}{*}{ Suikerbiet } & SB & smal & midden & klei & 26 & 32 & 31 & 0,95 & -2 \\
\hline & & & & zand & 26 & 33 & 27 & 0,82 & -6 \\
\hline Zaaiui & UI & smal & midden & klei & 25 & 31 & 28 & 0,91 & -3 \\
\hline Wintertarwe & WT & smal & alle data & klei en zand & 29 & 36 & 35 & 0,95 & -2 \\
\hline Zomergerst & ZG & smal & verbreed & klei en zand & 23 & 29 & 27 & 0,94 & -2 \\
\hline Korrelmais & $\mathrm{KM}$ & breed & alle data & zand & 26 & 33 & 37 & 1,13 & 4 \\
\hline
\end{tabular}




\subsection{Effect van consumptieaardappelras op $\mathrm{N}$ - en P-gehalte}

Aardappelrassen verschillen van elkaar in $\mathrm{N}$-behoefte en zijn ingedeeld in de $\mathrm{N}$ gebruiksnormcategorieën lage norm en hoge norm overeenkomstig Tabel 1a van het Mestbeleid 2019-2021 (RVO, 2019). Niet genoemde rassen vallen in de standaard norm. Rassen worden vergeleken na selectie op $\mathrm{N}$-range smal en P-klasse midden om verschillen bij bemesting volgens het advies te kunnen zien. Figuur 3.3 geeft voor kleigrond en zandgrond de N- en P-gehalten van individuele rassen. Niet alle gemiddelden zijn even betrouwbaar, aangezien er voor sommige rassen slechts enkele waarnemingen waren. De hoeveelheid beschikbare $\mathrm{N}$ komt redelijk overeen met normen en neemt toe van lage norm via overig naar hoge norm. Het $\mathrm{N}$-gehalte volgt redelijk de $\mathrm{N}$-gift, en neemt toe bij hogere beschikbare N. Hierop zijn echter uitzonderingen, en er is variatie tussen de rassen in Figuur 3.3. De gegevens op zandgrond zijn voornamelijk afkomstig van proefboerderij Vredepeel, met uitzondering van die van Hansa, en een viertal waarnemingen van Fontane. De cijfers geven daardoor redelijk verschillen tussen rassen weer, hoewel er ook nog effecten van teeltjaar mee kunnen spelen die hier niet verder geanalyseerd zijn. De gegevens op kleigrond zijn afkomstig van verschillende locaties en teeltjaren, waardoor er minder betrouwbare uitspraken gedaan kunnen worden over verschillen tussen rassen, mede gezien het lage aantal waarnemingen per ras. Voor een uitgebreidere analyse zijn meer data nodig, waarbij factoren als teeltjaar en teeltlocatie meegenomen dienen te worden.

Het P-gehalte vertoont meer variatie tussen rassen dan het $\mathrm{N}$-gehalte, waarbij het lage aantal waarnemingen ook een rol kan spelen. Desondanks zijn er op kleigrond ook verschillen tussen rassen waarvoor er meer dan 15 waarnemingen zijn. Ondanks selectie op P-klasse midden kan locatie hier een rol in spelen: cijfers voor Turbo en Maritiema zijn afkomstig uit Lelystad, Felsina uit Westmaas, en Agria uit Dronten en Westmaas. Mogelijke verschillen tussen rassen in P-gehalte hebben effect op de gewasafvoer. Gezien de variatie en betrouwbaarheid van de data wordt hierop in het voorliggende rapport niet verder ingegaan.

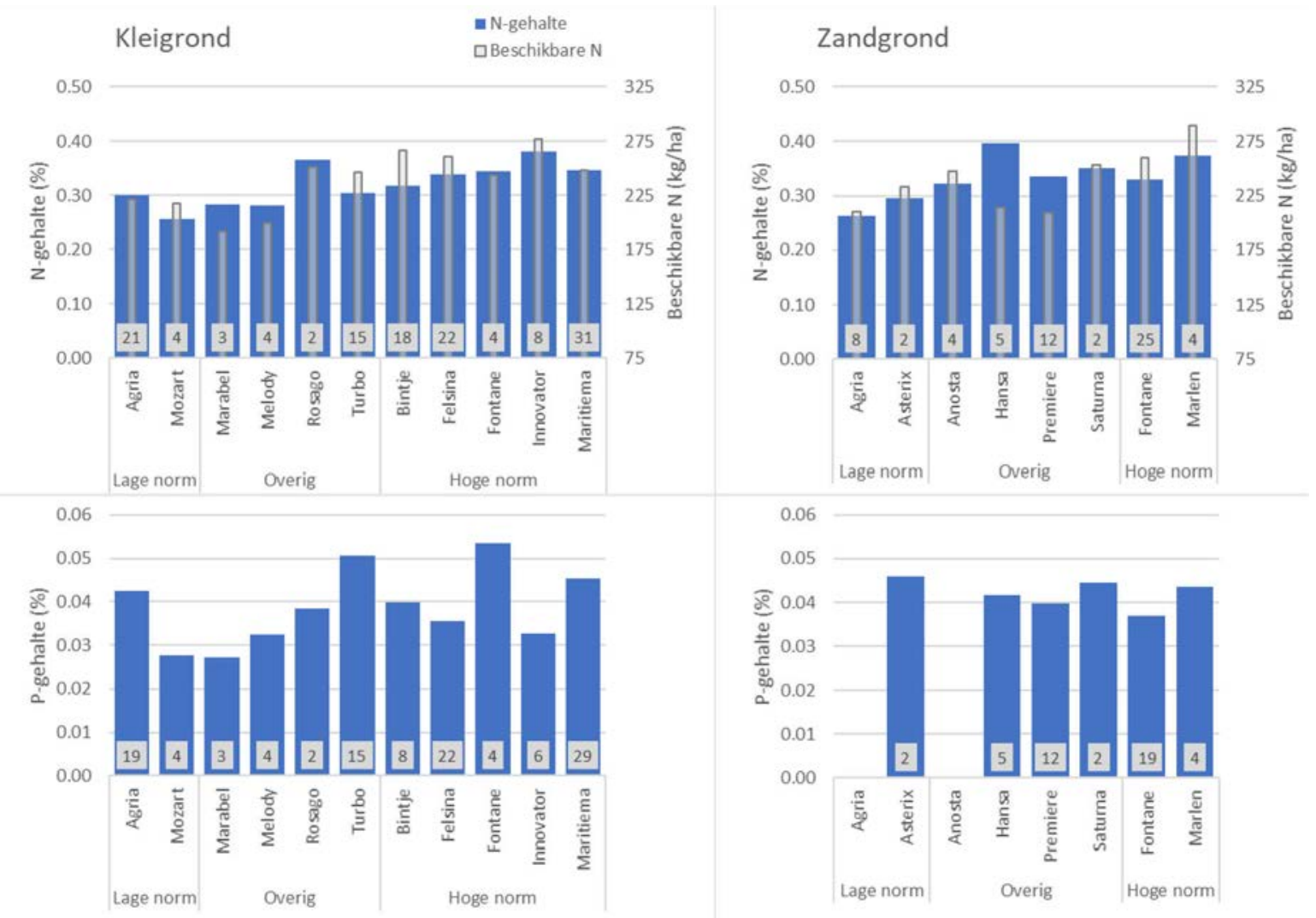

Figuur 3.3 N-gehalte (boven) en P-gehalte (onder) in consumptieaardappelrassen op kleigrond (links) en zandgrond (rechts), gerangschikt naar gebruiksnormklassen voor werkzame N (RVO, 2019) onder de selectie van $N$-range smal en P-klasse midden. Voor $N$ is tevens de beschikbare hoeveelheid $N$ weergegeven. Cijfers in de kolommen geven het aantal waarnemingen weer. 


\subsection{Vergelijking huidige gehalten met eerdere cijfers}

De gehalten gevonden in de voorliggende studie zijn vergeleken met eerdere cijfers van Beukeboom (1996) voor N en P, en met Ehlert et al. (2009) voor P (Tabel 3.10, Figuur 3.4 en Figuur 3.5). Relatieve verschillen worden gegeven in Figuur 3.6. Globaal gezien zijn de gehalten zoals gevonden in de voorliggende studie lager dan die uit Beukeboom (1996), met enkele uitzonderingen. Relatief is de daling iets groter bij N dan bij P (Figuur 3.6). Gehalten uit de voorliggende studie komen redelijk overeen met die uit Ehlert et al. (2009), ook weer met enkele uitzonderingen.

Van de hoofdproducten is de sterkste relatieve verandering bij suikerbieten voor zowel $\mathrm{N}$ als $\mathrm{P}$, waarbij de gehalten zoals gevonden in de voorliggende studie lager zijn dan die uit Beukeboom (1996). Bij zetmeelaardappelen en snijmais wordt voor zowel $\mathrm{N}$ als $\mathrm{P}$ een hoger gehalte gevonden dan Beukeboom (1996). Voor deze twee gewassen zijn de P-gehalten uit de voorliggende studie ook hoger dan die gerapporteerd door Ehlert et al. (2009). Dit laatste geldt ook voor pootaardappel.

Tabel $3.10 \mathrm{~N}$ - en P-gehalten (\%) in geoogst product uit de voorliggende studie, Beukeboom (1996) en Ehlert et al. (2009). Cijfers uit de voorliggende studie zijn gespecifieerd naar grondsoort indien van toepassing, en zijn mediane waarden. Wanneer zowel klei als zand gegeven zijn, is het k\&z cijfer het gemiddelde van deze twee. Zie hoofdstuk 3.3 voor bijbehorende mediane opbrengst en effecten van opbrengstniveau op het $N$ - en P-gehalte.

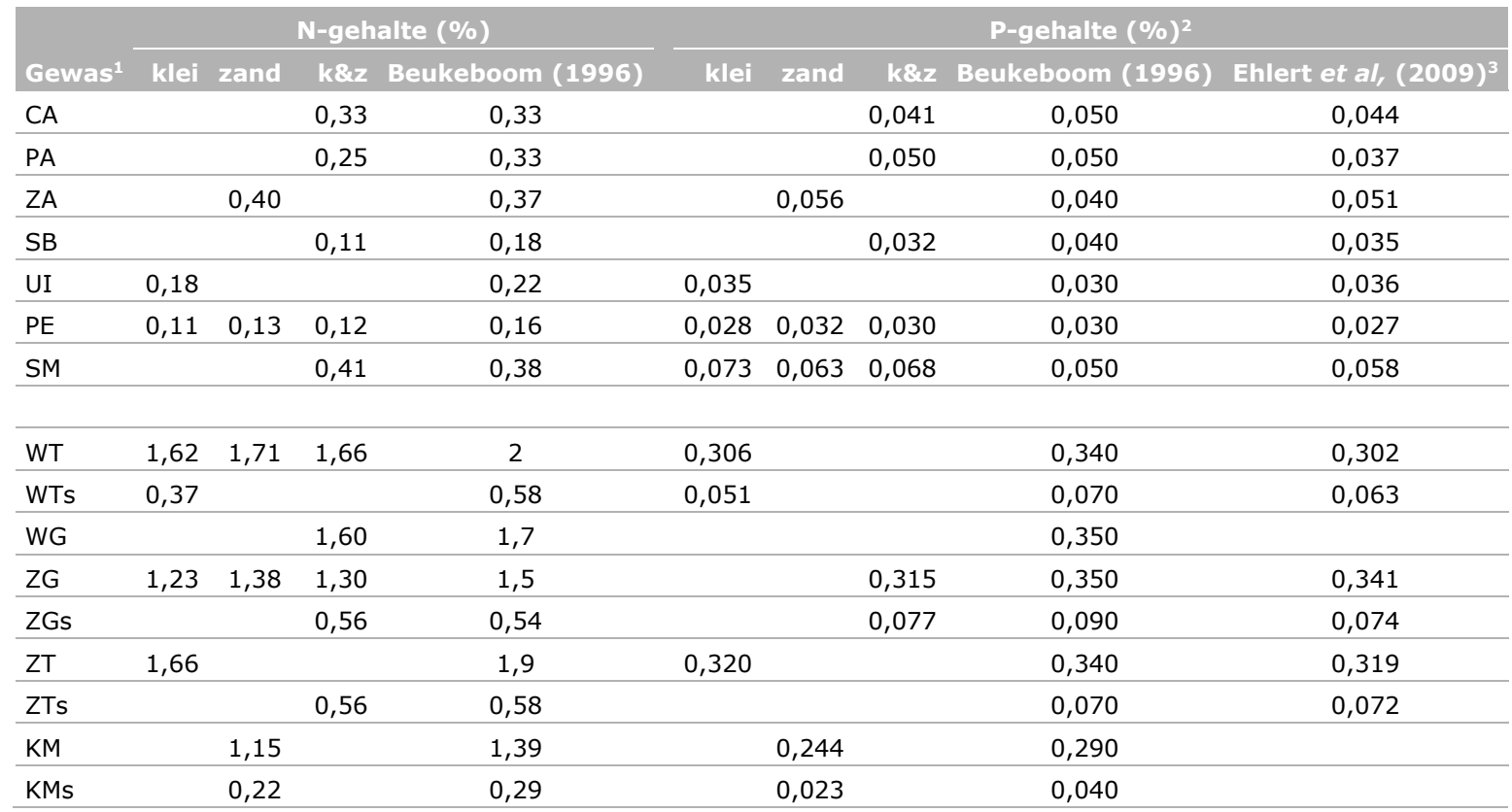

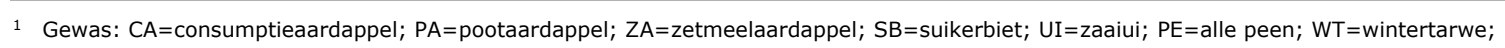
$\mathrm{ZT}=$ zomertarwe; $\mathrm{ZG=zomergerst;} \mathrm{SN}=$ snijmais; $\mathrm{KM}=$ korrelmais. De toevoeging ' $\mathrm{s}$ ' bij de granen betekent 'stro'.

2 Voor omrekening naar $\mathrm{P}_{2} \mathrm{O}_{5}$ vermenigvuldigen met 2,29.

3 Mediane waarden. 


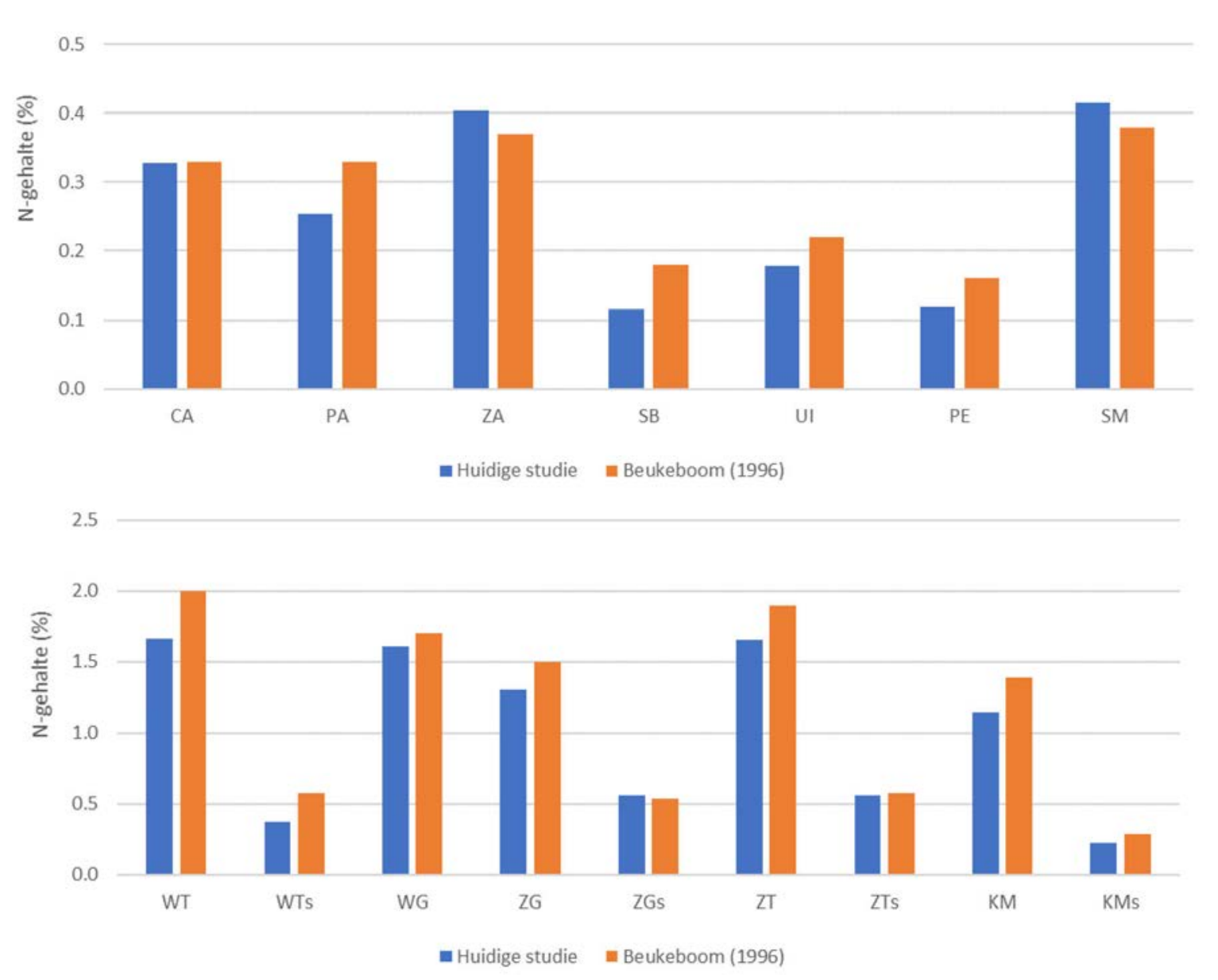

Figuur 3.4 N-gehalten (\%) in geoogst product van de voorliggende studie en uit Beukeboom (1996). Zie Tabel 3.10 voor onderliggende grondsoorten bij de cijfers van de huidige studie. Codering gewassen: $C A=$ consumptieaardappel; $P A=$ pootaardappel; $Z A=$ zetmeelaardappel; $S B=$ suikerbiet; $U I=$ zaaiui; $P E=$ alle peen; $W T=$ wintertarwe; $Z T=$ zomertarwe; $Z G=$ zomergerst; $S M=$ snijmais; $K M=k o r r e l m a i s$. De toevoeging ' $s$ ' bij de granen betekent 'stro'. 

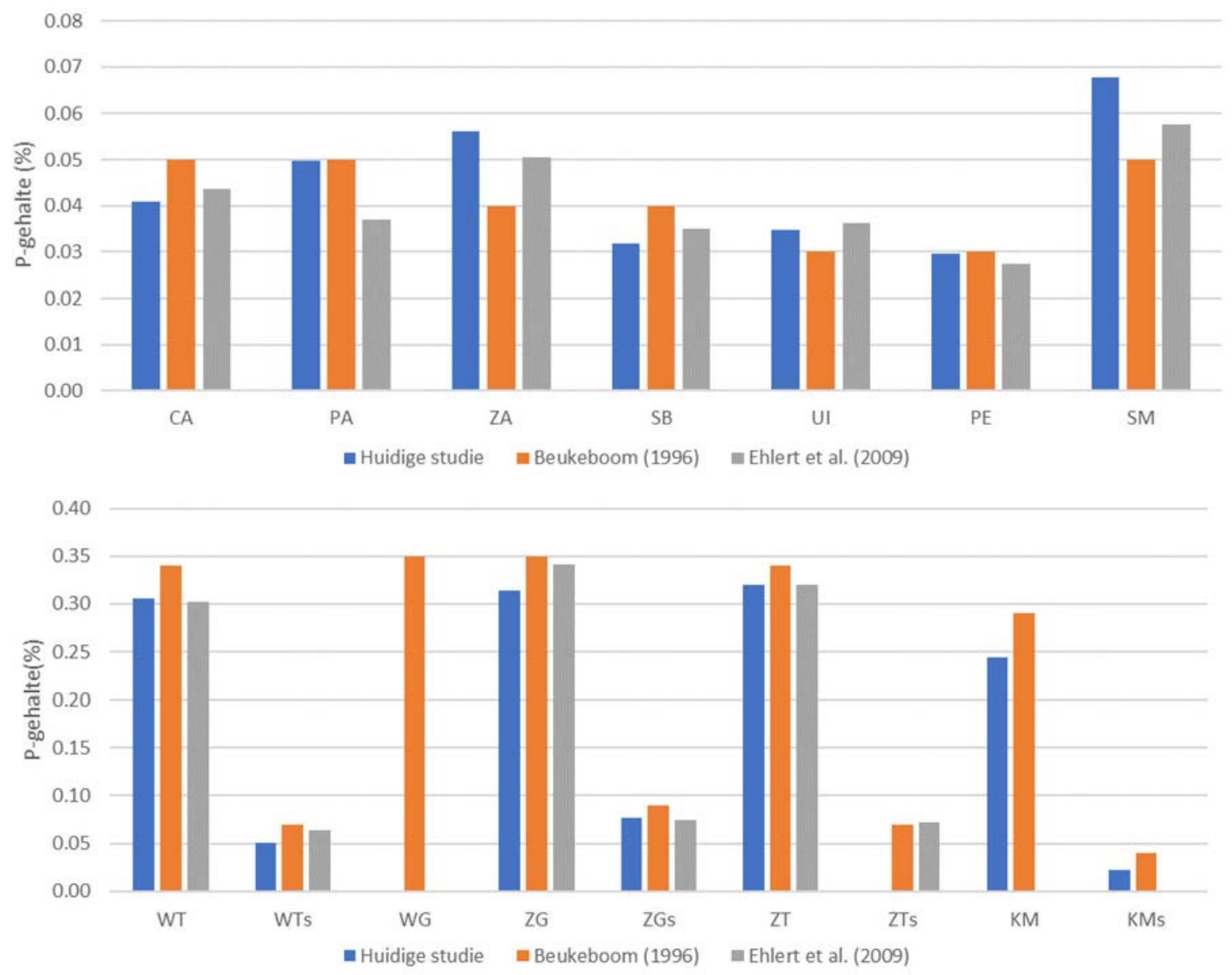

Figuur 3.5 P-gehalten (\%) in geoogst product van de voorliggende studie, uit Beukeboom (1996), en mediane waarden uit Ehlert et al. (2009). Zie Tabel 3.10 voor onderliggende grondsoorten bij de cijfers van de huidige studie. Codering gewassen: $C A=$ consumptieaardappel; $P A=$ pootaardappel; $Z A=$ zetmeelaardappel; $S B=$ suikerbiet; $U I=$ zaaiui; $P E=$ alle peen; $W T=$ wintertarwe; $Z T=z o m e r t a r w e ;$ $Z G=$ zomergerst; $S M=$ snijmais; $K M=$ korrelmais. De toevoeging 's' bij de granen betekent 'stro'. 
1.25

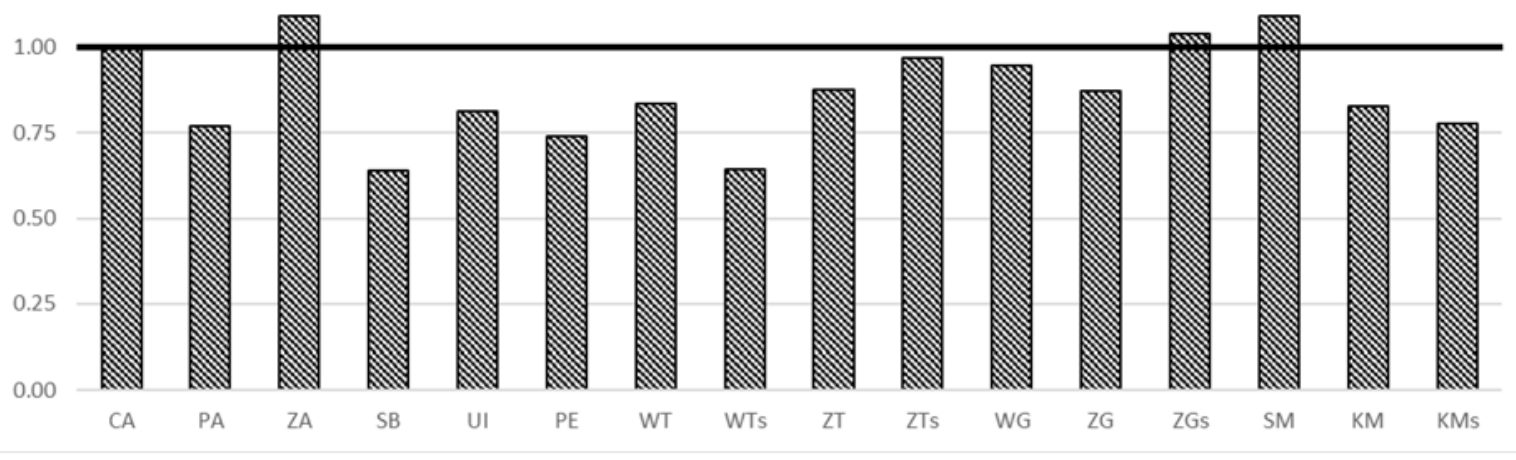

P-gehalte - verhouding huidig gehalte t.ov. Beukeboom (1996)

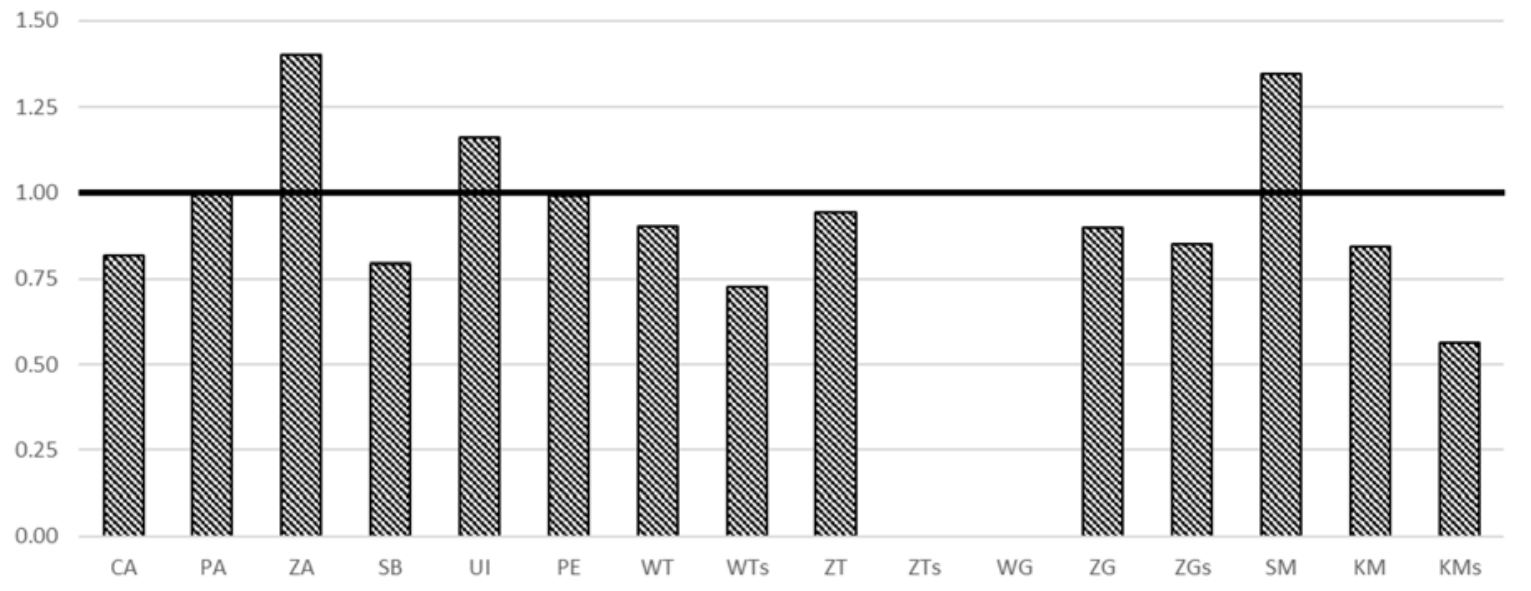

P-gehalte - verhouding huidig gehalte t.ov. Ehlert et al. (2009)

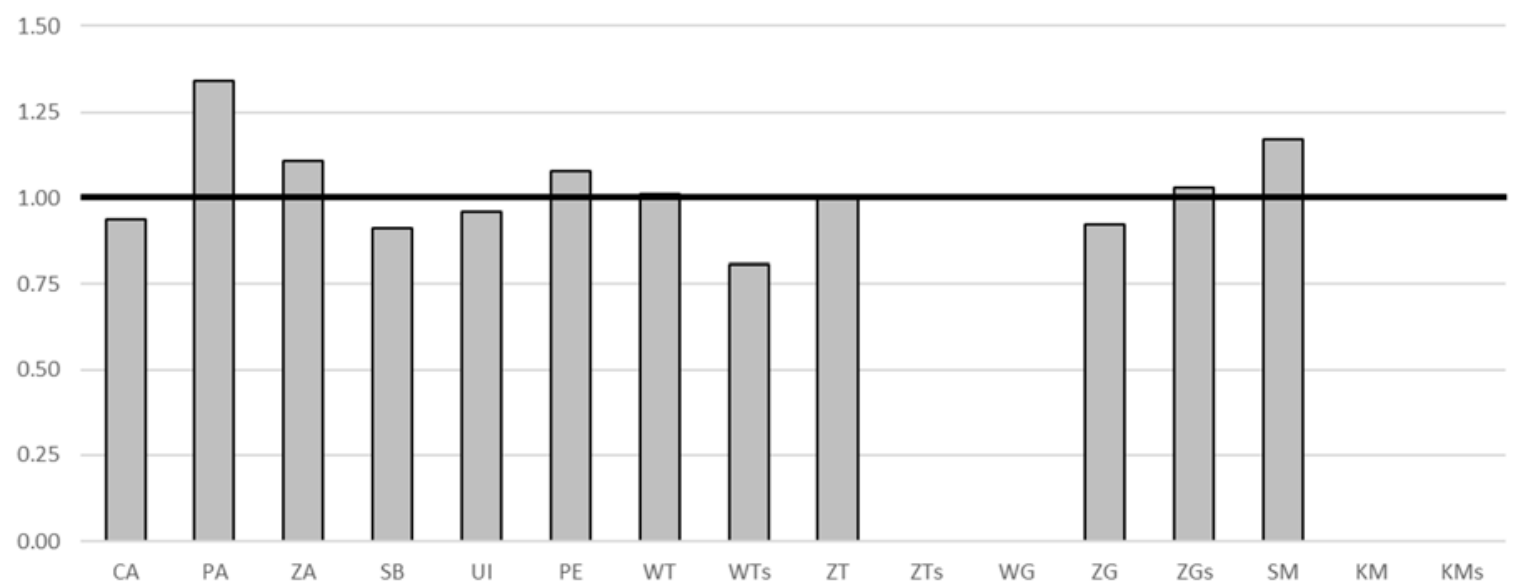

Figuur 3.6 Verhouding tussen gehalten uit de voorliggende studie en die uit Beukeboom (1996) voor N (boven) en P (midden), en die uit Ehlert et al. (2009) voor P (onder). 


\section{Discussie}

Voor het bepalen van gemiddelde of mediane waarden van $\mathrm{N}$ - en P-gehalten voor Nederland als geheel is een zo breed mogelijke dataset van belang. De huidige dataset is voor het merendeel opgebouwd met gegevens uit proeven met verschillende onderzoeksdoelen zoals bemestingsonderzoek (optimale gift, mestsoorten, timing van bemesting, toedieningswijze, deling van giften), grondbewerking, bedrijfssystemenonderzoek, gebruikswaardeonderzoek en gewasbeschermingsonderzoek. De proeven lagen op verschillende locaties en werden uitgevoerd in verschillende (reeksen van) jaren. Dit beperkt de mogelijkheden voor gedetailleerde statistische analyses op effecten van bijvoorbeeld grondsoort of ras omdat er ook effecten zijn van factoren als locatie, jaar van onderzoek, wijze van proefuitvoering, en bepalingsmethode voor $\mathrm{N}$ - en P-gehalte. Daarom zijn de $\mathrm{N}$ - en P-gehalten voor bouwlandgewassen met een groot areaal afgeleid via een combinatie van statistische analyse en selectie op basis van onderbouwde criteria, zoveel mogelijk gebruik makend van de breedte van de dataset. Voor de meeste gewassen betekent dit dat gebruik is gemaakt van gegevens van verschillende locaties, met wel een belangrijk aandeel afkomstig van de proeflocaties van WUR Open Teelten. Informatie over wintergerst en korrelmais komt slechts van één of twee locaties, waarbij het moeilijk in te schatten is hoe representatief de resultaten zijn voor andere delen van Nederland. Alle gegevens van wintergerst zijn afkomstig van proefboerderij Ebelsheerd in Nieuw Beerta met zware klei, en vrijwel alle gegevens van korrelmais zijn afkomstig van proeven op zandgrond bij Breda.

Binnen de dataset zijn selecties gemaakt op basis van uitgevoerde bemesting ten opzichte van het advies. Beschikbare $\mathrm{N}$ uit organische mest en de actuele adviesgift waren in de meeste gevallen bekend, en zijn ingeschat wanneer dat niet het geval is. Deze inschattingen zijn gebaseerd op aannames waardoor er enige onzekerheid zit rondom de ingeschatte waarden. Het effect van deze onzekerheid zal veelal beperkt zijn omdat er gewerkt wordt met $\mathrm{N}$-ranges en er dus enige variatie mogelijk is voordat de waarneming in een andere $\mathrm{N}$-range valt. Dit geldt bijvoorbeeld voor snijmais waar voor minder dan $10 \%$ van de waarnemingen bekend was of de kunstmest volvelds was toegediend of in de rij (met een hogere effectiviteit). Een eventuele foute inschatting daarvan zal waarschijnlijk weinig effect hebben op de uiteindelijke resultaten omdat een kleine verschuiving in de hoeveelheid beschikbare $\mathrm{N}$ nog steeds kan betekenen dat de waarneming in dezelfde $\mathrm{N}$-range valt. Mocht dat niet het geval zijn zal, dan zal het maar om een relatief beperkte verandering geven in de omvang van de selectie, waardoor het effect op het eindresultaat beperkt zal zijn. Hetzelfde geldt voor het inschatten van de $\mathrm{N}$-adviesgift voor snijmais op basis van veel of weinig mest in het verleden, en aannamen die gedaan zijn om ontbrekende informatie over historisch mestgebruik in te schatten. Het fosfaatadvies bij snijmais is in de loop van de tijd ingrijpend veranderd. Dit heeft echter weinig tot geen effect op de gevonden fosforgehalten, aangezien de gehalten gebaseerd op de P-klasse midden op zandgrond exact gelijk zijn aan die gebaseerd op de P-klasse verbreed waarbij de selectie van data alleen is gebaseerd op de P-toestand (zie Bijlage 7). Bij kleigrond zijn er minimale verschillen.

De selecties binnen de dataset op basis van uitgevoerde bemesting ten opzichte van het advies zijn gedaan om extremen zoals onbemeste objecten of zeer hoge giften niet mee te nemen en een betrouwbaar beeld van de $\mathrm{N}$ - en P-gehalten te krijgen, passend bij de bemestingsadviezen. Stikstofgebruiksnormen voor zuidelijk zand liggen voor sommige gewassen onder het adviesniveau, wat mogelijk een verlaging van het $\mathrm{N}$-gehalte geeft. De lagere bemesting ligt echter binnen de gehanteerde N-range van 0,75-1,25x het advies, waardoor de gevonden N-gehalten ook voor zuidelijk zand kunnen gelden. Voor $\mathrm{P}$ is geselecteerd op fosfaattoestand, waarbij de meest gehanteerde selectie P-midden uitgaat van de fosfaattoestanden voldoende en ruim voldoende (Pw tussen 20 en 45). Hogere P-toestanden en hoge P-bemesting kunnen leiden tot luxe consumptie van $\mathrm{P}$ en hogere P-gehalten (Ehlert et al., 2009, Ehlert et al., 2018). Het effect hiervan is in het voorliggende rapport niet gekwantificeerd, en de gegeven P-gehalten zijn passend bij het bemestingsadvies en fosfaattoestanden voldoende en ruim voldoende.

Biologische teelt is niet apart onderscheiden van gangbare teelt, veelal ook omdat er voor een aparte analyse slechts weinig data beschikbaar zijn. In de figuren waarin het gehalte tegen de versopbrengst 
is weergegeven (Bijlage 8), zijn de datapunten van biologische teelt wel afzonderlijke zichtbaar gemaakt. Teeltwijze kan wel een effect hebben op opbrengst en gehalte; bij de relatie tussen opbrengst en gehalte liggen de datapunten van biologische teelt in veel gevallen binnen het verband tussen gehalte en opbrengst van gangbare teelt.

Vergelijking van de uitkomsten van de P-gehalten uit het voorliggende rapport met die van Beukeboom (1996) en Ehlert et al. (2009) laat zien dat de gehalten meer overeenkomen met die van Ehlert et al. (2009), hetgeen ook te verwachten is aangezien dit een recentere studie is. Toch zijn er ook nog verschillen tussen de gehalten uit voorliggende studie en die uit Ehlert et al. (2009). Mogelijke verklaringen hiervoor zijn dat in de voorliggende studie alleen data vanaf 1990 zijn meegenomen; Ehlert et al. (2009) bevat ook data van eerdere jaren, en de voorliggende studie bevat data die na de studie van Ehlert et al. (2009) beschikbaar zijn gekomen. Wel is er overlap in de data die in beide studies zijn gebruikt, het bleek echter niet mogelijk om alle data vanaf 1990 die door Ehlert et al. (2009) gebruikt zijn mee te kunnen nemen in de voorliggende studie.

De uiteindelijke N- en P-gehalten zoals gepresenteerd in Tabel 3.4 en Tabel 3.5 zijn bepaald in proeven, en die zullen veelal bij oogst of kort na de oogst zijn bepaald. Dit betekent dat gewassen zoals aardappelen, uien en peen nog een relatief hoog vochtgehalte hebben. Bij bewaring van deze gewassen treedt door verdamping vochtverlies op wat leidt tot een verlaging van de hoeveelheid product en een verhoging van het $\mathrm{N}$ - en $\mathrm{P}$-gehalte in het versproduct. Berekening van de $\mathrm{N}$ - en P-afvoer van deze gewassen op basis van gehalten uit het voorliggende rapport en opbrengstcijfers na bewaring kan in het algemeen zo een onderschatting geven van de afvoer, waarbij de grootte afhankelijk is van het verschil in vochtgehalte.

Schröder et al. (2016) beschreven een toename van de opbrengst bij verschillende gewassen voor de perioden 2000-2015 en 2006-2014. In de voorliggende studie is geen gedetailleerde analyse van deze effecten over de tijd uitgevoerd, maar is in figuren het verloop van het $\mathrm{N}$ - en P-gehalte en de opbrengst in de periode 1990-2019 bekeken. De gewasopbrengst is bij de meeste gewassen toegenomen binnen de periode 1990-2019 (data niet getoond). Tegelijkertijd zijn in deze periode gehalten gedaald, veelal voor $\mathrm{N}$ relatief iets sterker dan voor $\mathrm{P}$. Een uitzondering hierop is zetmeelaardappel waar geen verandering van opbrengst werd gezien, maar wel een stijging van het $\mathrm{N}$ - en P-gehalte. In de voorliggende studie werden voor zetmeelaardappel ook hogere $\mathrm{N}$ - en P-gehalten gevonden dan die welke gepubliceerd door Beukeboom (1996) (Figuur 3.6).

Het effect van verhoging van de opbrengst en daling van gehalten wordt bij verschillende gewassen teruggevonden in de relaties tussen gehalte en opbrengst. Bij de gewassen suikerbiet, zaaiui en wintertarwe speelt dat voor zowel $\mathrm{N}$ en $\mathrm{P}$. Bij snijmais is er wel sprake van toename van opbrengst binnen de periode 1990-2019, maar is er bij het $\mathrm{N}$-gehalte geen verloop over de tijd. Het gevonden verband tussen $\mathrm{N}$-gehalte en opbrengst bij snijmaïs (Tabel 3.6) komt daardoor niet voort uit de combinatie van over de tijd toenemende opbrengst en afnemend gehalte. Waarschijnlijk komt het verband tussen $\mathrm{N}$-gehalte en opbrengst voort uit variatie binnen jaren, waarbij hoge opbrengsten gepaard gaan met lage gehaltes.

Graszaad is in de analyses niet meegenomen omdat de beschikbare cijfers het gemiddelde gehalte van zaad plus hooi betroffen. In de praktijk wordt hooi niet altijd afgevoerd, zodat cijfers voor de afzonderlijke onderdelen wel gewenst zijn. Een mogelijke analyse op verandering van gehalten ten opzichte van Beukeboom (1996) zou nog uitgevoerd kunnen worden omdat er wel informatie beschikbaar is over de opbrengsten van zaad en hooi. Door de gehalten uit Beukeboom (1996) voor zaad en hooi te combineren met opbrengstcijfers kan van daaruit een gewasgehalte berekend worden en vergeleken met het huidig gehalte. De bruikbaarheid hiervan is echter beperkt, ook al omdat graszaad in de database alleen Engels raaigras betreft.

Voor suikerbieten kan het P-gehalte ook geschat worden via een balans over de verschillende stromen bij de fabrieken van Suikerunie (Bijlage 9). Berekeningen zijn gedaan voor de jaren 2014 t/m 2017, waarbij de P-afvoer via het gewas is berekend als de som van alle P in Betacal, bietenpulp, melasse en bietenpunten. Het P-gehalte in het gewas wordt berekend door de P-afvoer via het gewas te delen door de totale hoeveelheid aangevoerde bieten. Gemiddeld over de vier jaren is het P-gehalte 0,034\%, wat dicht tegen de waarde van 0,032\% uit Tabel 3.5 ligt. 


\section{$5 \quad$ Conclusies}

- Voor bouwlandgewassen met een groot areaal ${ }^{1}$ zijn N- en P-gehaltes bepaald voor de periode 1990 2019 op basis van een uitgebreide dataset met voornamelijk gegevens uit het onderzoek en deels uit de praktijk.

- $\mathrm{N}$ - en P-gehaltes zijn voornamelijk bepaald op basis van situaties met bemesting rondom het adviesniveau; bij te weinig data is een bredere range gebruikt.

- In vergelijking met Beukeboom - Kiezen uit Gehalten (1996) zijn de N-gehalten uit de voorliggende studie lager, met uitzondering van consumptieaardappelen waarbij het gehalte vergelijkbaar was, en zetmeelaardappelen en snijmais waarbij het gehalte hoger was.

- De P-gehalten uit de voorliggende studie zijn lager dan die uit Beukeboom (1996) voor consumptieaardappelen, suikerbieten en granen, vergelijkbaar voor pootaardappelen en peen, en hoger voor zetmeelaardappelen, ui en snijmais. De P-gehalten uit de voorliggende studie komen redelijk overeen met die uit Ehlert et al. (2009), met als voornaamste uitzonderingen een hoger gehalte bij pootaardappel en snijmais.

- Voor een aantal gewassen zijn de $\mathrm{N}$ - en P-gehalten gespecificeerd naar de grondsoorten zand en klei.

- $\mathrm{N}$ - en P-gehalten nemen af met toenemend opbrengstniveau bij de gewassen suikerbiet, zaaiui en wintertarwe. Dit is ook het geval voor de $\mathrm{N}$-gehalten bij snijmais en korrelmais, en het P-gehalte bij zomergerst. Bij de gewassen pootaardappel en korrelmais werd voor het P-gehalte juist een hoger gehalte gevonden met toenemend opbrengstniveau.

1 Bouwlandgewassen met een groot areaal: consumptieaardappelen, pootaardappelen, zetmeelaardappelen, suikerbieten, zaai-uien, wintertarwe, zomertarwe, wintergerst, zomergerst, peen, snijmais en korrelmais. 


\section{Literatuur}

Avebe, 2018. Optimeelverslag teeltjaar 2017. https://www.avebe.nl/friksbeheer/wpcontent/uploads/2015/06/Optimeelverslag-teeltjaar-2017-.pdf.

Averis, 2019. Rasinformatie. https://www.averis. nl/rasinformatie/ (bezocht 20 augustus 2019).

Beukeboom, J.A., 1996. Forfaitaire gehalten voor de mineralenboekhouding. Informatie- en Kennis Centrum Landbouw, Ede, The Netherlands, 22 pp.

Bussink, D.W., Bakker, R.F., van der Draai, H., Temminghoff, E.J.M., 2011. Naar een advies voor fosfaatbemesting op nieuwe leest; deel 1 snijmaïs. Rapport 1246.1, Nutriënten Management Instituut NMI B.V., Wageningen.

CBAV, 2019. Commissie Bemesting Akkerbouw/Vollegrondsgroenteteelt, Handboek Bodem en Bemesting. https://www.handboekbodemenbemesting.nl

CBGV, 2019. Commissie Bemesting Grasland en Voedergewassen. Bemestingsadvies, versie 2019 (laatste wijziging: Augustus 2017). https://www.bemestingsadvies.nl/nl/bemestingsadvies.nl

Ehlert, P.A.I., J.C. van Middelkoop \& P.H.M. Dekker, 2006. Actualisatie van fosfaatgehalten en fosfaatafvoer van landbouwgewassen; een verkenning op basis van onderzoeksgegevens. Rapport 1348, Alterra, Wageningen, $92 \mathrm{pp}$.

Ehlert, P.A.I., P.H.M. Dekker, J.R. van der Schoot, R. Visschers, J.C. van Middelkoop, M.P. van der Maas, A.A. Pronk, A.M. van Dam, 2009. Fosforgehalten en fosfaatafvoercijfers van landbouwgewassen eindrapportage. Rapport 1773, Alterra, Wageningen.

Ehlert, P., J. van Middelkoop, W. van Geel, J. de Haan, I. Regelink, 2018. Veeljarige fosfaatveldproeven op gras- en bouwland. Syntheserapport. Wageningen Environmental Research, Rapport 2906.

Holshof G, Bussink D W, Van Middelkoop J C, Doppenberg G, Van Schooten H 2019 Naar een nieuw kalibemestingsadvies voor snijmaïs; Wageningen Livestock Research, rapport 1189.

LNV, 2017. Zesde Nederlandse actieprogramma betreffende de Nitraatrichtlijn (2018 - 2021). Ministerie van Landbouw, Natuur en Voedselkwaliteit; Ministerie van Infrastructuur en Waterstaat. https://www.rijksoverheid.nl/documenten/rapporten/2017/12/22/zesde-nederlandseactieprogramma-betreffende-de-nitraatrichtlijn-2018-2021.

NIVAA, 1994. Nederlandse catalogus van aardappelrassen. NIVAA, Den Haag, CPRO-DLO, Wageningen. NIVAP, 2007. Netherlands catalogue of potato varieties.

NIVAP, 2011. Netherlands catalogue of potato varieties/Nederlandse catalogus van aardappelrassen.

Oenema, O., J.P. Mol-Dijkstra, J.C. Voogd, P.A.I. Ehlert en G.L. Velthof, 2006. Klassenindelingen voor de fosfaattoestand van de bodem, ten behoeve van de afleiding van fosfaatgebruiksnormen. Rapport 2743, Alterra, Wageningen.

RVP-CSAR, 2019. Raad voor plantenrassen (Rvp) en Commissie Samenstelling Aanbevelende Rassenlijst (CSAR), Protocol cultuur- en gebruikswaarde-onderzoek van snij- en korrelmaïsrassen. https://www.raadvoorplantenrassen.nl/media/images/Protmais2019def.pdf.

RVO, 2019. Mestbeleid 2019-2021: tabellen. Tabel 2c Consumptieaardappelen hoge of lage norm.

Schröder, J.J., Aarts, H.F.M., De Bode, M.J.C., Van Dijk, W., Van Middelkoop, J.C., De Haan, M.H.A., Schils, R.L.M., Velthof, G.L., Willems, W.J., 2004. Gebruiksnormen bij verschillende landbouwkundige en milieukundige uitgangspunten. PRI rapport 79, Wageningen UR.

Schröder, J.J., G.L. Velthof, C. van Bruggen, C. Daatselaar, T. de Koeier, H. Prins \& K.J. Wolswinkel, 2016. Ontwikkeling van gewasopbrengsten in relatie tot gewijzigde gebruiksnormen; ex post vraag 8, Evaluatie Meststoffenwet 2016. Notitie, WPR, Wageningen UR, 29 pp.

Schröder, J.J. en W. van Dijk 2017 Actualisatie van stikstof-, fosfaat- en organische stof balansen van akkerbouw- en vollegrondsgroentenbedrijven. Onderzoek naar de aanpassing van gebruiksnormen in het kader van equivalente maatregelen. Rapport WPR-683.

Ten Berge, H.F.M., W. van Dijk, S. Burgers \& J.R. van der Schoot, 2012. Rekenregels voor differentiatie van de stikstofgebruiksnormen. PRI rapport 462, Wageningen UR, 71 pp. (geciteerd in Schröder en Van Dijk, 2017).

Van der Schoot, J.R. en W. van Dijk 2001. Afvoer van stikstof en fosfaat geen vast gegeven - PPO Bulletin Akkerbouw $\mathrm{nr}$ 3: 11-15.

Van Dijk, W., 2003. Adviesbasis voor de bemesting van akkerbouw- en vollegrondsgroentengewassen. PPO-publicatie nr. 307, Praktijkonderzoek Plant \& Omgeving, Lelystad, 66 pp. 


\section{Bijlage 1 Overzicht databronnen}

\section{Consumptieaardappel}

- Bussink W, G Doppenberg, W Van den Berg, K Van Wijk (2014). Naar een nieuw fosfaatbemestingsadvies in de akkerbouw. Masterplan Mineralenmanagement, Productschap Akkerbouw, Zoetermeer, $43 \mathrm{pp}$.

- De Ruijter F J, Ten Berge H F M, Van Dijk W, Kroonen-Backbier B M A, Slabbekoorn J J, Dekker P H M (2009). Verkenning gedifferentieerde N-gebruiksnorm in consumptieaardappel. Experimenten in Telen met toekomst 2008. Wageningen UR, Plant Research International, Rapport 303.

- Dekker, P., J. Paauw, W. van den Berg, J. Huijsmans en B. Vermeulen (2009). Mesttoepassing in consumptieaardappelen 2008. Voorjaarstoepassing op kleigrond. PPO nr. 3250103608, PPO-AGV, Lelystad

- Dekker, P.H.M., J.G.M. Paauw, W. van den Berg, J. Huijsmans, B. Vermeulen \& P. van Velde (2007). Mesttoediening in het voorjaar op klei bouwland; consumptieaardappel. PPO nr. 3250028500, PPOAGV, Lelystad.

- Dekker, P.H.M., J.G.M. Paauw \& W. van den Berg (2007). Biogas Flevoland. Verslag van het veldonderzoek in 2006 naar de landbouwkundige waarde van covergiste mest. PPO nr. 3251046400, PPO-AGV, Lelystad.

- Dekker, P.H.M., J.G.M. Paauw \& W. van den Berg (2008). Biogas Flevoland. Verslag van het veldonderzoek in 2007 naar de landbouwkundige waarde van covergiste mest. PPO nr. 3251046400, PPO-AGV, Lelystad.

- Dekker, P.H.M., W. van den Berg \& J.J. Slabbekoorn (2006). Alternatieven voor ontijdige toediening van dierlijke mest in de akkerbouw. Effect mestsoort, mestscheidingsproducten, tijdstip van aanwenden van mest en gebruik van een groenbemester op de N-benutting bij aardappelen op klei. Verslag van drie jaar veldonderzoek op PPO-proefbedrijf in Westmaas, Seizoenen 2002/2003, 2003/2004 en 2004/2005. PPO projectnr. 510170, PPO-AGV, Lelystad.

- interne data WUR Open Teelten, project BASIS

- interne data WUR Open Teelten

- Malda, J.T., R. Rutgers \& E.S.C. Stilma (2011). Bemestingsonderzoek aardappelen. Het effect van de hoogte van de $\mathrm{N}$-gift en het type $\mathrm{N}$-meststof op opbrengst en kwaliteit van consumptieaardappelen (Agria) op een Flevolandse kleigrond in 2011. Project: 11-1815PA. Altic, Dronten.

- Paauw, J.G.M., D. van Balen, J.J. de Haan, M.J.G. de Haas, H. van der Draai \& D.W. Bussink (2012). Effecten bodem- en structuurverbeteraars. Onderzoek op klei-, zand- en dalgrond 2011. PPO nr. 481, Praktijkonderzoek Plant \& Omgeving, onderdeel van Wageningen UR, Business Unit Akkerbouw, Groene Ruimte en Vollegrondsgroenten, Lelystad.

- Postma R, Dekker P, Van Schöll L, Paauw J, Wijnholds K, Verstegen H (2009). Toetsing van meststoffen en bemestingssystemen in de aardappelteelt; veldproeven 2006-2008. NMI-rapport 1161, NMI, Wageningen, 49 pp.

- Russchen H J, Mager A (2005). De efficiëntie van N-bladbemesting in consumptieaardappelen van het ras Felsina KW 0522 SPNA Altic.

- Russchen H J, Mager A (2005). De invloed van N-bemesting in verschillende jaren op de opbrengst van consumptieaardappelen KW 0623 SPNA Altic.

- Rutgers, R. \& J.T. Malda (2012). N-bemesting aardappel. Meerjarige onderzoeksresultaten van de stikstofbenutting van vloeibare $\mathrm{N}$-meststoffen in de teelt van aardappelen op locaties in Noordoosten Zuidoost-Nederland en in de Flevopolder in de jaren 2010 t/m 2012. Rapport 12-2819 PA, Altic, Dronten.

- Schröder J.J., J.W. Steenhuizen, A.G. Jansen, B. Fraters \& A. Siepel (2003). Opbrengst, mineralenverlies en bodemvruchtbaarheid van een biologisch akkerbouwbedrijf in relatie tot bemestingsniveaus. Resultaten van het Ecologisch Proefbedrijf Dr H.J. Lovinkhoeve 1996 - 2002. Plant Research International B.V., Wageningen, Rapport 69.

- Slabbekoorn, H. \& P. Dekker (2008b). Effect van toepassing effectieve micro-organismen in consumptieaardappelen 2008. PPO projectnr. 32.500.619.00, PPO-AGV, Westmaas. 
- Slabbekoorn, H. (2011). Rijenbemesting in aardappelen. Verslag van een veldproef op zuidwestelijke zeeklei in 2011. PPO nr. 32502168 00, PPO-AGV, Westmaas.

- Smit, B., W. van Geel, J.T. Malda, A. Pronk (2013). Rijenbemesting: kansen, nieuwe producten en technieken. Rapportage 2012 en 2013. Stichting DLO / PRI, Wageningen.

- Ten Berge H F M en Kroonen-Backbier B M A (2008). Effecten van gereduceerd bemesten in consumptieaardappel op drie praktijkpercelen. BO-05-infoblad 16.

- Van Balen, D.J.M., C.G. Topper, W.C.A. van Geel, J.J. de Haan, W. van den Berg, M.J.G. de Haas \& D.W. Bussink (2016). Effecten bodem- en structuurverbeteraars. Onderzoek op klei- en zandgrond 2010-2015; Eindrapportage. PPO publicatienummer: 693. Projectnummer: 3250159600. Praktijkonderzoek Plant \& Omgeving, onderdeel van Wageningen UR, Business Unit Akkerbouw, Groene Ruimte en Vollegrondsgroenten, Lelystad.

- Van der Schans, D.A., F. van Evert, J.T. Malda \& V. Dorka-Vona (2012). Sensorgestuurde advisering van stikstofbijbemesting in aardappel, Implementatie en integratie. PPO nr. 520. PPO-AGV, Lelystad.

- Van der Schoot J R, Neuvel J, Van Dijk W (2002). Interactie stikstof- en fosfaatvoorziening bij aardappel. Wageningen UR, Praktijkonderzoek Plant en Omgeving, Projectrapport nr. 11 25.2.36.

- Van Evert, F.K., D.A. van der Schans, J.T. Malda, W. van den Berg, W.C.A. va Geel \& J.N. Jukema (2011). Geleide N-bemesting voor aardappelen op basis van gewasreflectiemetingen. Integratie van sensormetingen in een N-bijmestsysteem. PPO nr. 423. PPO-AGV, Lelystad.

- Van Geel, W., B. Kroonen-Backbier, D. van der Schans \& J.T. Malda (2014). Nieuwe bijmestsystemen en -strategieën voor aardappel op zand- en lössgrond. Deel 2: resultaten veldproeven 2012 en 2013. PPO nr. 615., PPO-AGV, Lelystad.

- Van Geel W, Van den Berg W, Van Dijk W, Wustman R (2012). Aanvullend onderzoek mineralenconcentraten 2009-2011 op bouwland en grasland. Samenvatting van de resultaten uit de veldproeven en bepaling van de stikstofwerking. PPO 476, PPO-AGV, Lelystad.

- Van Geel, W., W. van Dijk \& W. van den Berg (2012). Stikstofwerking van mineralenconcentraten bij aardappelen. Verslag van veldonderzoek in 2009 en 2010. PPO nr. 475, PPO-AGV, Lelystad.

\section{Pootaardappel}

- Alblas, J \& H. Floot (2002). Druppelirrigatie met brak water voor schurftbestrijding in pootaardappelen. Projectrapport nr. 1123410-1, PPO Lelystad.

- Bussink W, G Doppenberg, W Van den Berg, K Van Wijk (2014). Naar een nieuw fosfaatbemestingsadvies in de akkerbouw. Masterplan Mineralenmanagement, Productschap Akkerbouw, Zoetermeer, 43 pp.

- Dekker, P.H.M., J.G.M. Paauw \& W. van den Berg (2007). Biogas Flevoland. Verslag van het veldonderzoek in 2006 naar de landbouwkundige waarde van covergiste mest. PPO nr. 3251046400, PPO-AGV, Lelystad.

- Dekker, P.H.M., J.G.M. Paauw \& W. van den Berg (2008). Biogas Flevoland. Verslag van het veldonderzoek in 2007 naar de landbouwkundige waarde van covergiste mest. PPO nr. 3251046400, PPO-AGV, Lelystad.

- interne data WUR Open Teelten, project BASIS.

- Paauw, J.G.M., D. van Balen, J.J. de Haan, M.J.G. de Haas, H. van der Draai \& D.W. Bussink (2012). Effecten bodem- en structuurverbeteraars. Onderzoek op klei-, zand- en dalgrond 2011. PPO nr. 481, Praktijkonderzoek Plant \& Omgeving, onderdeel van Wageningen UR, Business Unit Akkerbouw, Groene Ruimte en Vollegrondsgroenten, Lelystad.

- Van Balen, D.J.M., C.G. Topper, W.C.A. van Geel, J.J. de Haan, W. van den Berg, M.J.G. de Haas \& D.W. Bussink (2016). Effecten bodem- en structuurverbeteraars. Onderzoek op klei- en zandgrond 2010-2015; Eindrapportage. PPO publicatienummer: 693. Projectnummer: 3250159600. Praktijkonderzoek Plant \& Omgeving, onderdeel van Wageningen UR, Business Unit Akkerbouw, Groene Ruimte en Vollegrondsgroenten, Lelystad.

- Vermeulen, G.D., C. van der Wel, J.G.M. Paauw, W.J. Bakker \& P. Kramer (2009). Ruggenteelt als bedrijfssysteem in het noordelijke kleigebied. Verslag van onderzoek in de periode 2006-2008. PRI, Wageningen.

\section{Zetmeelaardappel}

- Bussink W, G Doppenberg, W Van den Berg, K Van Wijk (2014). Naar een nieuw fosfaatbemestingsadvies in de akkerbouw. Masterplan Mineralenmanagement, Productschap Akkerbouw, Zoetermeer, 43 pp. 
- interne data WUR OT.

- Postma R, Dekker P, Van Schöll L, Paauw J, Wijnholds K, Verstegen H (2009). Toetsing van meststoffen en bemestingssystemen in de aardappelteelt; veldproeven 2006-2008. NMI-rapport 1161, NMI, Wageningen, 49 pp.

- Rutgers, R. \& J.T. Malda (2012). N-bemesting aardappel. Meerjarige onderzoeksresultaten van de stikstofbenutting van vloeibare $\mathrm{N}$-meststoffen in de teelt van aardappelen op locaties in Noordoosten Zuidoost-Nederland en in de Flevopolder in de jaren 2010 t/m 2012. Rapport 12-2819 PA, Altic, Dronten.

- Uenk D, Grashoff C, Van Geel W C A (2003). Stikstofbijbemesting op aardappelen op basis van omgekeerde $\mathrm{N}$-vensters in combinatie met CropScan-Jaarrapport 2002. Wageningen UR, Plant Research International, Nota 266.

- Uenk D, Grashoff C, Van Geel W C A (2005). Stikstofbijbemesting op aardappelen op basis van omgekeerde $\mathrm{N}$-vensters in combinatie met CropScan. Afrondend rapport over de proefjaren 2002 en 2003. Wageningen UR, Plant Research International, Nota 336.

- Van Geel, W. \& D. van der Schans (2015). Toepassing van NBS-aardappelsensing in de teelt van zetmeelaardappelen. IJkakker; Veldproef 2014 't Kompas. PPO/PRI-rapport 655, Wageningen UR.

- Van Geel W, Van den Berg W, Van Dijk W, Wustman R (2012). Aanvullend onderzoek mineralenconcentraten 2009-2011 op bouwland en grasland. Samenvatting van de resultaten uit de veldproeven en bepaling van de stikstofwerking. PPO 476, PPO-AGV, Lelystad.

- Van Geel, W., W. van Dijk \& W. van den Berg (2012). Stikstofwerking van mineralenconcentraten bij aardappelen. Verslag van veldonderzoek in 2009 en 2010. PPO nr. 475, PPO-AGV, Lelystad.

- Van Geel, W.C.A., K.H. Wijnholds \& C. Grashoff (2004). Ontwikkeling van geleide bemestingssystemen bij de teelt van zetmeelaardappelen 2002-2003. PPO nr. 510168, PPO-AGV, Lelystad.

- Wijnholds, K.H. (2005a). Invloed van stikstof en ras op opbrengst en eiwitgehalte van zetmeelaardappelen. PPO nr. 510127, PPO-AGV, Valthermond.

- Wijnholds, K.H. (2005b). Invloed van stikstofniveau en -deling op eiwitgehalte en opbrengst van zetmeelaardappelen. PPO nr. 510428, PPO-AGV, Valthermond.

\section{Graszaad (Engels raaigras)}

- Borm G E L en Van der Schoot J R (2001). Optimalisatie stikstofbemesting Engels raaigras, oogst 2000. Projectrapport 1146218.

- Borm G E L en Van der Schoot J R (2003). Optimalisatie stikstofbemesting Engels raaigras, oogst 2001. Projectrapport.

- Borm G E L en Van der Schoot J R (2004). Optimalisatie stikstofbemesting Engels raaigras, oogst 2002. Projectrapport 5146218.

- Van der Schoot J R en Borm G E L (2004). Optimalisatie stikstofbemesting Engels raaigras, oogst 2003. Projectrapport 5146218.

- Van der Schoot J R en Borm G E L (2005) Optimalisatie stikstofbemesting Engels raaigras, oogst 2004 en verwerking over jaren. Projectrapport 5146218.

- Van der Schoot J R en Borm G E L (2005). Zwavelbemesting graszaad Engels raaigras. Effect van zwavelbemesting op opbrengst en kwaliteit van Engels raaigras bestemd voor zaadproductie, oogst 2004. Projectrapport 510251.

- Van der Schoot J R en Borm G E L (2005). Zwavelbemesting graszaad Engels raaigras. Effect van zwavelbemesting op opbrengst en kwaliteit van Engels raaigras bestemd voor zaadproductie, oogst 2004. Projectrapport 510251.

- Van der Schoot J R en Borm G E L (2006). Zwavelbemesting graszaad Engels raaigras. Effect van zwavelbemesting op opbrengst en kwaliteit van Engels raaigras bestemd voor zaadproductie, oogst 2005. Projectrapport 510251.

- Van der Schoot J R en Borm G E L (2006). Zwavelbemesting graszaad Engels raaigras. Effect van zwavelbemesting op opbrengst en kwaliteit van Engels raaigras bestemd voor zaadproductie, oogst 2005. Projectrapport 510251.

- Van der Schoot J R en Borm G E L (2006). Optimalisatie stikstofbemesting Engels raaigras, oogst 2005. Projectrapport 5146218.

- Van der Schoot J R en Borm G E L (2007) Zwavelbemesting graszaad Engels raaigras, oogst 2006 en meerjarenanalyse. Projectrapport 510251. 
- Van der Schoot J R en Borm G E L (2007). Zwavelbemesting graszaad Engels raaigras, oogst 2006 en meerjarenanalyse. Projectrapport 510251.

\section{Peen}

- Bussink W, G Doppenberg, W Van den Berg, K Van Wijk (2014). Naar een nieuw fosfaatbemestingsadvies in de akkerbouw. Masterplan Mineralenmanagement, Productschap Akkerbouw, Zoetermeer, $43 \mathrm{pp}$.

- Interne data WUR Open Teelten.

- Interne data WUR Open Teelten, project BASIS.

- Schröder J J, Steenhuizen J W, Jansen A G, Fraters B, Siepel A (2003). Opbrengst, mineralenverlies en bodemvruchtbaarheid van een biologisch akkerbouwbedrijf in relatie tot bemestingsniveaus. Resultaten van het Ecologisch Proefbedrijf Dr H.J. Lovinkhoeve 1996 - 2002. Plant Research International B.V., Wageningen, Rapport 69.

- Topper C G, Van Balen D, Verstegen H, De Haan J J, De Haas M J G, Doppenberg G J, Bussink D W (2013). Effecten bodem- en structuurverbeteraars. Onderzoek op klei-, zand- en dalgrond. Resultaten 2013. PPO nr. 597, Praktijkonderzoek Plant \& Omgeving, onderdeel van Wageningen UR, Business Unit Akkerbouw, Groene Ruimte en Vollegrondsgroenten, Lelystad.

- Van Balen D J M, Topper C G, Van Geel W C A, De Haan J J, Van den Berg W, De Haas M J G, Bussink D W (2016). Effecten bodem- en structuurverbeteraars. Onderzoek op klei- en zandgrond 2010-2015; Eindrapportage. PPO-publicatienummer 693. Projectnummer: 3250159600. Praktijkonderzoek Plant \& Omgeving, onderdeel van Wageningen UR, Business Unit Akkerbouw, Groene Ruimte en Vollegrondsgroenten, Lelystad.

\section{Snijmais}

- Bruinenberg M, Van Schooten H, Van Dijk W (2003). Lange termijn effecten gereduceerde mestgiften op maisland 1996-2002. Animal Sciences Group intern rapport 511.

- Bussink D W, Bakker R F, Van der Draai H, Temminghoff E J M (2011). Naar een advies voor fosfaatbemesting op nieuwe leest; deel 1 maïsland. Nutriënten management instituut rapport 1246.1.

- Bussink W, G Doppenberg, W Van den Berg, K Van Wijk (2014). Naar een nieuw fosfaatbemestingsadvies in de akkerbouw. Masterplan Mineralenmanagement, Productschap Akkerbouw, Zoetermeer, 43 pp.

- CGO maïs; interne data.

- Dijk. W. van (1997). Ondiepe toediening van dierlijke mest bij maïs. PAV-bulletin akkerbouw, februari 1997.

- Geelen P M T M, Crombach C, Van der Schoot J R, Alblas J, Dekker P H M (2002). Verdieping en praktisering kennis over stikstof in het mergelland. Resultatenteeltjaar 2001.

- Geelen P M T M, Dekker P H M (2001). Verdieping en praktisering kennis over stikstof in het mergelland. Resultatenteeltjaar 2000.

- Geelen P M T M, Dekker P H M (2001). Verdieping en praktisering kennis over stikstof in het mergelland. Resultatenteeltjaar 1999.

- Geelen, P.M.T.M, Alblas, april 2002, Stikstofproblematiek van de akkerbouw en melkveehouderij in het mergelland. Resultaten akkerbouw 1995-1998, deel I en II. Projectrapport 1125221.

- Holshof G, Bussink D W, Van Middelkoop J C, Doppenberg G, Van Schooten H (2019). Naar een nieuw kalibemestingsadvies voor snijmaïs; Wageningen Livestock Research, rapport 1189.

- Interne data WUR Open Teelten.

- Schröder J en De la Lande Cremer L C N (1989). Toedienen van drijfmest in mais vervolgonderzoek 1985 - 1987. PAGV-verslag 85.

- Schröder J J, A.G. Jansen \& G.J. Hilhorst (2005). Long-term nitrogen supply from cattle slurry. Soil Use and Management 21,196-204

- Schröder J J, Steenhuizen J W, Jansen A G, Fraters B, Siepel A (2003). Opbrengst, mineralenverlies en bodemvruchtbaarheid van een biologisch akkerbouwbedrijf in relatie tot bemestingsniveaus. Resultaten van het Ecologisch Proefbedrijf Dr H.J. Lovinkhoeve 1996 - 2002. Plant Research International B.V., Wageningen, Rapport 69.

- Schröder J J, Ten Holte L (1996). Bemestingsonderzoek aan mais en voederbieten op De Marke (1990-1995). PR rapport 16, AB-DLO rapport 63.

- Schröder J (1990). Stikstofdeling bij snijmais. PAGV-verslag 106. 
- Schröder J (1992). Effecten van wintergewassen op de uitspoeling van stikstof bij de teelt van snijmaïs. PAGV-verslag 148.

- Van der Schans D (1995). Invloed van plantverdeling, zaaitijdstip en koudetolerantie op de stikstofbenutting door maïs tijdens de jeugdgroei. PAGV verslag no. 191.

- Van der Schans D, Meuffels G, Van der Schoot J R, Van Dijk W, Vermeulen B (2011). Precisieplaatsing van drijfmest in Mais. PPO Publicatie 436.

- Van der Schoot J R \& W van Dijk (2002). Interactie stikstof- en fosfaatvoorziening bij snijmais. Project rapport nr. 110017 (proef REG0610 en REG0611)

- Van der Schoot J R - interne rapportage.

- Van der Schoot J R (1999). Maisteelt bij suboptimale vochtvoorziening PPO510019.

- Van der Schoot J R (2000). Maisteelt bij suboptimale vochtvoorziening PPO510019.

- Van der Schoot J R (2001). Maisteelt bij suboptimale vochtvoorziening PPO510019.

- Van der Schoot J R, Van Dijk W (2002). Interactie stikstof- en fosfaatvoorziening bij snijmais. Project rapport nr. 110017 (proef REG0610 en REG0611).

- Van Dijk T A (2008). Vergelijking van diverse rijenbemestingssystemen bij snijmaïs. Nutriënten management instituut rapport 1250.N.07, 31 pp.

- Van Dijk T A (2009). Vergelijking van diverse rijenbemestingssystemen bij snijmaïs. Nutriënten management instituut rapport 1250.N.08, 24 pp.

- Van Dijk W (1996). Invloed van N-rijenbemesting op drogestofproductie en N-benutting bij snijmais. PAGV-verslag no. 215.

- Van Dijk W, Baan Hofman T, Nijssen K (1996). Effecten van maïs-gras vruchtwisseling. PAGVverslag no. 217.

- Van Dijk W, Schröder J J, Ten Holte L, De Groot W J (1995). Effecten van wintergewassen op verliezen en benutting van stikstof bij de teelt van snijmais. PAGV-verslag 201.

- Van Schooten H A, I C Hoving, P H M Dekker en J W van Riel (2008). Indicator voor mineralisatie op gescheurd grasland. ASG rapport 89.

- Van Schooten N, Van Riel J W (2011). Snijmais met beperkt kunstmestfosfaat. Tweejarig veldonderzoek met verschillende vormen van rijenbemesting WLR Rapport 499.

\section{Suikerbiet}

- Bussink W, G Doppenberg, W Van den Berg, K Van Wijk (2014). Naar een nieuw fosfaatbemestingsadvies in de akkerbouw. Masterplan Mineralenmanagement, Productschap Akkerbouw, Zoetermeer, 43 pp.

- Interne data WUR Open Teelten, project BASIS.

- Interne data WUR OT.

- Pauw, J.G.M., D. van Balen, J.J. de Haan, M.J.G. de Haas, H. van der Draai \& D.W. Bussink (2012). Effecten bodem- en structuurverbeteraars. Onderzoek op klei-, zand- en dalgrond 2011. PPO nr. 481, Praktijkonderzoek Plant \& Omgeving, onderdeel van Wageningen UR, Business Unit Akkerbouw, Groene Ruimte en Vollegrondsgroenten, Lelystad.

- Paauw, J.G.M., D. van Balen, J.J. de Haan, M.J.G. de Haas, H. van der Draai \& D.W. Bussink (2013). Effecten bodem- en structuurverbeteraars. Onderzoek op klei-, zand- en dalgrond 2012. Resultaten na drie jaar onderzoek. PPO nr. 481, Praktijkonderzoek Plant \& Omgeving, onderdeel van Wageningen UR, Business Unit Akkerbouw, Groene Ruimte en Vollegrondsgroenten, Lelystad.

- Schröder J.J., J.W. Steenhuizen, A.G. Jansen, B. Fraters \& A. Siepel (2003). Opbrengst, mineralenverlies en bodemvruchtbaarheid van een biologisch akkerbouwbedrijf in relatie tot bemestingsniveaus. Resultaten van het Ecologisch Proefbedrijf Dr H.J. Lovinkhoeve 1996 - 2002. Plant Research International B.V., Wageningen, Rapport 69.

- Stichting IRS, interne database (ca een derde van de suikerbietengegevens in de voorliggende studie zijn afkomstig van IRS, veelal gerapporteerd in openbare IRS-rapporten)

- Van Balen, D.J.M., C.G. Topper, W.C.A. van Geel, J.J. de Haan, W. van den Berg, M.J.G. de Haas \& D.W. Bussink (2016). Effecten bodem- en structuurverbeteraars. Onderzoek op klei- en zandgrond 2010-2015; Eindrapportage. PPO publicatienummer: 693. Projectnummer: 3250159600. Praktijkonderzoek Plant \& Omgeving, onderdeel van Wageningen UR, Business Unit Akkerbouw, Groene Ruimte en Vollegrondsgroenten, Lelystad.

- Van Balen, D.J.M., C.G. Topper, W.C.A. van Geel, J.J. de Haan, W. van den Berg, M.J.G. de Haas \& D.W. Bussink (2016). Effecten bodem- en structuurverbeteraars. Onderzoek op klei- en zandgrond 2010-2015; Eindrapportage. PPO publicatienummer: 693. Projectnummer: 3250159600. 
Praktijkonderzoek Plant \& Omgeving, onderdeel van Wageningen UR, Business Unit Akkerbouw, Groene Ruimte en Vollegrondsgroenten, Lelystad.

- Van Geel, W.C.A., \& J.J. Schröder (2007). Stikstofwerking van gewasrestencomposten in suikerbieten. PPO nr. 32500331, PPO_AGV, Lelystad.

\section{Wintertarwe}

- Bussink W, Doppenberg G, Van den Berg W, Van Wijk K (2014). Naar een nieuw fosfaatbemestingsadvies in de akkerbouw. Masterplan Mineralenmanagement, Productschap Akkerbouw, Zoetermeer, 43 pp.

- Floot H (2005). Wintertarwerassen Noordelijke klei, KW 0503, SPNA.

- Floot H (2007). EU-wintertarwerassen, EH 0707 - KW 0704, SPNA.

- Floot H (2008). EU-wintertarwerassen 2008, EH 0807 - KW 0803, SPNA.

- Floot H W G (2002). Kwaliteitswintertarwerassen, EH 0209, SPNA.

- Floot H W G (2002). Wintertarwerassen Noordelijke klei, KW 0205, SPNA.

- Floot H W G (2003). Kwaliteitswintertarwerassen, EH 0307, SPNA.

- Floot H W G (2004). Kwaliteitswintertarwerassen EH0410, SPNA.

- Floot H W G (2004). Wintertarwerassen Noordelijke klei, KW 0403, SPNA.

- Floot H W G (2005). Kwaliteitswintertarwerassen EH0510, SPNA.

- Floot H W G (2006). 3 EU-wintertarwerassen, EH 0610 - KW 0603, SPNA.

- Hofstee A, Van 't Westeinde J (2013). Rassenonderzoek EU Wintertarwe 2013, SPNA.

- Interne data WUR-OT.

- Otter W S, Van 't Westeinde J (2011). Rassenonderzoek EU wintertarwe 2011 - SPNA.

- Otter W S, Van 't Westeinde J (2012). Rassenonderzoek EU wintertarwe 2012 - SPNA.

- Otter W S, Van 't Westeinde J (2014). Rassenonderzoek EU wintertarwe 2014 - SPNA.

- Paauw J G M, Van Balen D, De Haan J J, De Haas M J G, Van der Draai H, Bussink D W (2013). Effecten bodem- en structuurverbeteraars. Onderzoek op klei-, zand- en dalgrond 2012. PPO nr. 481, Praktijkonderzoek Plant \& Omgeving, onderdeel van Wageningen UR, Business Unit Akkerbouw, Groene Ruimte en Vollegrondsgroenten, Lelystad.

- Schröder J J, Steenhuizen J W, Jansen A G, Fraters B, Siepel A (2003). Opbrengst, mineralenverlies en bodemvruchtbaarheid van een biologisch akkerbouwbedrijf in relatie tot bemestingsniveaus. Resultaten van het Ecologisch Proefbedrijf Dr H.J. Lovinkhoeve 1996 - 2002. Plant Research International B.V., Wageningen, Rapport 69.

- Topper C G, Van Balen D, Verstegen H, De Haan J J, De Haas M J G, Doppenberg G J, Bussink D W (2013). Effecten bodem- en structuurverbeteraars. Onderzoek op klei-, zand- en dalgrond. Resultaten 2013. PPO nr. 597, Praktijkonderzoek Plant \& Omgeving, onderdeel van Wageningen UR, Business Unit Akkerbouw, Groene Ruimte en Vollegrondsgroenten, Lelystad.

- Van Balen D J M, Topper C G, Van Geel W C A, De Haan J J, Van den Berg W, De Haas M J G, Bussink D W (2016). Effecten bodem- en structuurverbeteraars. Onderzoek op klei- en zandgrond 2010-2015; Eindrapportage. PPO publicatienummer: 693. Projectnummer: 3250159600.

Praktijkonderzoek Plant \& Omgeving, onderdeel van Wageningen UR, Business Unit Akkerbouw, Groene Ruimte en Vollegrondsgroenten, Lelystad.

- Van den Brink L (2010). Cultuur- en gebruikswaarde onderzoek wintertarwe 2009, Praktijkonderzoek Plant \& Omgeving.

- Van den Brink L (2011). Cultuur- en gebruikswaarde onderzoek wintertarwe 2010, Praktijkonderzoek Plant \& Omgeving.

- Van den Brink L (2012). Cultuur- en gebruikswaarde onderzoek wintertarwe 2011, Praktijkonderzoek Plant \& Omgeving.

- Van den Brink L (2013). Cultuur- en gebruikswaarde onderzoek wintertarwe 2012, Praktijkonderzoek Plant \& Omgeving.

- Van den Brink L (2014). Cultuur- en gebruikswaarde onderzoek wintertarwe 2013, Praktijkonderzoek Plant \& Omgeving.

- Van den Brink L (2015). Cultuur- en gebruikswaarde onderzoek wintertarwe 2014, Praktijkonderzoek Plant \& Omgeving.

- Van den Brink L (2016). Cultuur- en gebruikswaarde onderzoek wintertarwe 2015, Praktijkonderzoek Plant \& Omgeving.

- Van den Brink L (2016). Cultuur- en gebruikswaarde onderzoek wintertarwe 2016, Wageningen University \& Research. 
- Van den Brink L (2018). Cultuur- en gebruikswaarde onderzoek wintertarwe 2017, Wageningen University \& Research.

- Van den Brink L (2019). Cultuur- en gebruikswaarde onderzoek wintertarwe 2018, Wageningen University \& Research.

- Van Geel W, Van den Berg W, Van Dijk W, Wustman R (2012). Aanvullend onderzoek mineralenconcentraten 2009-2011 op bouwland en grasland. Samenvatting van de resultaten uit de veldproeven en bepaling van de stikstofwerking. PPO 476, PPO-AGV, Lelystad.

- Van 't Westeinde J (2012). Opbrengsten EU wintertarwe rassenproef SPNA 2012 (tabel).

- Veldman W S, et al. (2008). Wintertarwe CGO 2008 Concept deel 1, SPNA Agro research.

\section{Zaaiui}

- Van den Brink L, Dekker P H M, Van den Berg W (2007). Optimale N-bemesting zaaiuien. PPO AGV, Lelystad, Projectrapport 3250078400.

- Van den Brink L, Dekker P H M en Van den Berg W (2009). Aanpassing N-bemestingsadvies zaaiuien. Projectrapport 3250078408.

- Bussink W, G Doppenberg, W Van den Berg, K Van Wijk (2014). Naar een nieuw fosfaatbemestingsadvies in de akkerbouw. Masterplan Mineralenmanagement, Productschap Akkerbouw, Zoetermeer, 43 pp.

- Interne data WUR-OT.

- Interne data WUR Open Teelten, project BASIS.

- Malda J T, Rutgers R (2012). Fosfaat (rijen)bemesting in zaaiuien. Meerjarige onderzoekresultaten naar het effect van Avail, APP volvelds en fosfaatrijenbemesting met vloeibare meststoffen in de teelt van zaaiuien op kleigronden in 2010 t/m 2012. 12-2813 Productschap Akkerbouw, Altic, Dronten.

- Malda J T, R. Rutgers R (2013). Bemestingsonderzoek zaaiuien. Meerjarige onderzoeksresultaten naar bemestingsstrategieën om tot een hogere $\mathrm{N}$-en P-efficiëntie te komen in de teelt van zaaiuien op een kleigrond in Zuidwest Nederland. Projectnr. 3828 Productschap Akkerbouw, Altic, Dronten.

- Paauw J G M (2008). Fosfaatonderzoek Powerstart in zaaiuien 2008 op kleigrond. PPO nr. 3250109400, PPO-AGV, Lelystad (geen openbaar rapport).

- Van de Broek R 2009 t/m 2013. Invloed van het type Kalibemesting op de smaak van uien (Vertrouwelijk rapporten).

- Van Geel W, Evenhuis B, Topper C (2018). Effect van nutriënten op kwaliteit en weerbaarheid. Verslag van onderzoek naar effect kali in 2017. Uireka rapport nummer 2018-04.

- Van Geel W, Evenhuis B, Topper C (2019). Effect van nutriënten op kwaliteit en weerbaarheid. Verslag van de veldproef in 2018. Uireka rapport nummer 2019-01.

- Schröder J J, Steenhuizen J W, Jansen A G, Fraters B, Siepel A (2003). Opbrengst, mineralenverlies en bodemvruchtbaarheid van een biologisch akkerbouwbedrijf in relatie tot bemestingsniveaus. Resultaten van het Ecologisch Proefbedrijf Dr H J Lovinkhoeve 1996 - 2002. Plant Research International B.V., Wageningen, Rapport 69.

- Topper C G, Van Balen D, Verstegen H, De Haan J J, De Haas M J G, Doppenberg G J, Bussink D W (2014). Effecten bodem- en structuurverbeteraars. Onderzoek op klei-, zand- en dalgrond. Resultaten 2014. PPO nr. 597, Praktijkonderzoek Plant \& Omgeving, onderdeel van Wageningen UR, Business Unit Akkerbouw, Groene Ruimte en Vollegrondsgroenten, Lelystad.

- Van Balen D J M, Topper C G, Van Geel W C A, De Haan J J, Van den Berg W, De Haas M J G, Bussink D W (2016). Effecten bodem- en structuurverbeteraars. Onderzoek op klei- en zandgrond 2010-2015; Eindrapportage. PPO publicatienummer 693, Projectnummer 3250159600.

Praktijkonderzoek Plant \& Omgeving, onderdeel van Wageningen UR, Business Unit Akkerbouw, Groene Ruimte en Vollegrondsgroenten, Lelystad.

- Van Geel W, Evenhuis B, Topper C (2019). Effect van nutriënten op kwaliteit en weerbaarheid. Verslag van de veldproef in 2018. Uireka rapport nummer: 2019-01.

- Dekker P H M, Paauw J G M, Van den Berg W (2008). Biogas Flevoland. Verslag van het veldonderzoek in 2007 naar de landbouwkundige waarde van covergiste mest. PPO nr. 3251046400, PPO-AGV, Lelystad.

\section{Zomergerst}

- Floot H W G en Venhuizen A (2000). Zomergerstrassen EH 897, KW 396 - SPNA.

- Floot H W G en Venhuizen A (2001). Zomergerstrassen EH 0008 KW 0012 - SPNA. 
- Floot H W G en Venhuizen A (2002). Zomergerstrassen EH 0110, KW 0109 - SPNA.

- Floot H W G en Venhuizen A (2003). Zomergerstrassen EH 0210, KW 0207 - SPNA.

- Floot H W G en Venhuizen A (2004). Zomergerstrassen EH 0308, KW 0304 - SPNA.

- Floot H W G en Venhuizen A (2005). Zomergerstrassen EH 0411, KW 0404 - SPNA.

- SPNA (2007). (anoniem) Het cultuur- en gebruikswaarde onderzoek in zomergerst - GEMIDDELDEN.

- Interne data WUR-OT.

- Interne data WUR Open Teelten, project BASIS.

- Pauw J G M, Van Balen D, De Haan J J, De Haas M J G, Van der Draai H, Bussink D W (2010). Effecten bodem- en structuurverbeteraars. Onderzoek op klei-, zand- en dalgrond 2010. PPO projectnr. 3250159600, Praktijkonderzoek Plant \& Omgeving, onderdeel van Wageningen UR, Business Unit Akkerbouw, Groene Ruimte en Vollegrondsgroenten, Lelystad.

- Van Balen D J M, Topper C G, Van Geel W C A, De Haan J J, Van den Berg W, De Haas M J G, Bussink D W (2016). Effecten bodem- en structuurverbeteraars. Onderzoek op klei- en zandgrond 2010-2015; Eindrapportage. PPO publicatienummer: 693. Projectnummer: 3250159600.

Praktijkonderzoek Plant \& Omgeving, onderdeel van Wageningen UR, Business Unit Akkerbouw, Groene Ruimte en Vollegrondsgroenten, Lelystad.

- Timmer R D, Booij J A, Van den Berg W (2020). Optimalisatie eiwitgehalte brouwgerst. Resultaten onderzoek 2017-2019. Rapport WPR-826, Wageningen University \& Research.

- Timmer R D et al. (2009). Cultuur-en gebruikswaarde onderzoek zomergerst 2009, Praktijkonderzoek Plant \& Omgeving B.V.

- Timmer R D et al. (2010). Cultuur-en gebruikswaarde onderzoek zomergerst 2010, Wageningen UR.

- Timmer R D et al. (2011). Cultuur-en gebruikswaarde onderzoek zomergerst 2011, Wageningen UR.

- Timmer R D et al. (2012). Cultuur-en gebruikswaarde onderzoek zomergerst 2012, Wageningen UR.

- Timmer R D et al. (2013). Cultuur-en gebruikswaarde onderzoek zomergerst 2013, Wageningen UR.

- Timmer R D et al. (2014). Cultuur-en gebruikswaarde onderzoek zomergerst 2014, Wageningen UR.

- Timmer R D et al. (2015). Cultuur-en gebruikswaarde onderzoek zomergerst 2015, Wageningen UR.

- Timmer R D et al. (2016). Cultuur-en gebruikswaarde onderzoek zomergerst 2016, Wageningen University \& Research.

- Timmer R D et al. (2017). Cultuur-en gebruikswaarde onderzoek zomergerst 2017, Wageningen University \& Research.

- Timmer R D et al. (2018). Cultuur-en gebruikswaarde onderzoek zomergerst 2018, Wageningen University \& Research.

- Veldman, et al. (2008). Eindrapportage CGO zomergerst 2008, SPNA Agro research

- SPNA (2006). Zomergerstrassen demo ism Agrifirm.

- Van Geel W, Van den Berg W, Van Dijk W, Wustman R (2012). Aanvullend onderzoek mineralenconcentraten 2009-2011 op bouwland en grasland. Samenvatting van de resultaten uit de veldproeven en bepaling van de stikstofwerking. PPO 476, PPO-AGV, Lelystad.

- Van Geel W C A, Dekker P H M, De Groot W J M, Van den Akker J J H, Floot H W G (2007). Structuurherstellend vermogen van groenbemesters. Verslag van veldproeven in 2005-2006 te Lelystad en Kollumerwaard. PPO-projectrapport nr. 510492, PPO-AGV, Lelystad.

- Van Geel W C A, Dekker P H M, De Groot W J M (2009). Verbetering structuur ondergrond. Verslag van veldonderzoek op een zavelgrond te Lelystad 2006-2009. PPO nr. 3250055100, PPO-AGV, Lelystad

- Slabbekoorn H, Dekker P (2008). Effect van toepassing effectieve micro-organismen in zomergerst 2007. PPO projectnr. 3250061900, PPO-AGV, Westmaas.

- Wijnholds K H (2004). Stikstofbemesting en groeiregulatie in zomergerst 2004. PPOprojectrapportnr. 510451, PPO-AGV, Valthermond.

- Wijnholds K H (2005). Stikstofbemesting en groeiregulatie in zomergerst 2005. PPOprojectrapportnr. 500123, PPO-AGV, Valthermond.

\section{Zomertarwe}

- Interne data WUR Open Teelten, project BASIS.

- Pauw, J.G.M., D. van Balen, J.J. de Haan, M.J.G. de Haas, H. van der Draai \& D.W. Bussink (2010). Effecten bodem- en structuurverbeteraars. Onderzoek op klei-, zand- en dalgrond 2010. PPO projectnr. 3250159600, Praktijkonderzoek Plant \& Omgeving, onderdeel van Wageningen UR, Business Unit Akkerbouw, Groene Ruimte en Vollegrondsgroenten, Lelystad. 
- Van Balen, D.J.M., C.G. Topper, W.C.A. van Geel, J.J. de Haan, W. van den Berg, M.J.G. de Haas \& D.W. Bussink (2016). Effecten bodem- en structuurverbeteraars. Onderzoek op klei- en zandgrond 2010-2015; Eindrapportage. PPO publicatienummer: 693. Projectnummer: 3250159600.

Praktijkonderzoek Plant \& Omgeving, onderdeel van Wageningen UR, Business Unit Akkerbouw, Groene Ruimte en Vollegrondsgroenten, Lelystad.

- Schröder J.J., J.W. Steenhuizen, A.G. Jansen, B. Fraters \& A. Siepel (2003). Opbrengst, mineralenverlies en bodemvruchtbaarheid van een biologisch akkerbouwbedrijf in relatie tot bemestingsniveaus. Resultaten van het Ecologisch Proefbedrijf Dr H.J. Lovinkhoeve 1996 - 2002. Plant Research International B.V., Wageningen, Rapport 69.

- Timmer et al., (2007, november). Optimale N-bemesting zomertarwe Resultaten onderzoek 2007, Praktijkonderzoek Plant \& Omgeving B.V.

- Timmer et al., (2008, December). Optimale N-bemesting zomertarwe Resultaten onderzoek 2008, Praktijkonderzoek Plant \& Omgeving B.V.

- Timmer, et al., (2012, november). cultuur- en gebruikswaarde onderzoek zomertarwe 2012, Praktijkonderzoek Plant \& Omgeving.

- Timmer, et al., (2013, november). cultuur- en gebruikswaarde onderzoek zomertarwe 2013, Praktijkonderzoek Plant \& Omgeving.

- Topper, C.G., D. van Balen, H. Verstegen, J.J. de Haan, M.J.G. de Haas, G.J. Doppernberg \& D.W. Bussink (2013). Effecten bodem- en structuurverbeteraars. Onderzoek op klei-, zand- en dalgrond. Resultaten 2013. PPO nr. 597, Praktijkonderzoek Plant \& Omgeving, onderdeel van Wageningen UR, Business Unit Akkerbouw, Groene Ruimte en Vollegrondsgroenten, Lelystad.

- Van Balen, D.J.M., C.G. Topper, W.C.A. van Geel, J.J. de Haan, W. van den Berg, M.J.G. de Haas \& D.W. Bussink (2016). Effecten bodem- en structuurverbeteraars. Onderzoek op klei- en zandgrond 2010-2015; Eindrapportage. PPO publicatienummer: 693. Projectnummer: 3250159600.

Praktijkonderzoek Plant \& Omgeving, onderdeel van Wageningen UR, Business Unit Akkerbouw, Groene Ruimte en Vollegrondsgroenten, Lelystad. 


\section{Bijlage 2 Waardering van de fosfaat- toestand van de bodem op basis van Pw-getal}

Tabel B2.1 Waardering van de fosfaattoestand van de bodem op basis van Pw-getal (1970) (bron: CBAV, 2019; link).

\begin{tabular}{lc} 
Waardering & Pw-getal \\
Zeer laag & $<11$ \\
\hline Laag & $11-20$ \\
\hline Voldoende & $21-30$ \\
\hline Ruim voldoende & $31-45$ \\
\hline Vrij hoog & $46-60$ \\
\hline Hoog & $>60$ \\
\hline
\end{tabular}




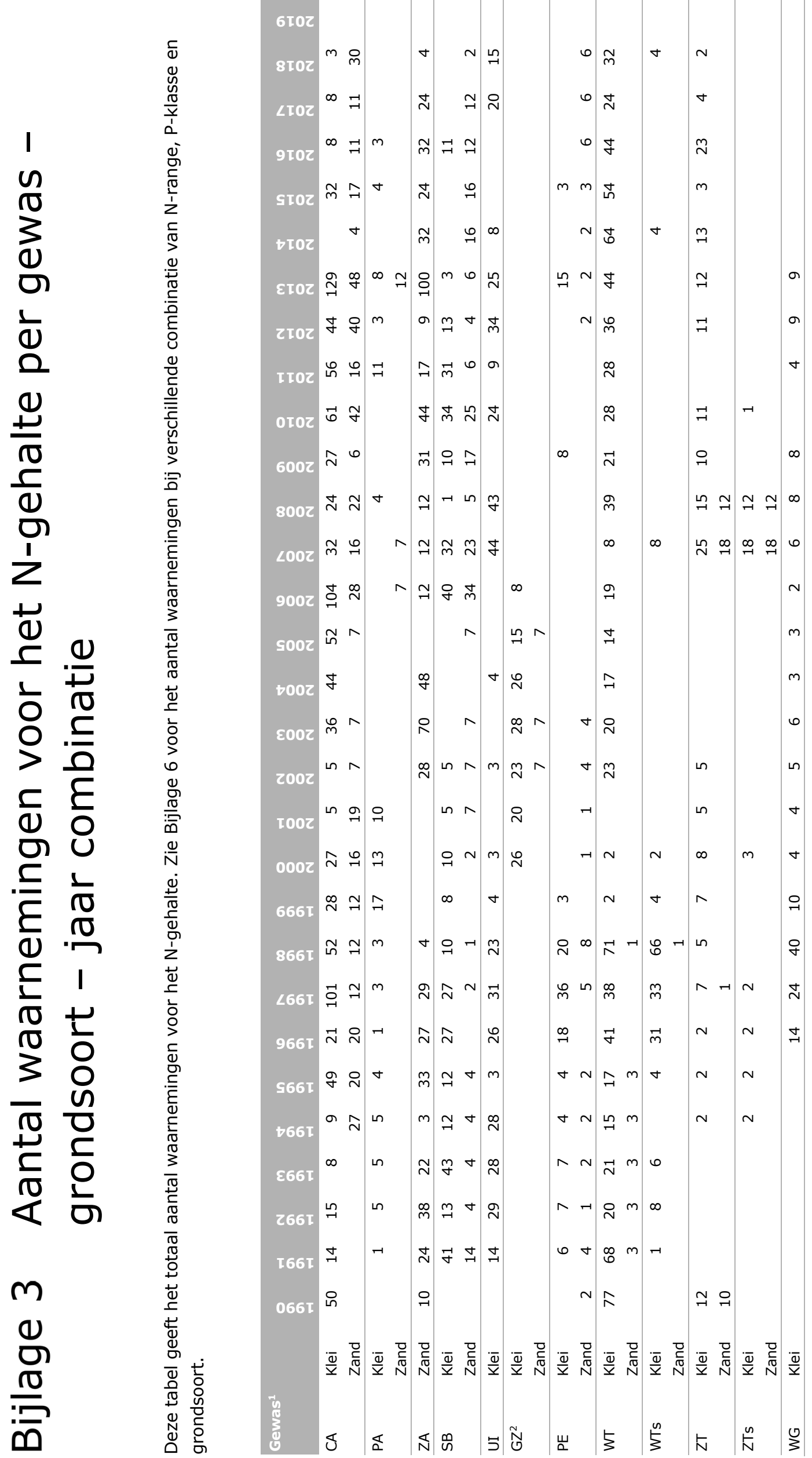

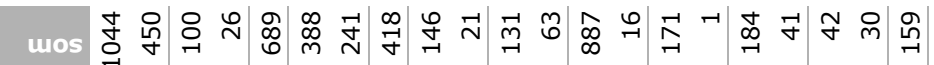




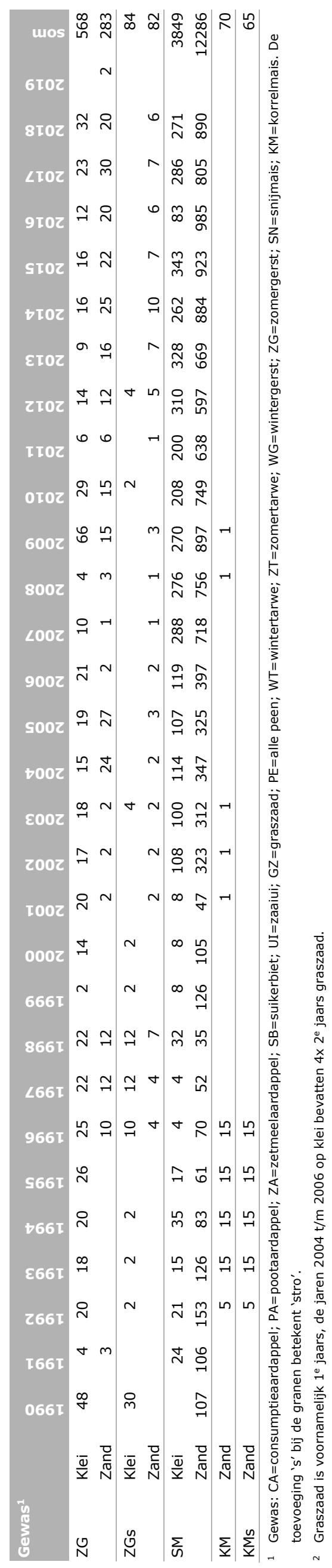




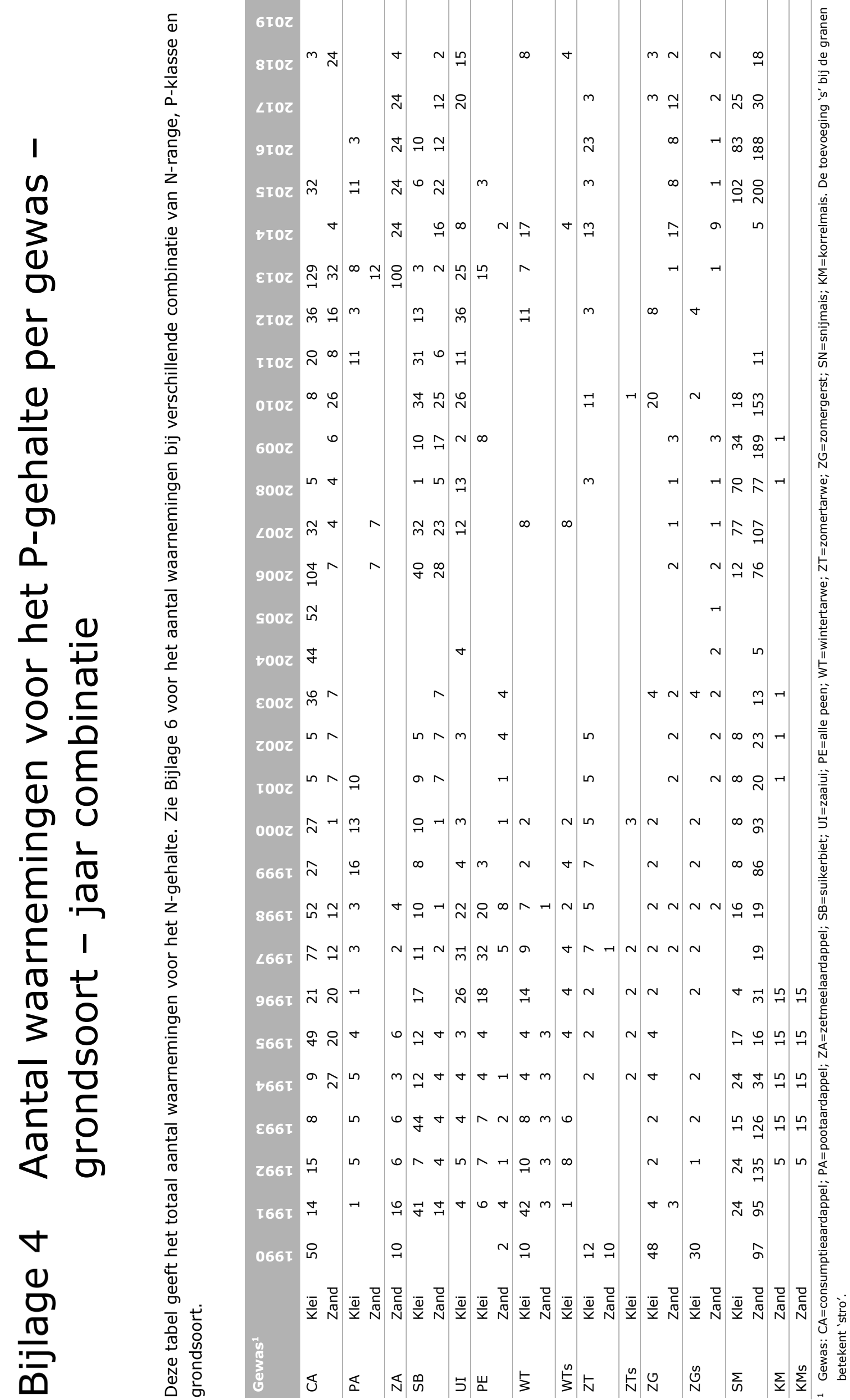

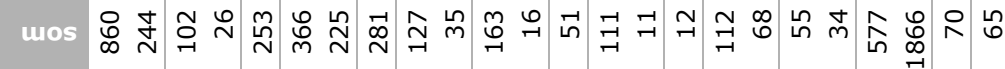




\section{Bijlage 5 Spreiding in gehalten en opbrengst bij verschillende bemesting}

Deze bijlage geeft een overzicht van gemiddelde en spreiding in $\mathrm{N}$ - en P-gehalten en opbrengsten voor verschillende selecties naar:

- P-klasse (midden, verbreed, alle data)

- N-range (links, rechts, smal, breed)

- Grondsoort (klei, zand, klei+zand)

De boxplot figuren geven de mediane waarde (het horizontale lijntje in de box), het $25 \%$-kwantiel (onderzijde van de box) en het $75 \%$-kwantiel (bovenzijde van de box) en met de lijntjes de minimale en maximale waarde.

Het verschil tussen $\mathrm{N}$-range links en rechts geeft een indicatie of $\mathrm{N}$-bemesting een effect heeft op het $\mathrm{N}$-gehalte of de versopbrengst. Bij een duidelijk effect van $\mathrm{N}$-bemesting kan het beste geselecteerd worden op N-range smal: bemesting dichtbij het $\mathrm{N}$-advies. Is er geen duidelijk effect dan kan de $\mathrm{N}$-range breder genomen worden om het gehalte op meer waarnemingen te baseren.

Figuren voor de verschillende gewassen staan in de volgorde:

- Consumptieaardappelen

- Pootaardappelen

- Zetmeelaardappelen

- Suikerbieten

- Zaaiuien

- Wintertarwe

- Zomertarwe

- Wintergerst

- Zomergerst

- Was- en winterpeen

- Snijmais

- Korrelmais 


\section{Consumptieaardappelen - N gehalte}
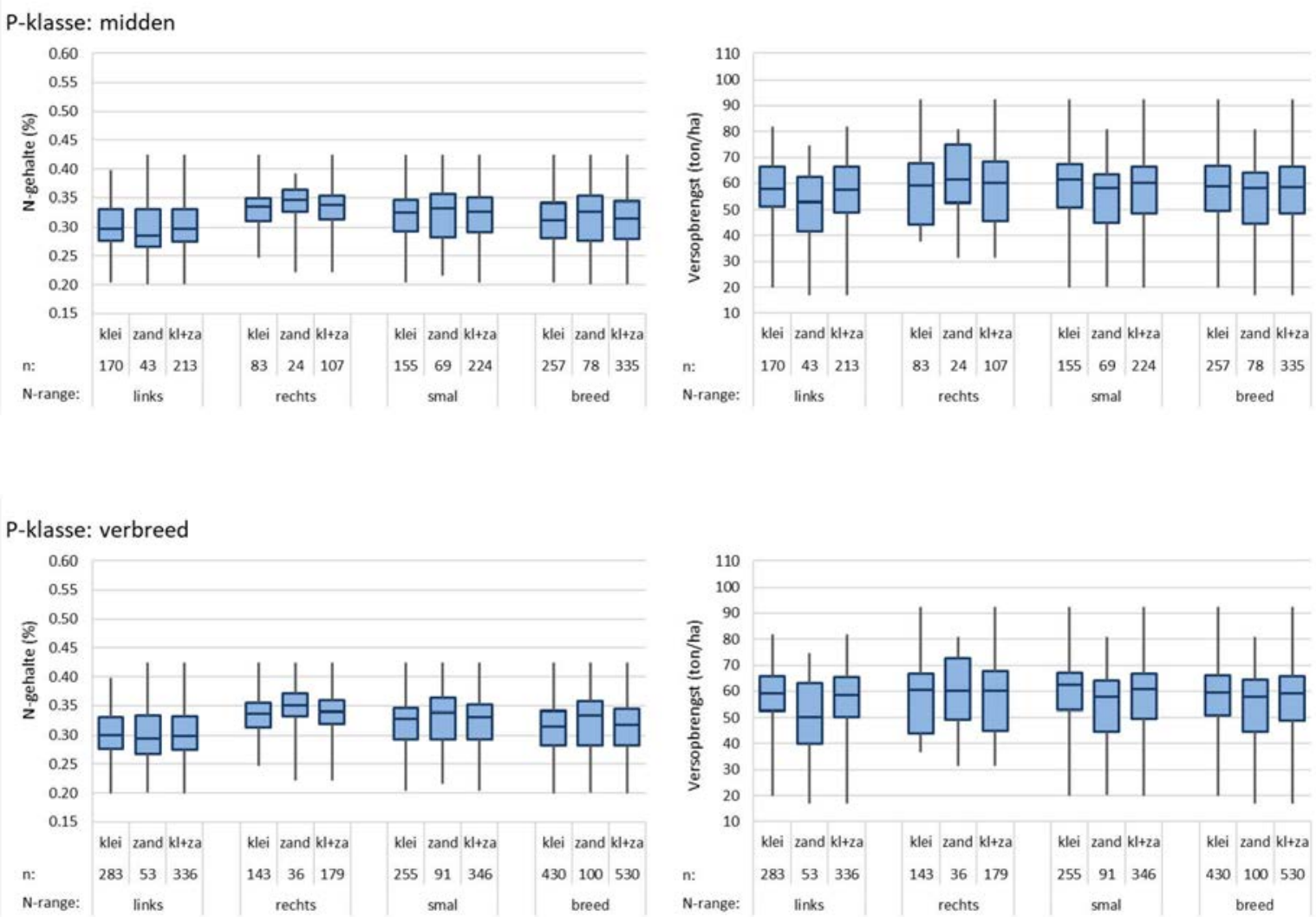

\section{P-klasse: alle data}
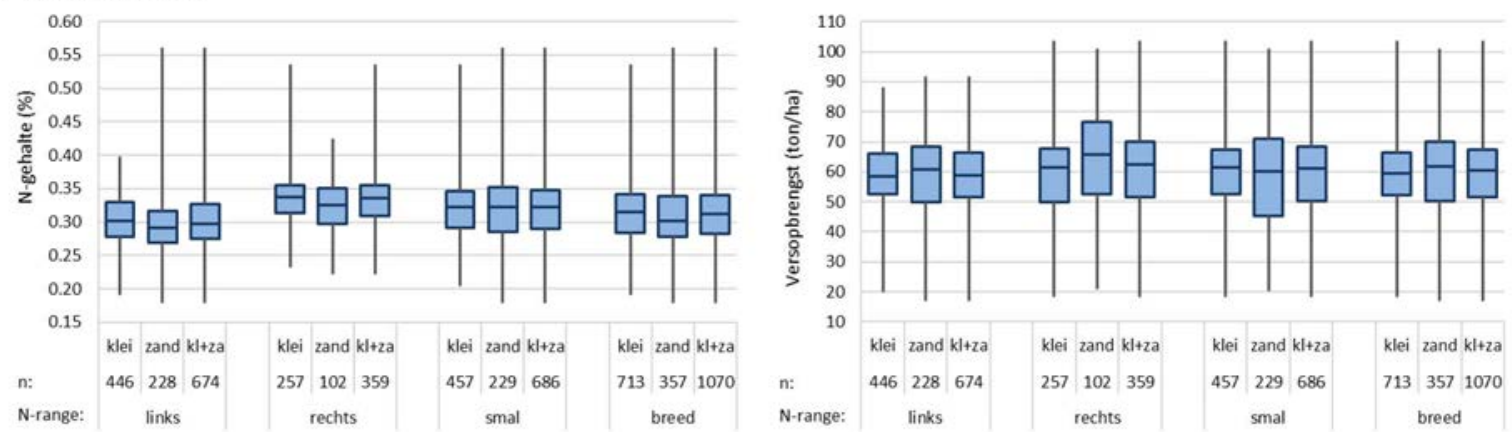


\section{Consumptieaardappelen - P gehalte}
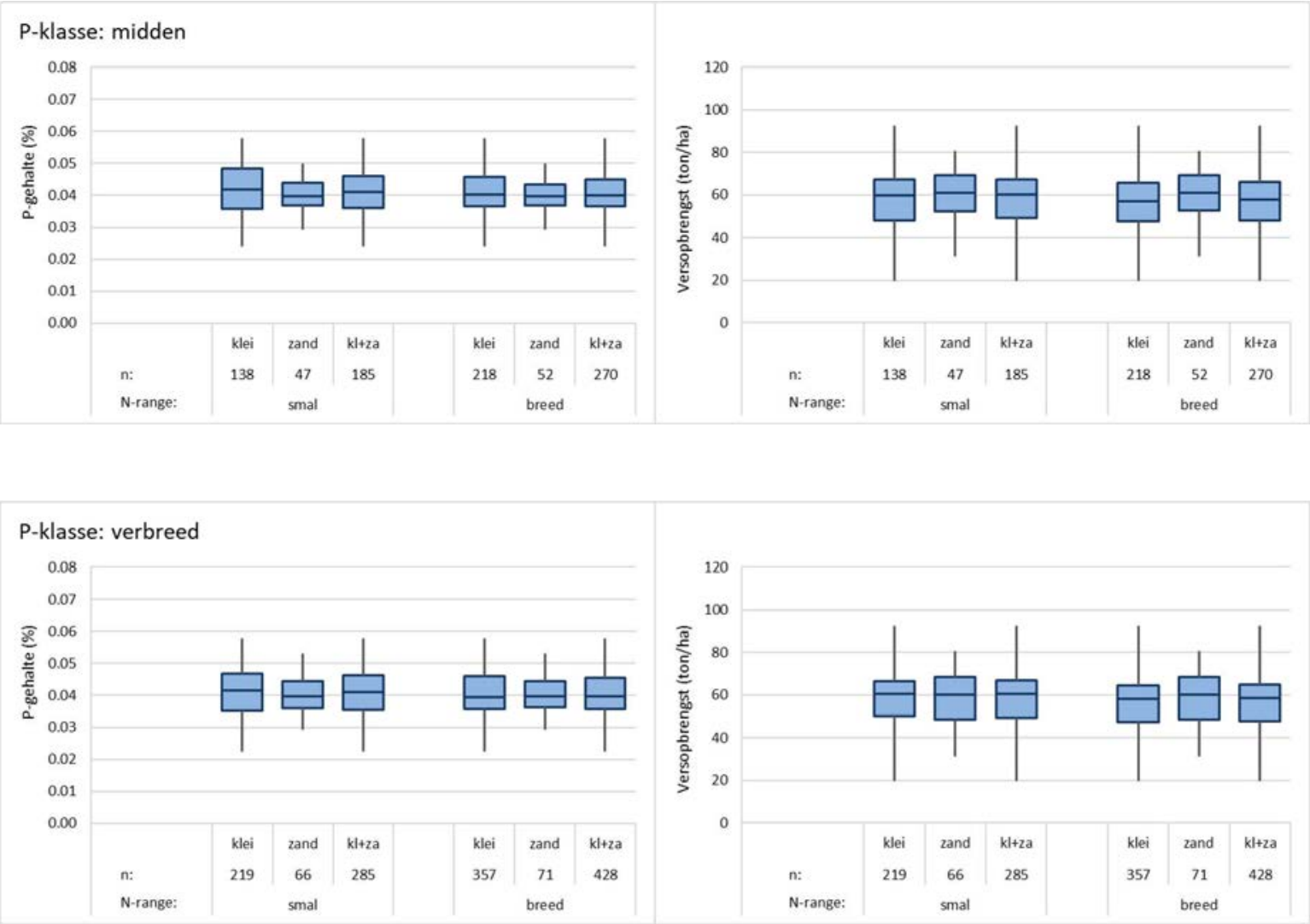

P-klasse: alle data

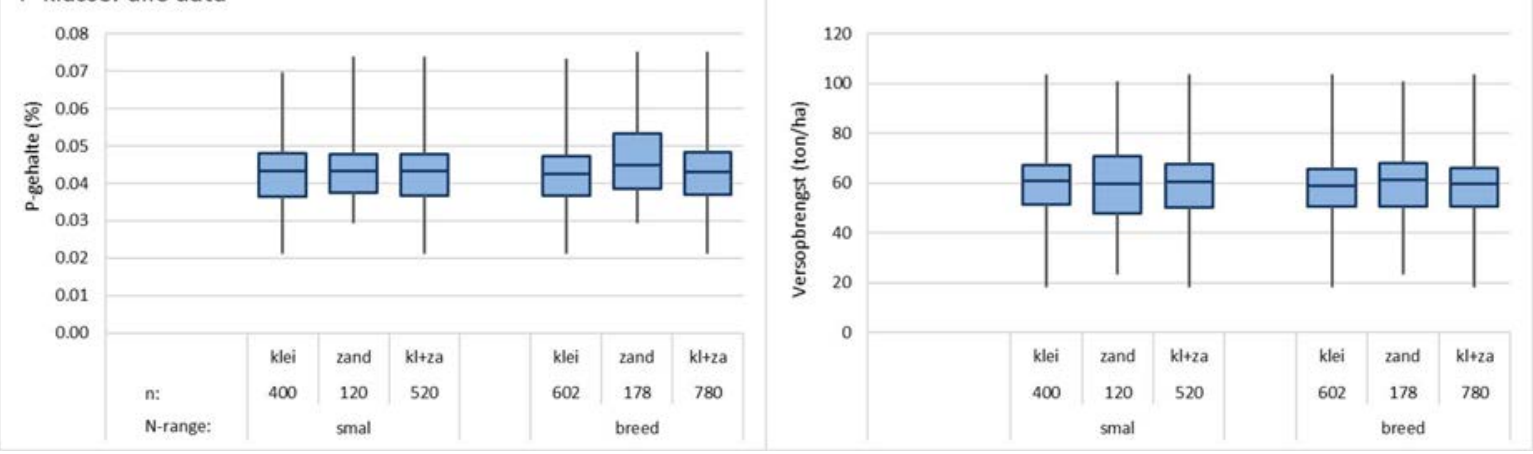




\section{Pootaardappelen - N gehalte}

P-klasse: midden

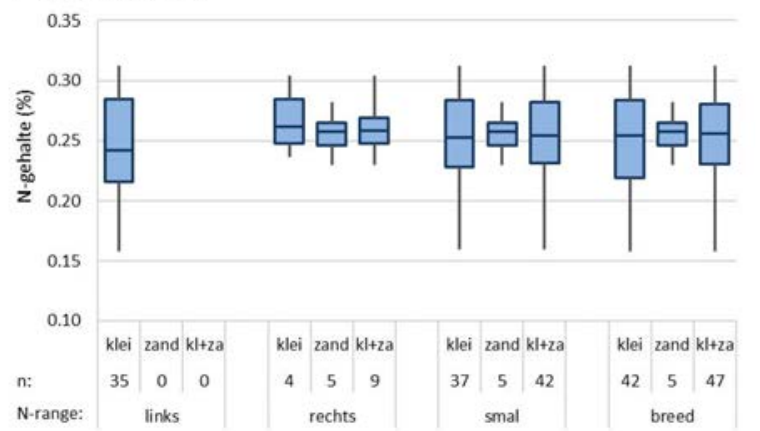

P-klasse: verbreed

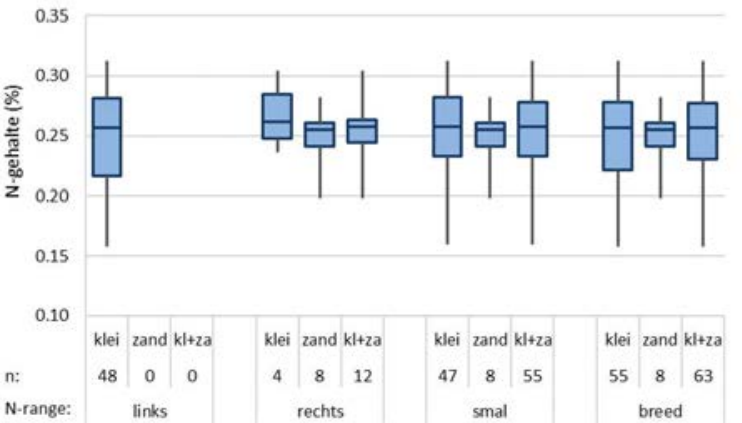

P-klasse: alle data

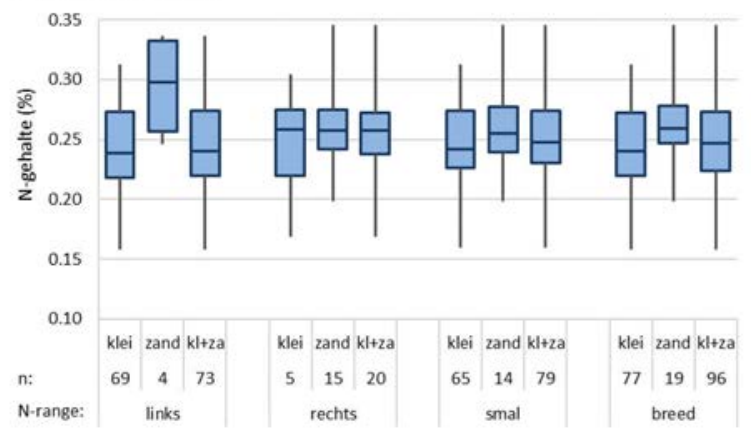

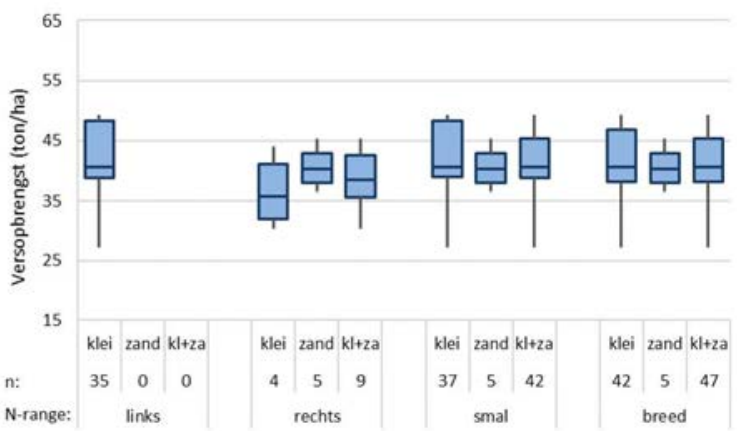

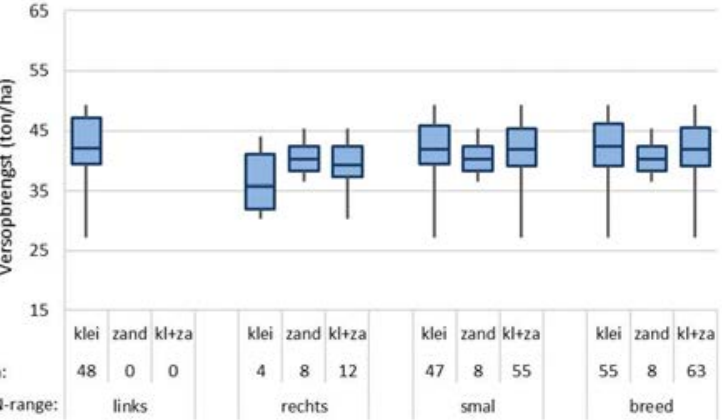




\section{Pootaardappelen - P gehalte}
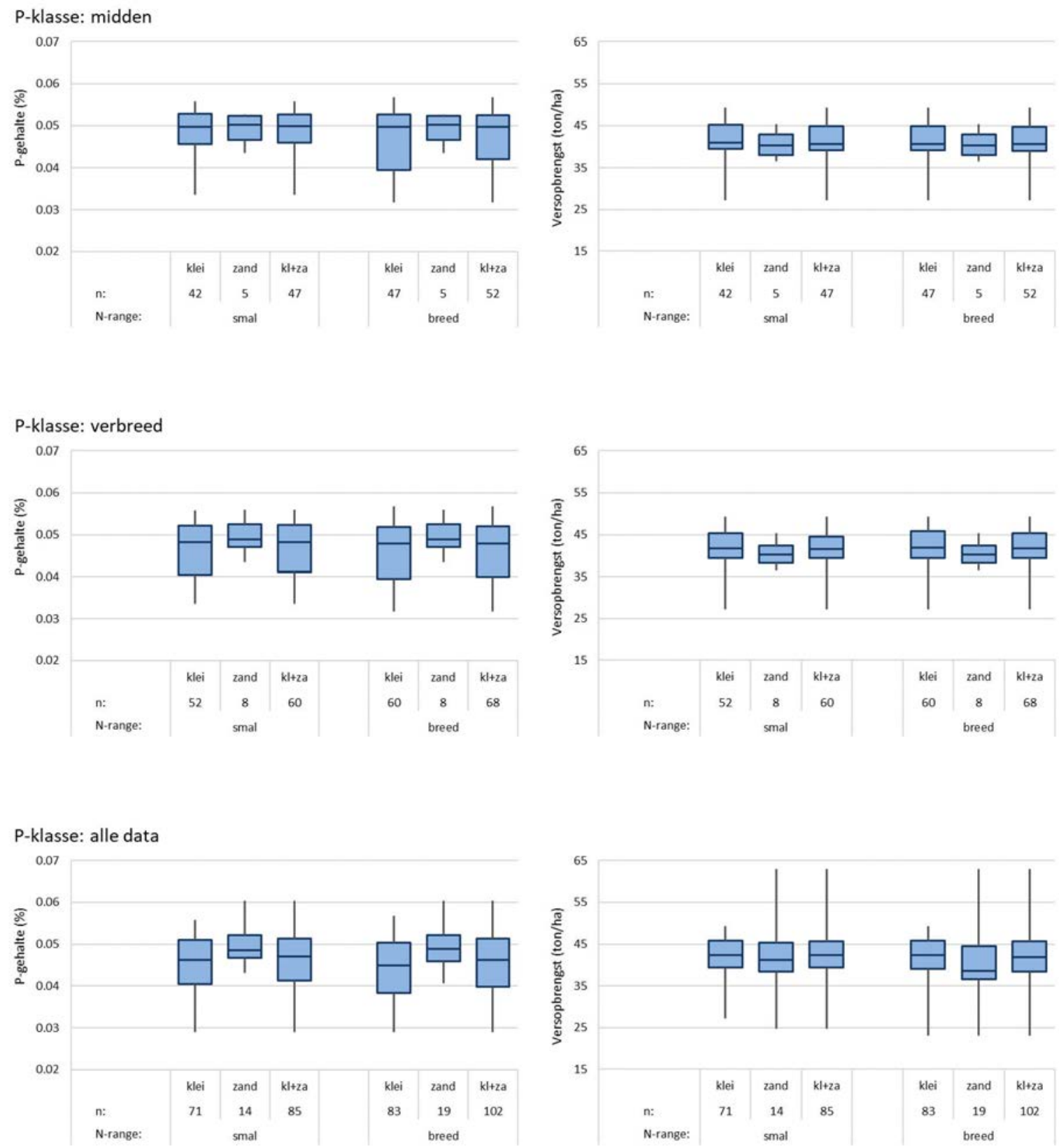


\section{Zetmeelaardappelen - N gehalte}

P-klasse: midden

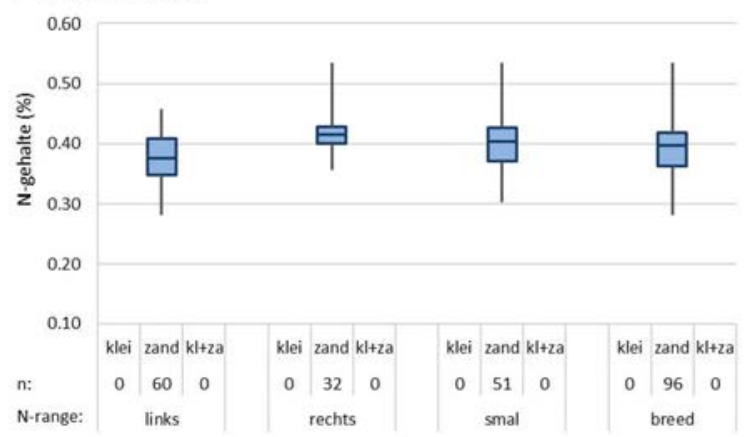

P-klasse: verbreed

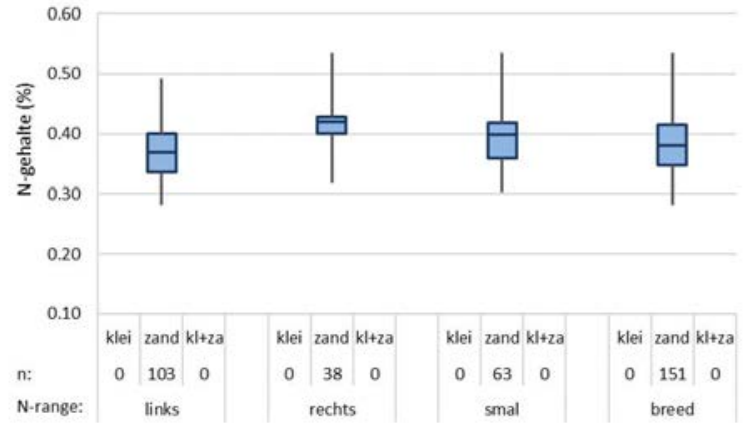

P-klasse: alle data

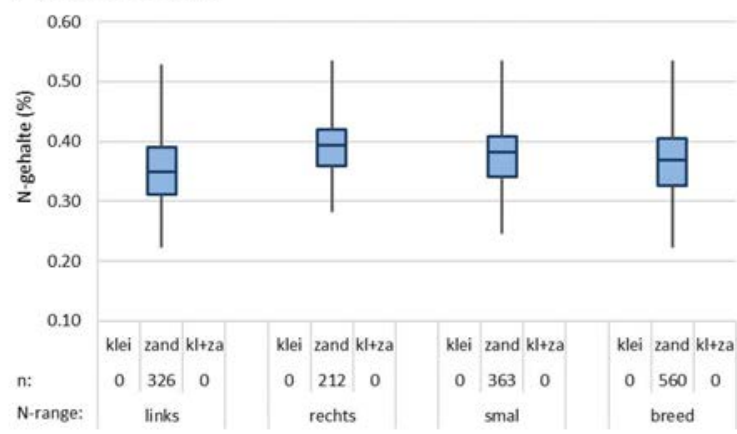

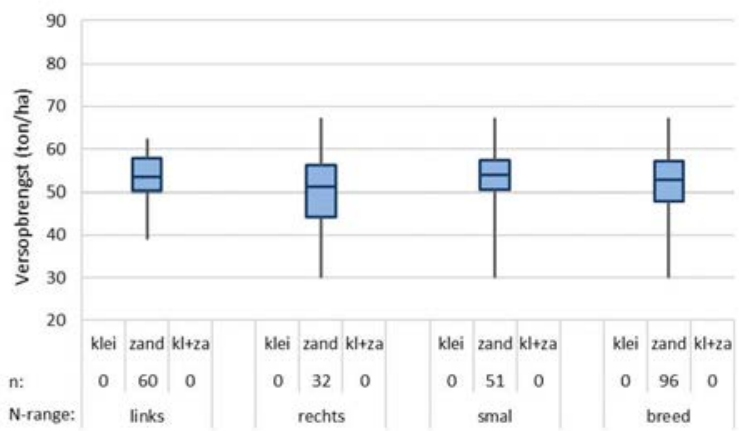
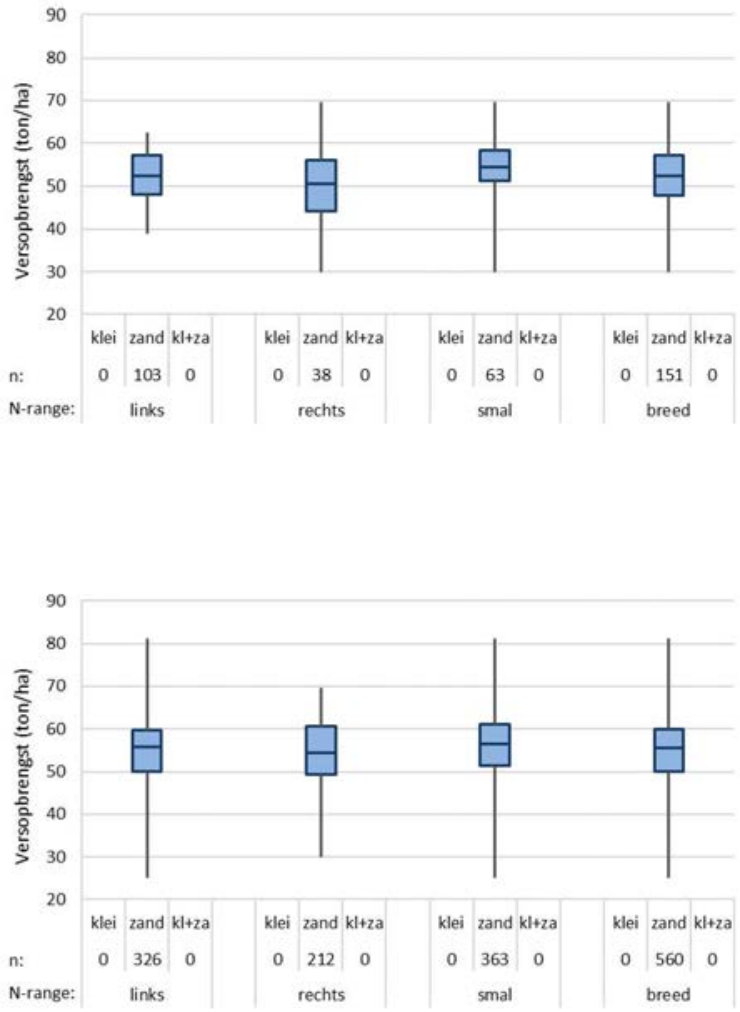


\section{Zetmeelaardappelen - P gehalte}
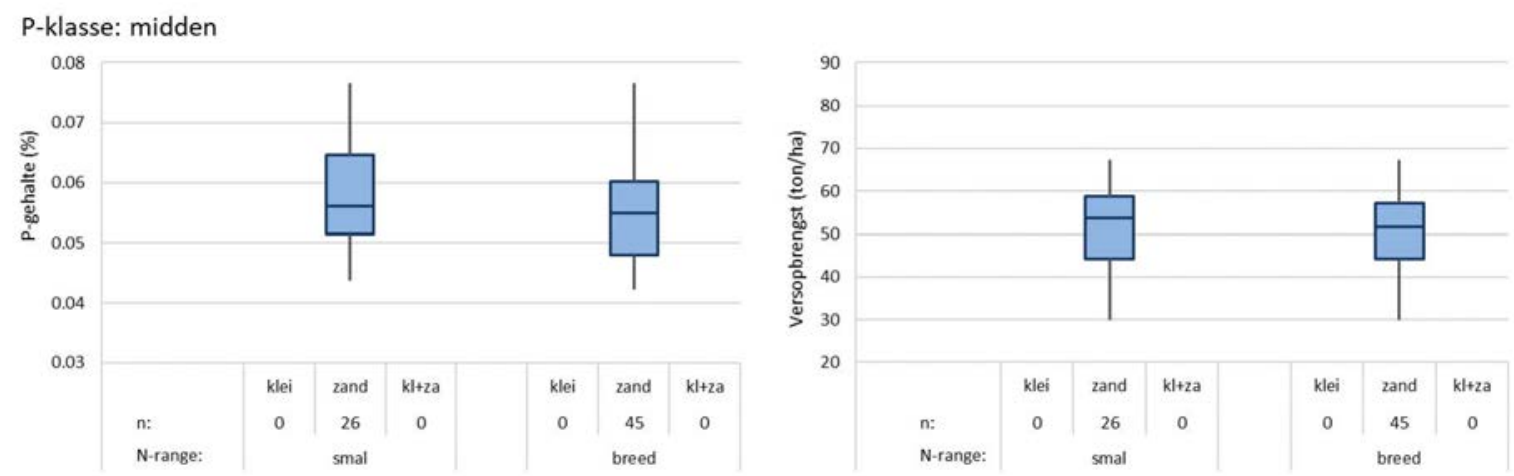

P-klasse: verbreed
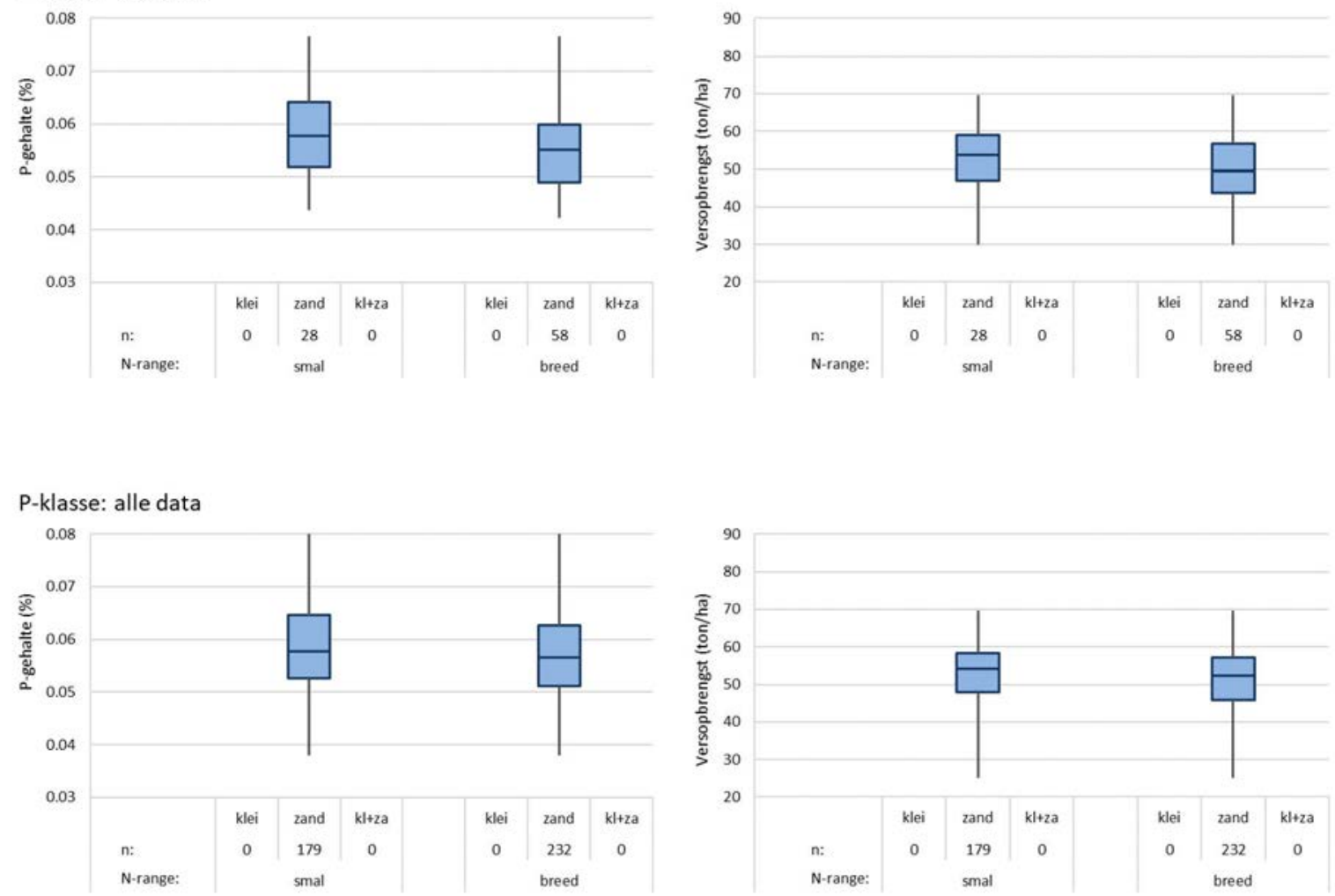


\section{Suikerbieten - $\mathbf{N}$ gehalte}

P-klasse: midden

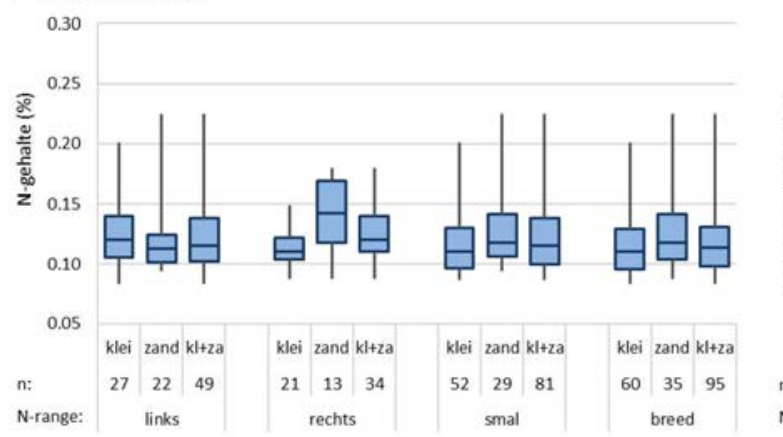

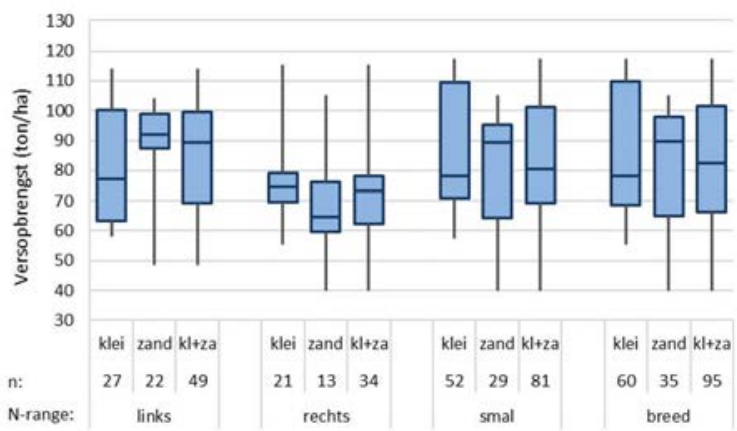

P-klasse: verbreed
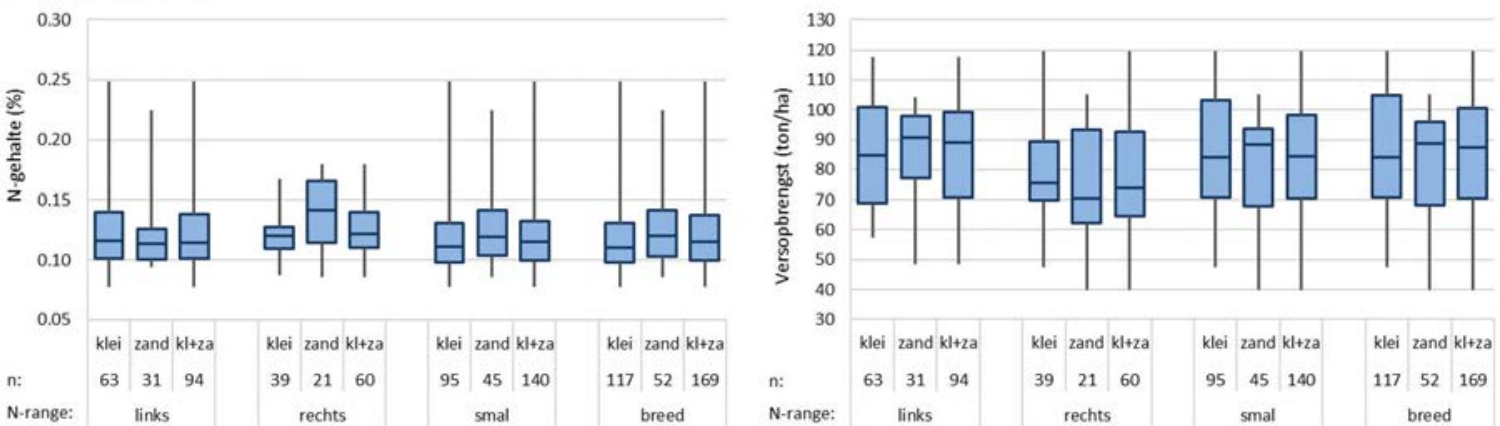

P-klasse: alle data
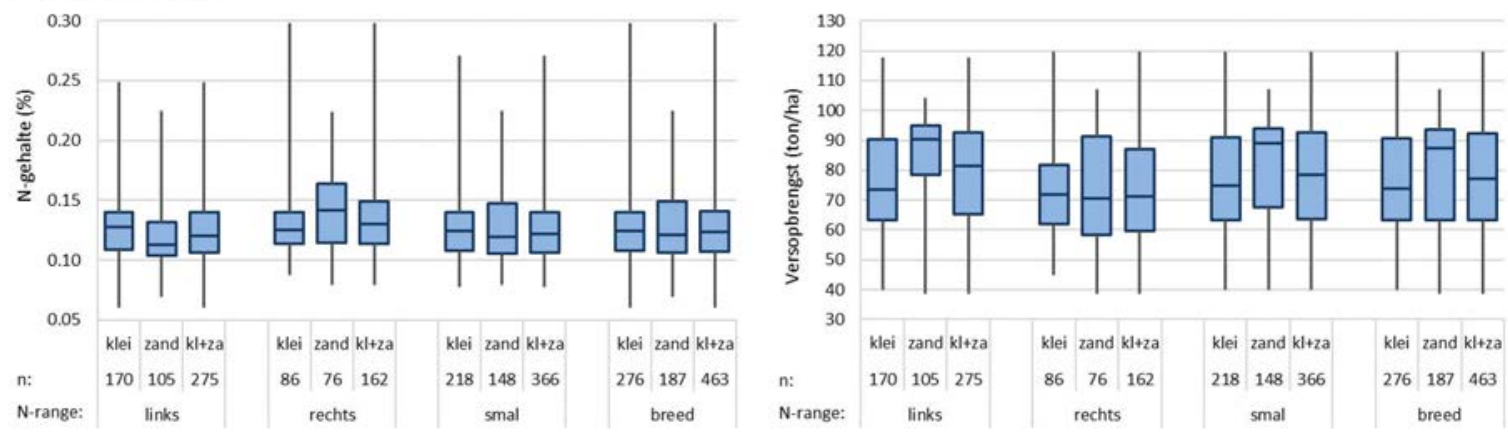


\section{Suikerbieten - P gehalte}
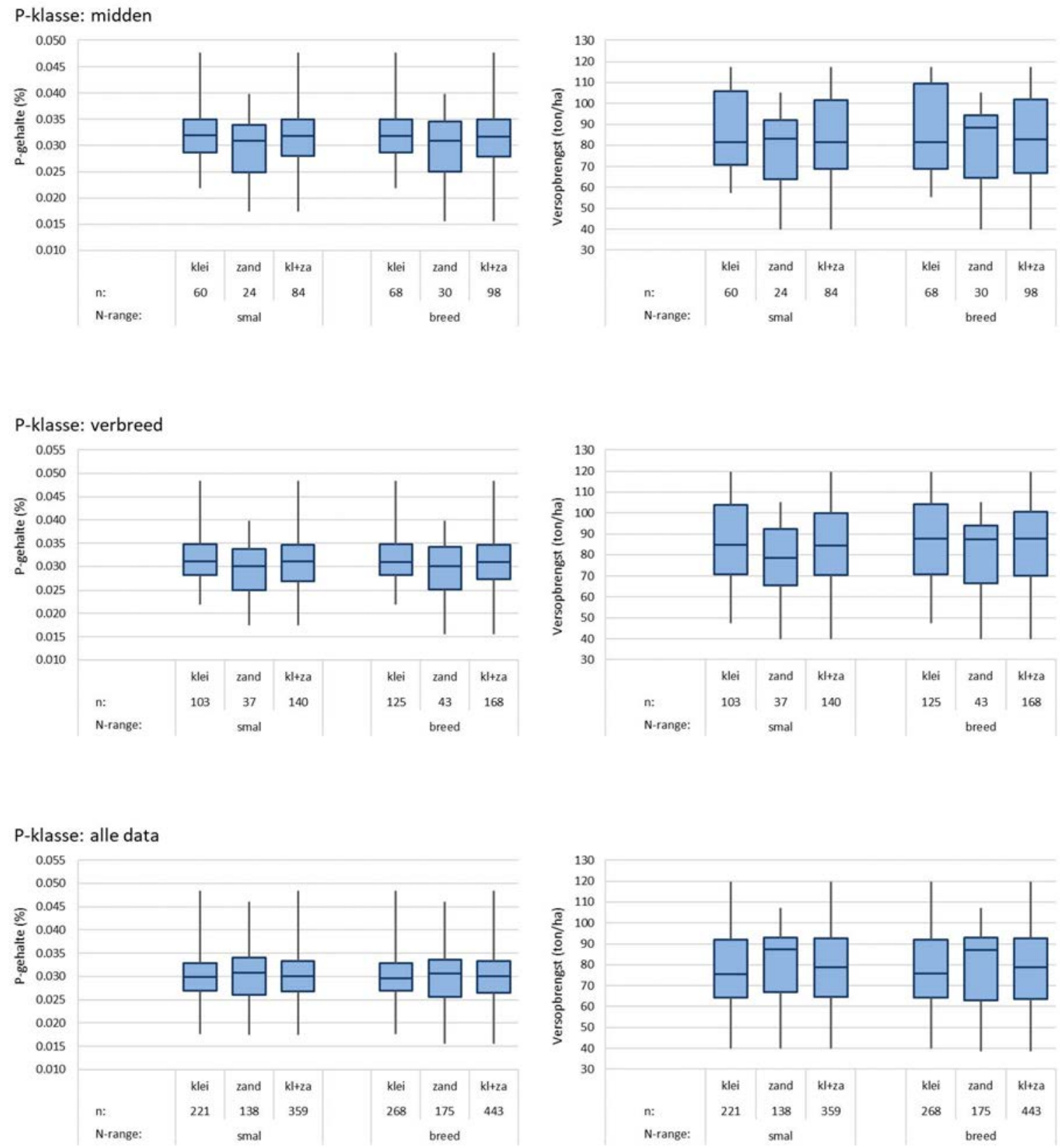


\section{Zaaiuien - $\mathbf{N}$ gehalte}

P-klasse: midden

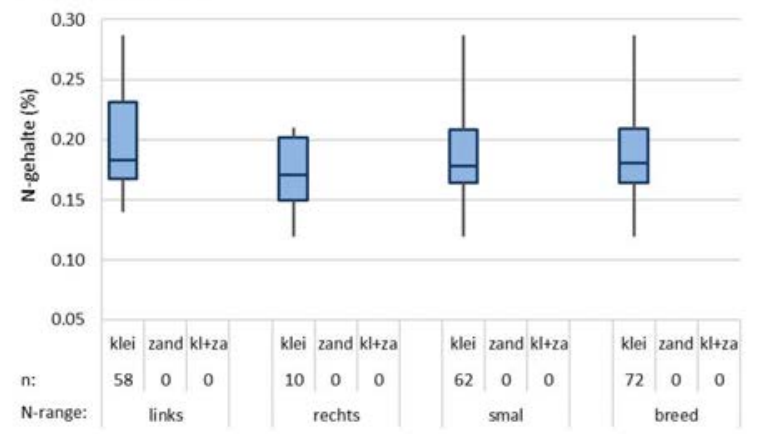

P-klasse: verbreed

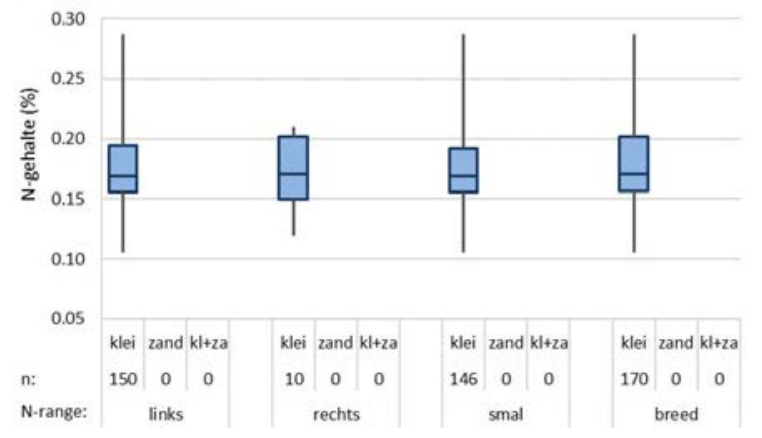

P-klasse: alle data

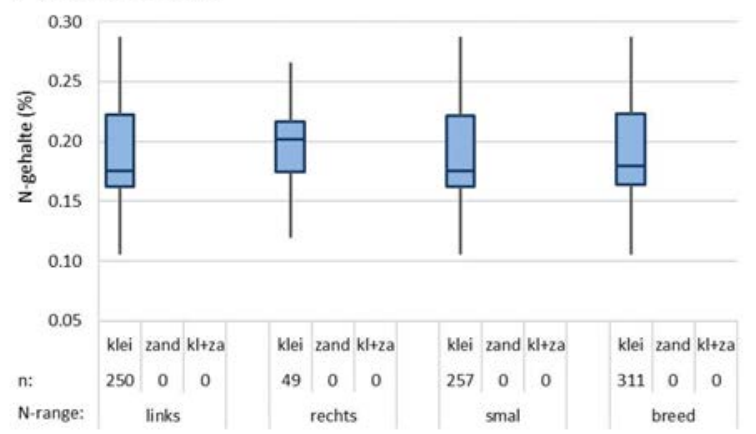

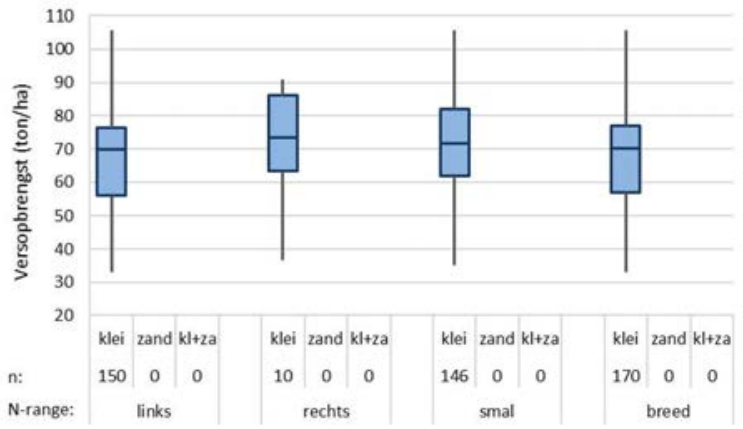

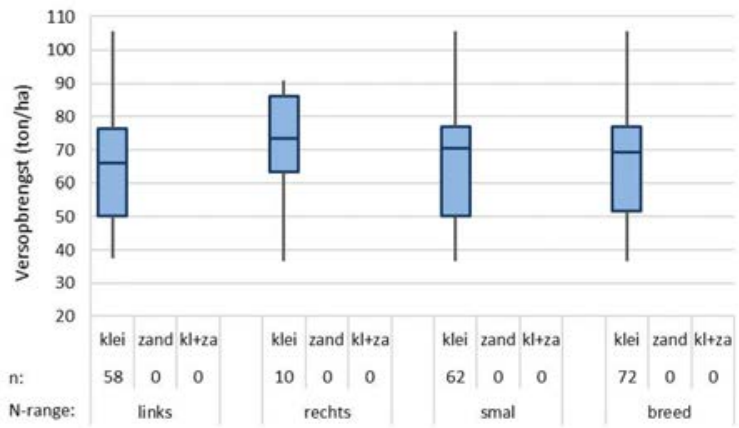

\begin{tabular}{l|l|l|l|l|} 
N-range: & links & rechts & smal & breed \\
\hline
\end{tabular} \begin{tabular}{|l|l|l|l|l|}
$\mathrm{N}$-range: & links & rechts & smal & breed \\
\hline
\end{tabular}

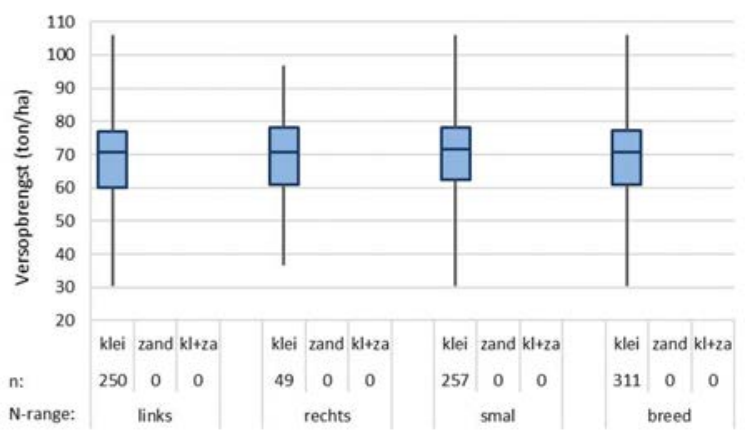




\section{Zaaiuien - P gehalte}

P-klasse: midden

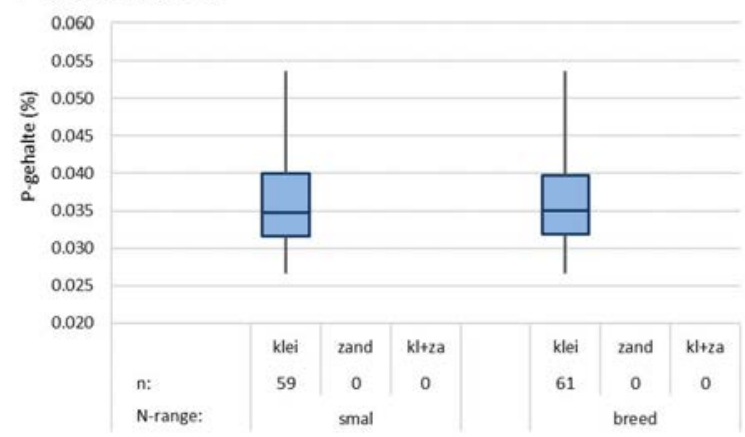

P-klasse: verbreed

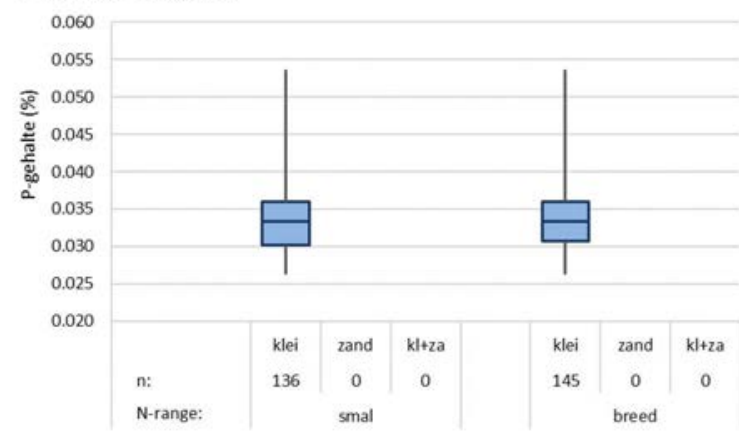

P-klasse: alle data

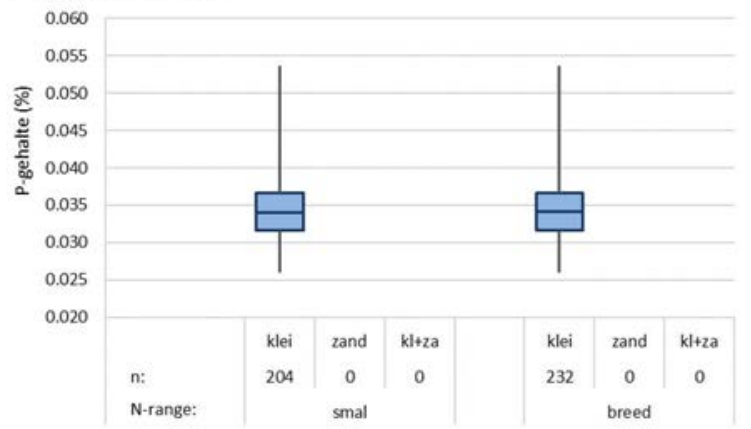

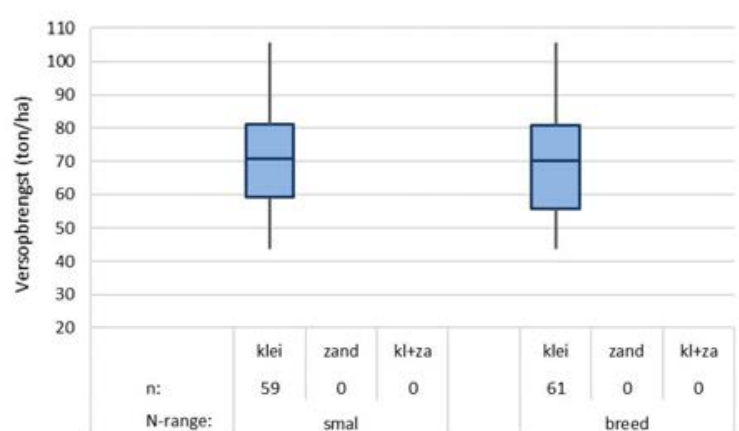
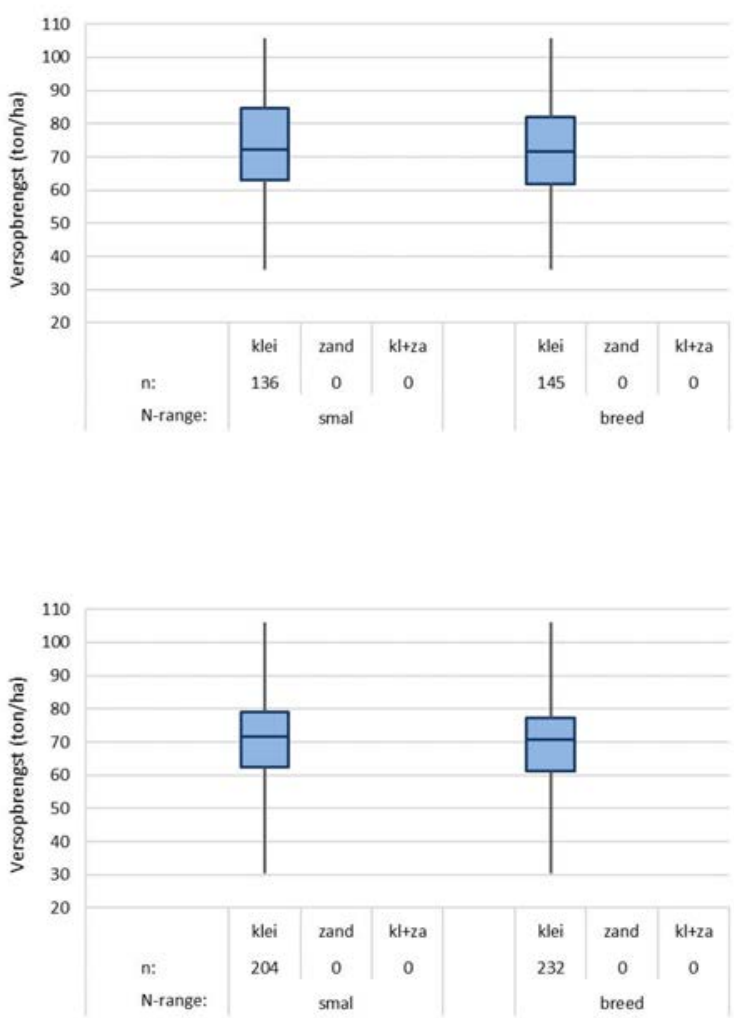


\section{Wintertarwe - N gehalte}
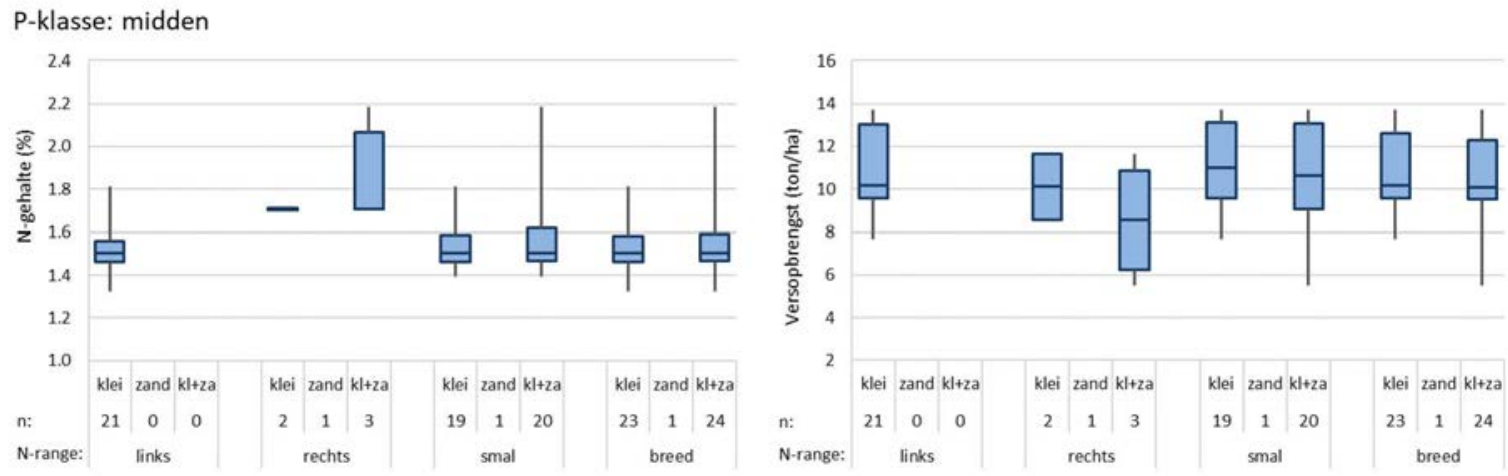

\section{P-klasse: verbreed}
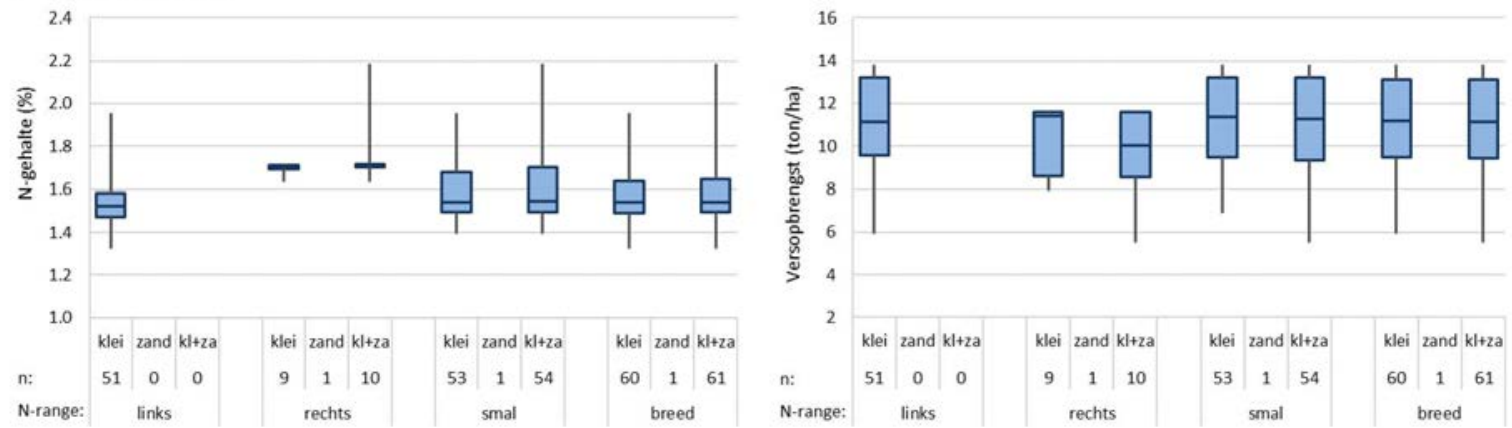

P-klasse: alle data
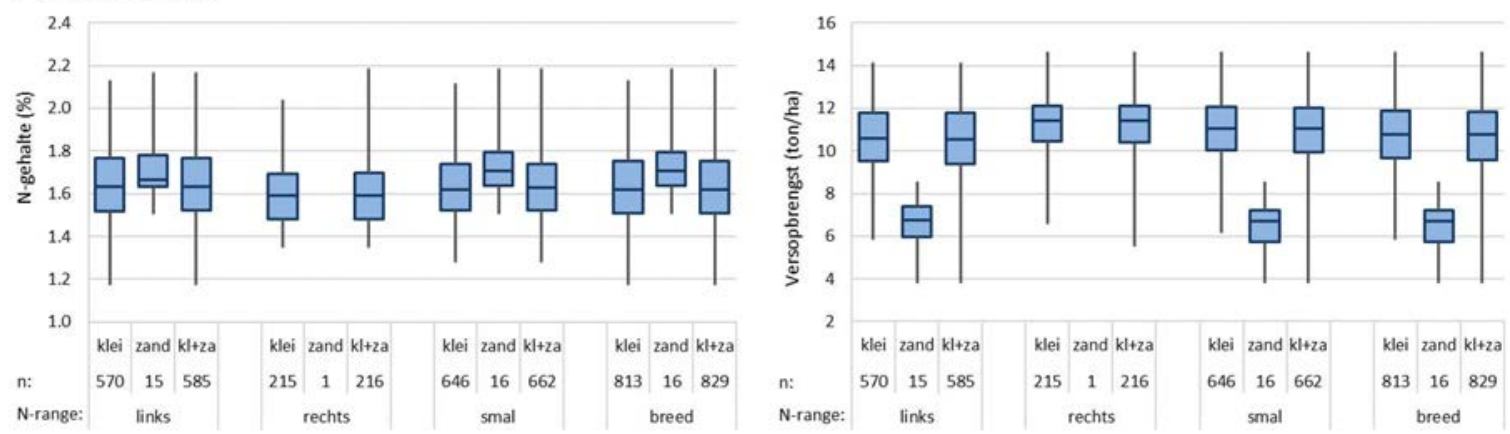
Wintertarwe - P gehalte
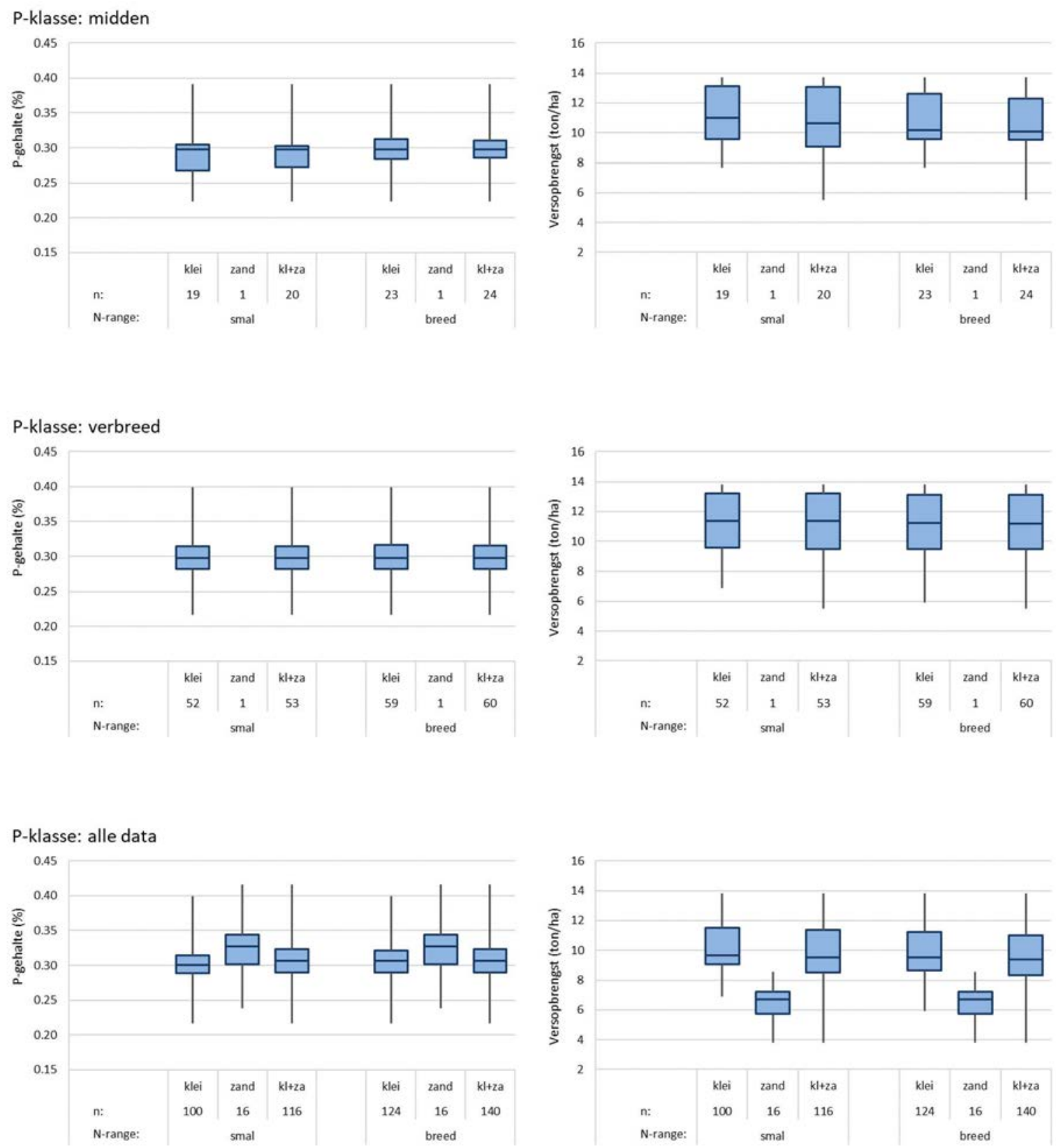


\section{Zomertarwe - $\mathbf{N}$ gehalte}
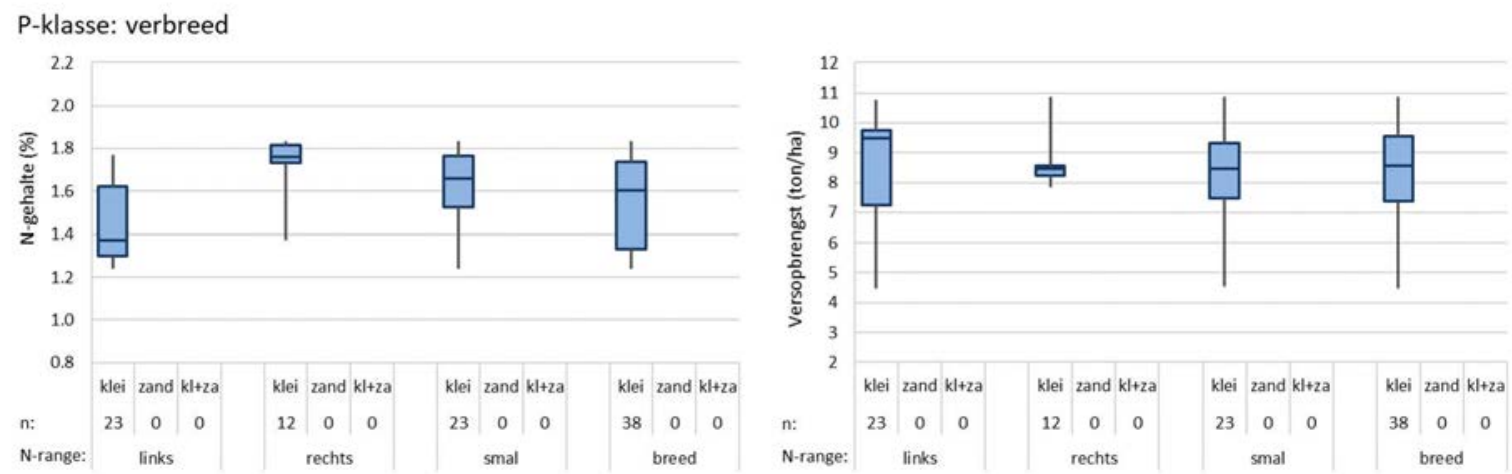

P-klasse: alle data
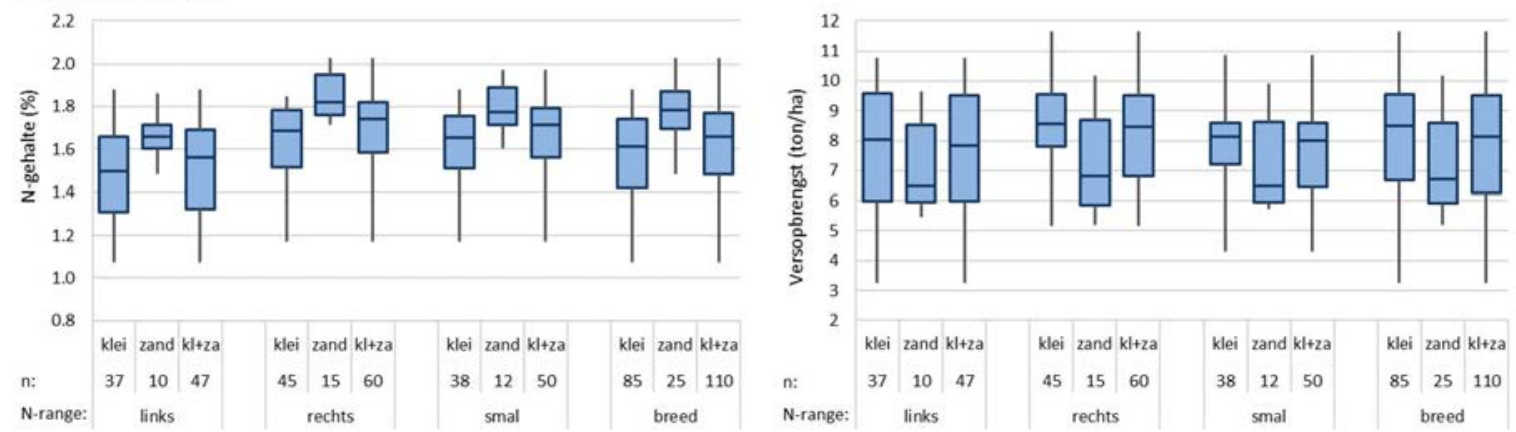

\section{Zomertarwe - P gehalte}
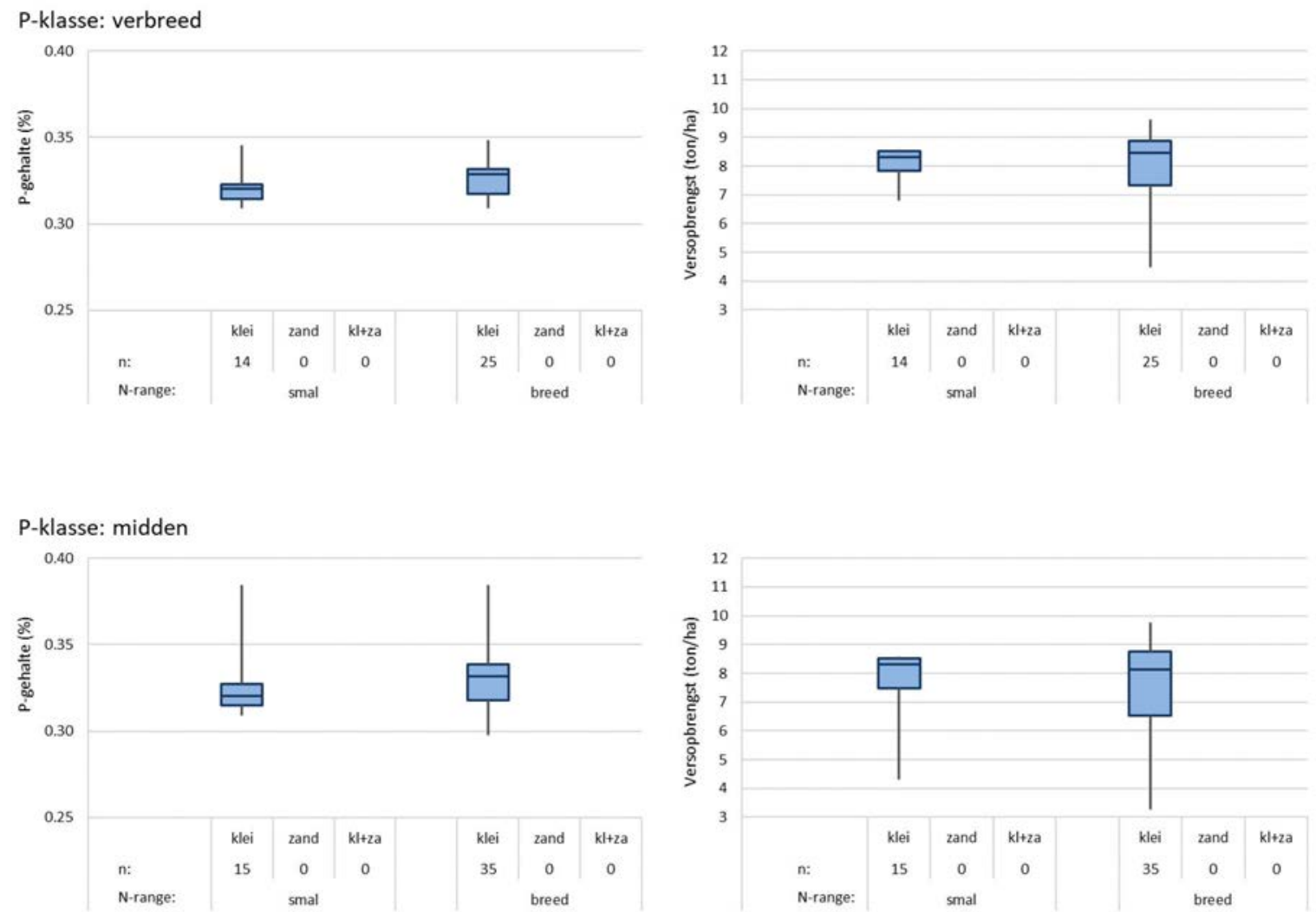
Wintergerst - N gehalte (geen data over P-gehalte)
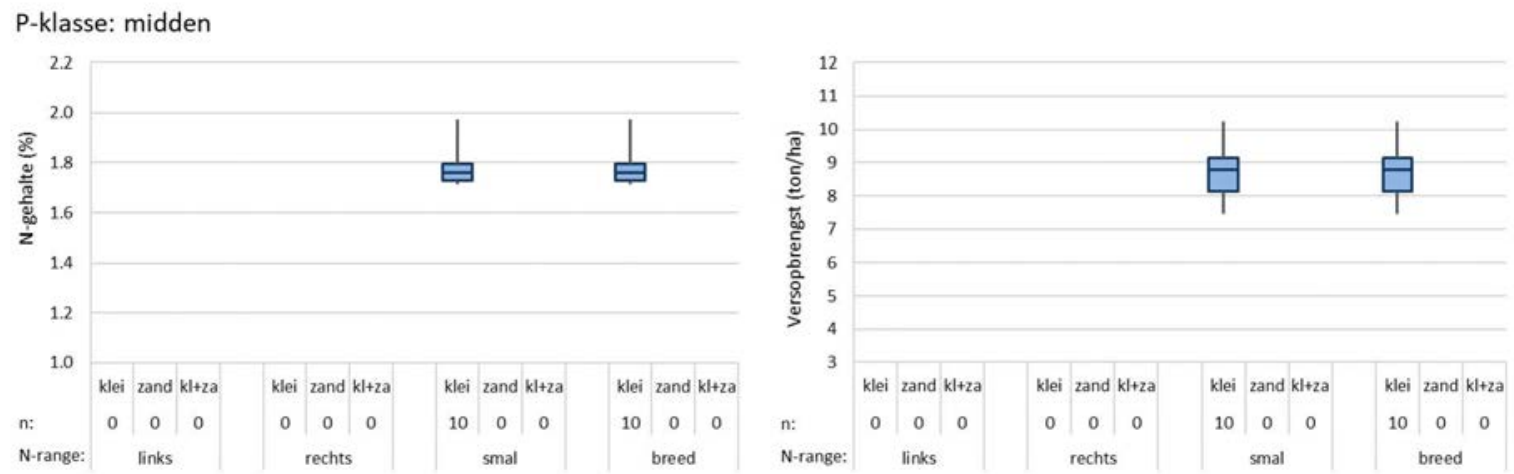

P-klasse: verbreed
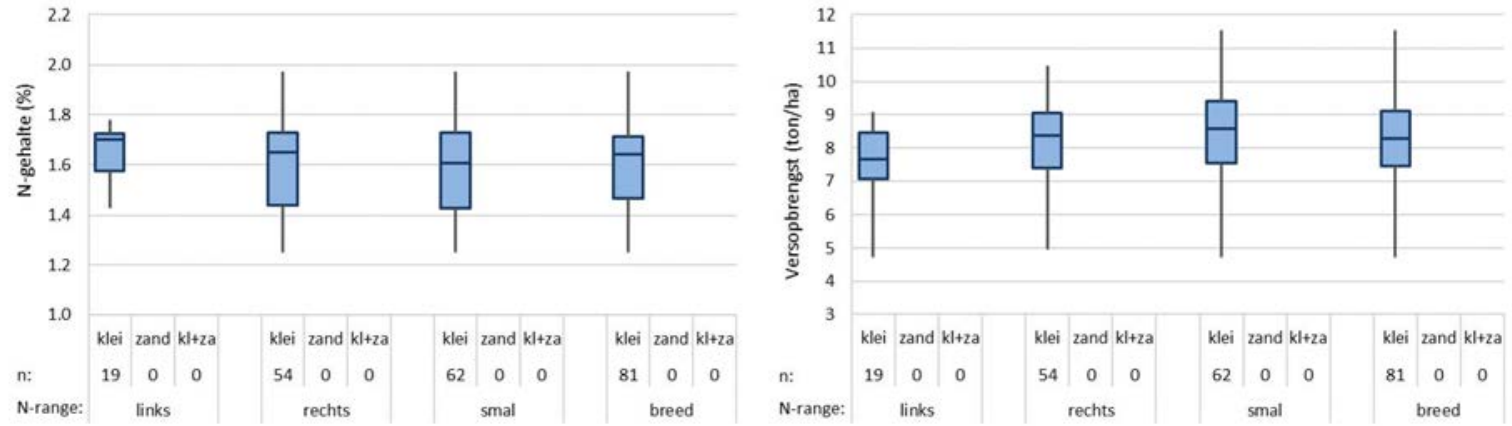

P-klasse: alle data
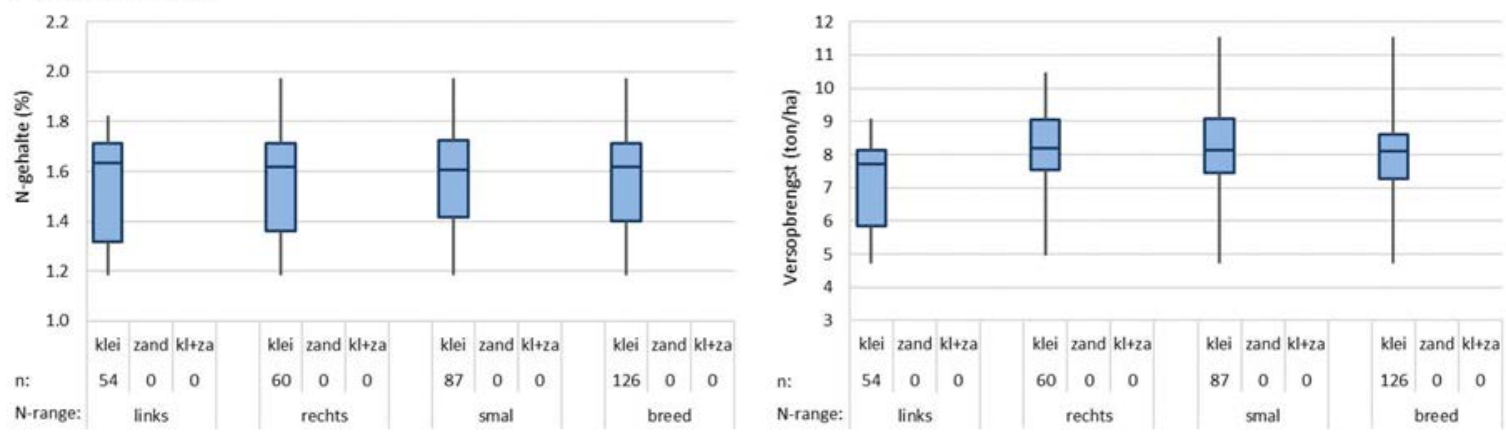


\section{Zomergerst - $\mathbf{N}$ gehalte}

P-klasse: midden

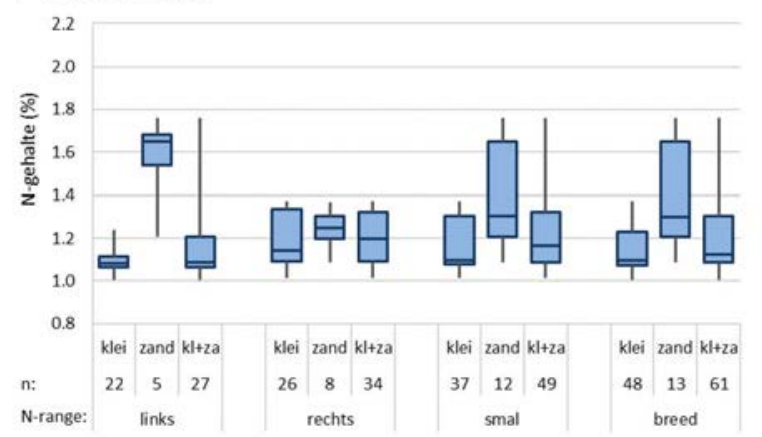

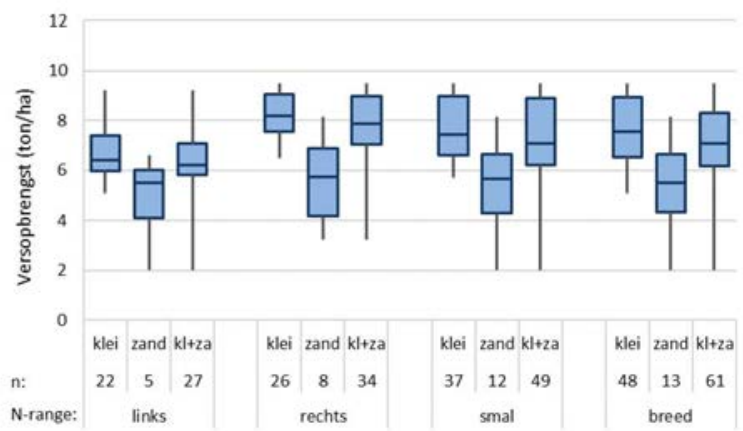

P-klasse: verbreed
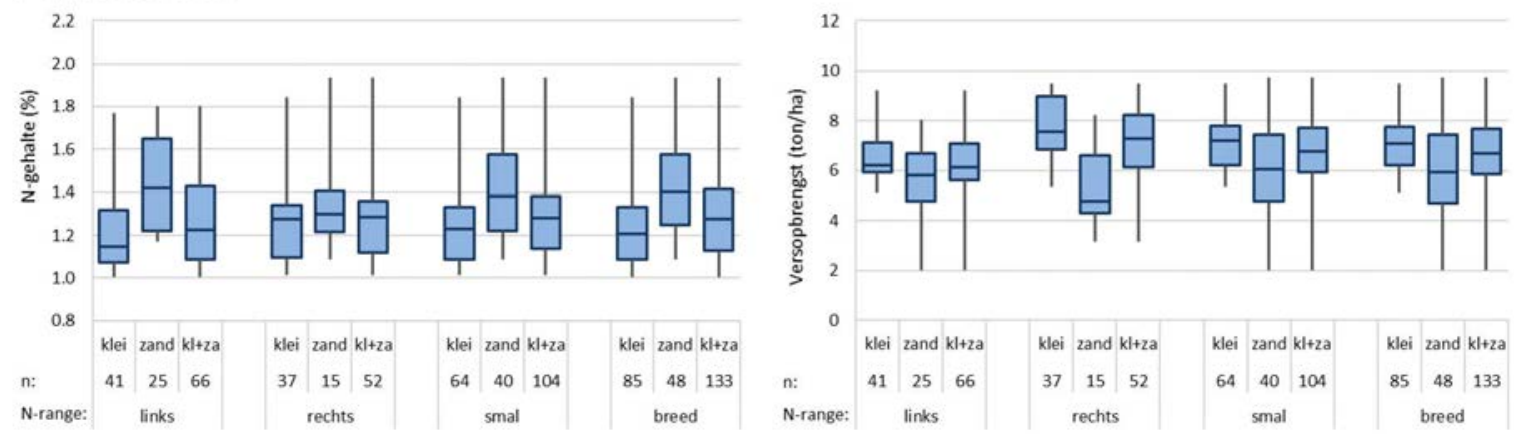

P-klasse: alle data
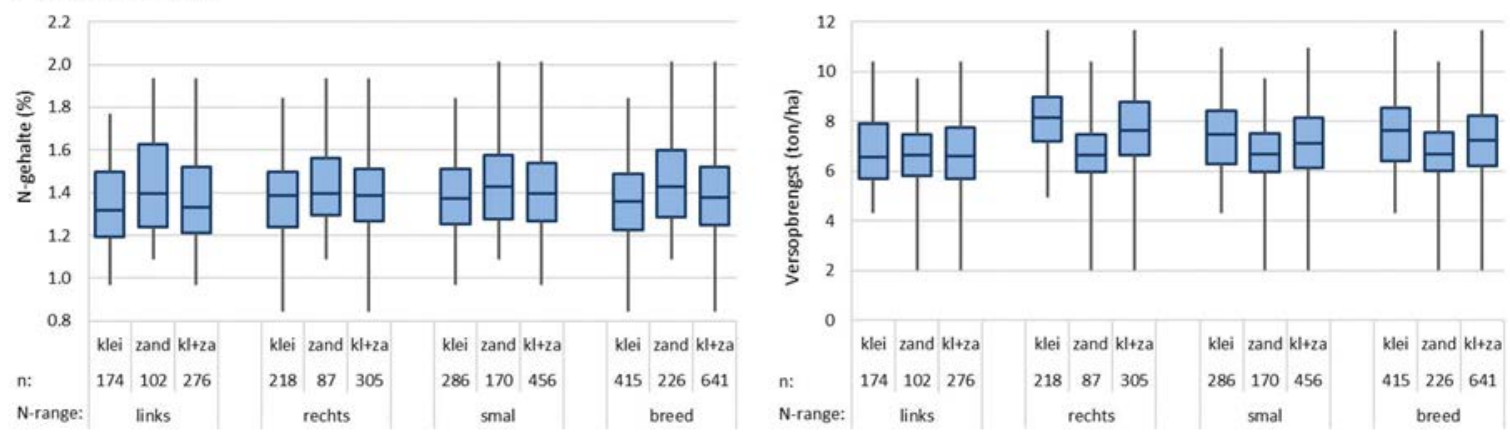


\section{Zomergerst - P gehalte}
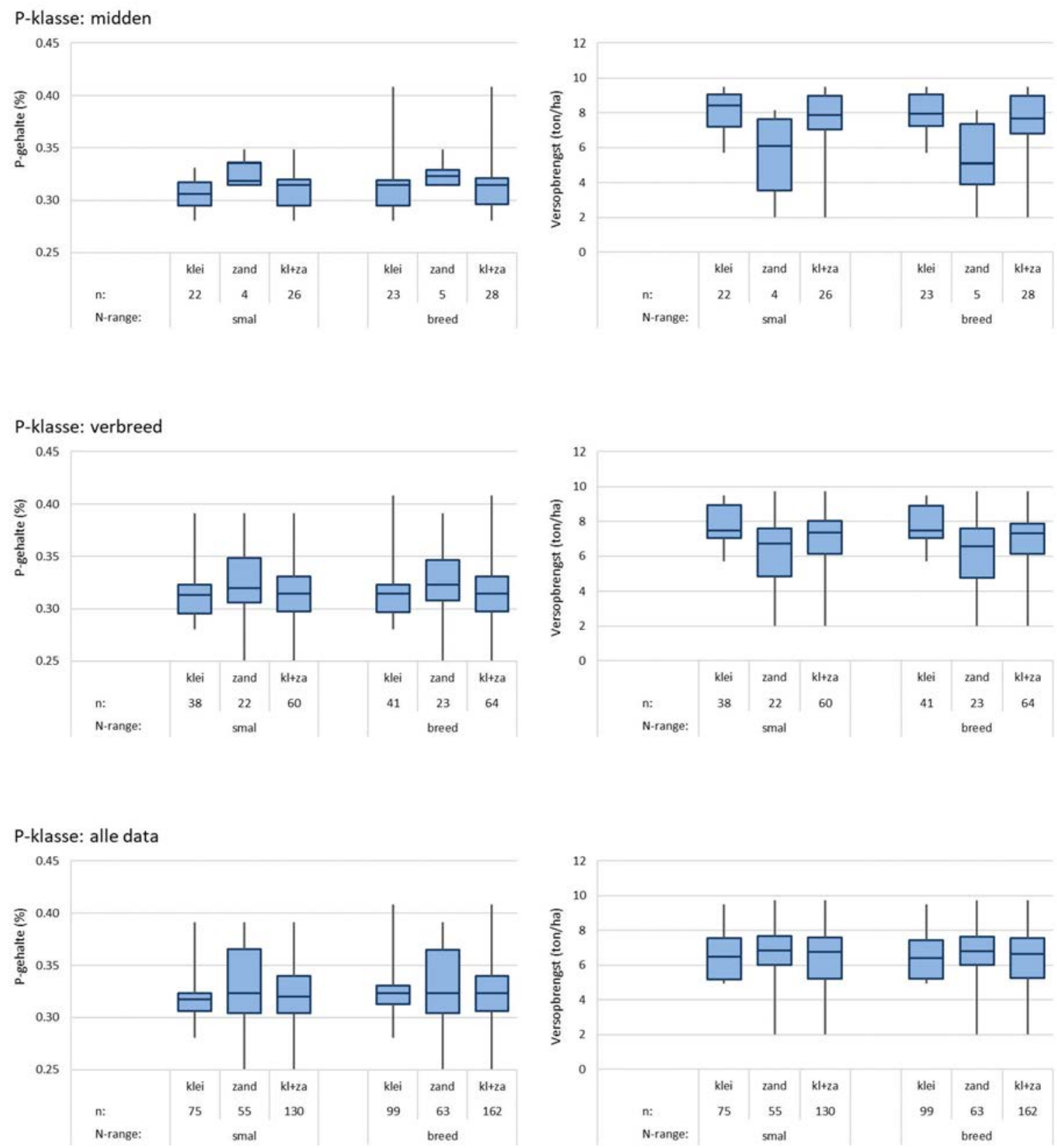


\section{Was- en winterpeen - $\mathbf{N}$ gehalte}

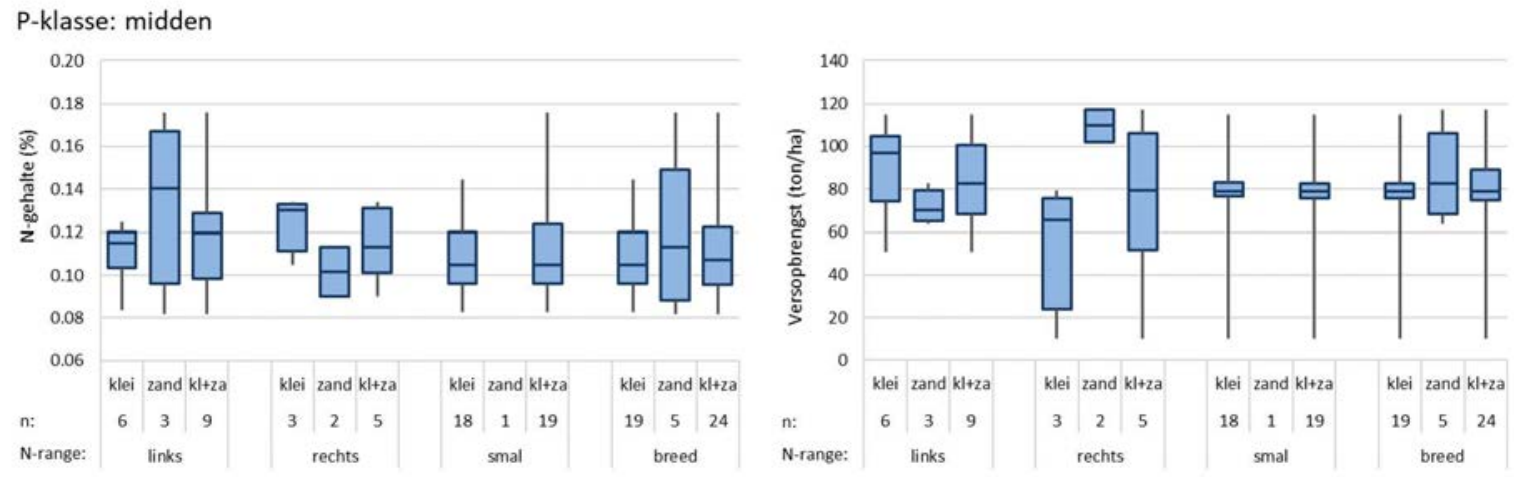

P-klasse: verbreed

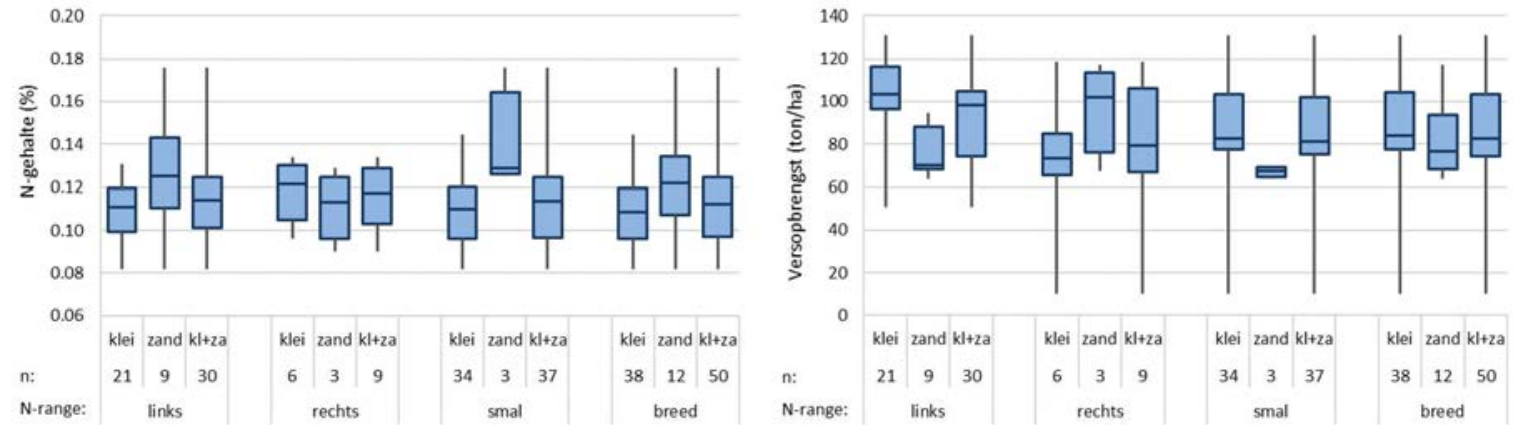

P-klasse: alle data
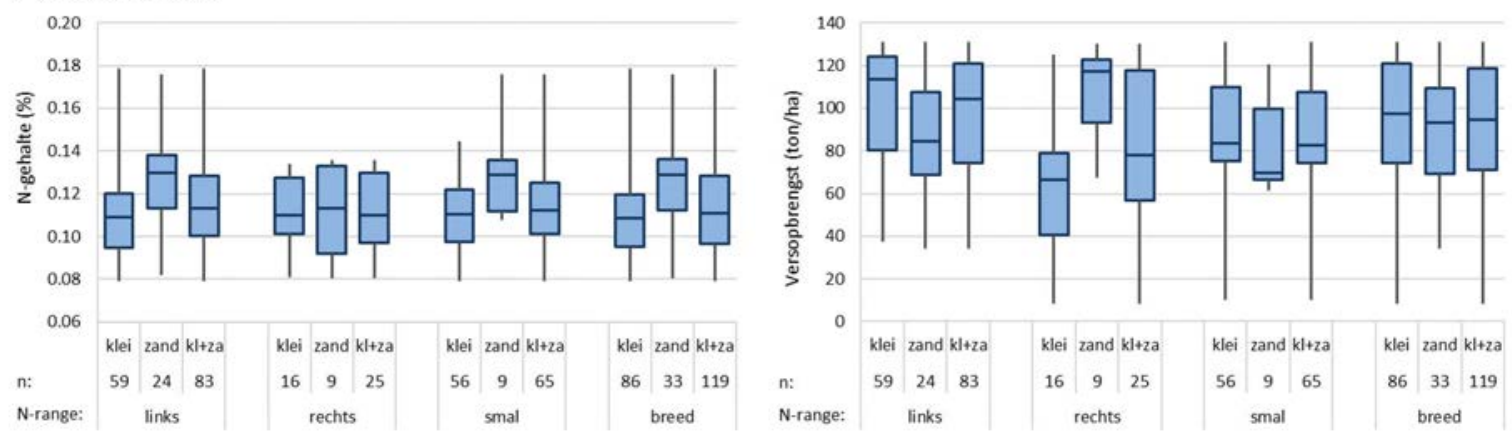


\section{Was- en winterpeen - P gehalte}
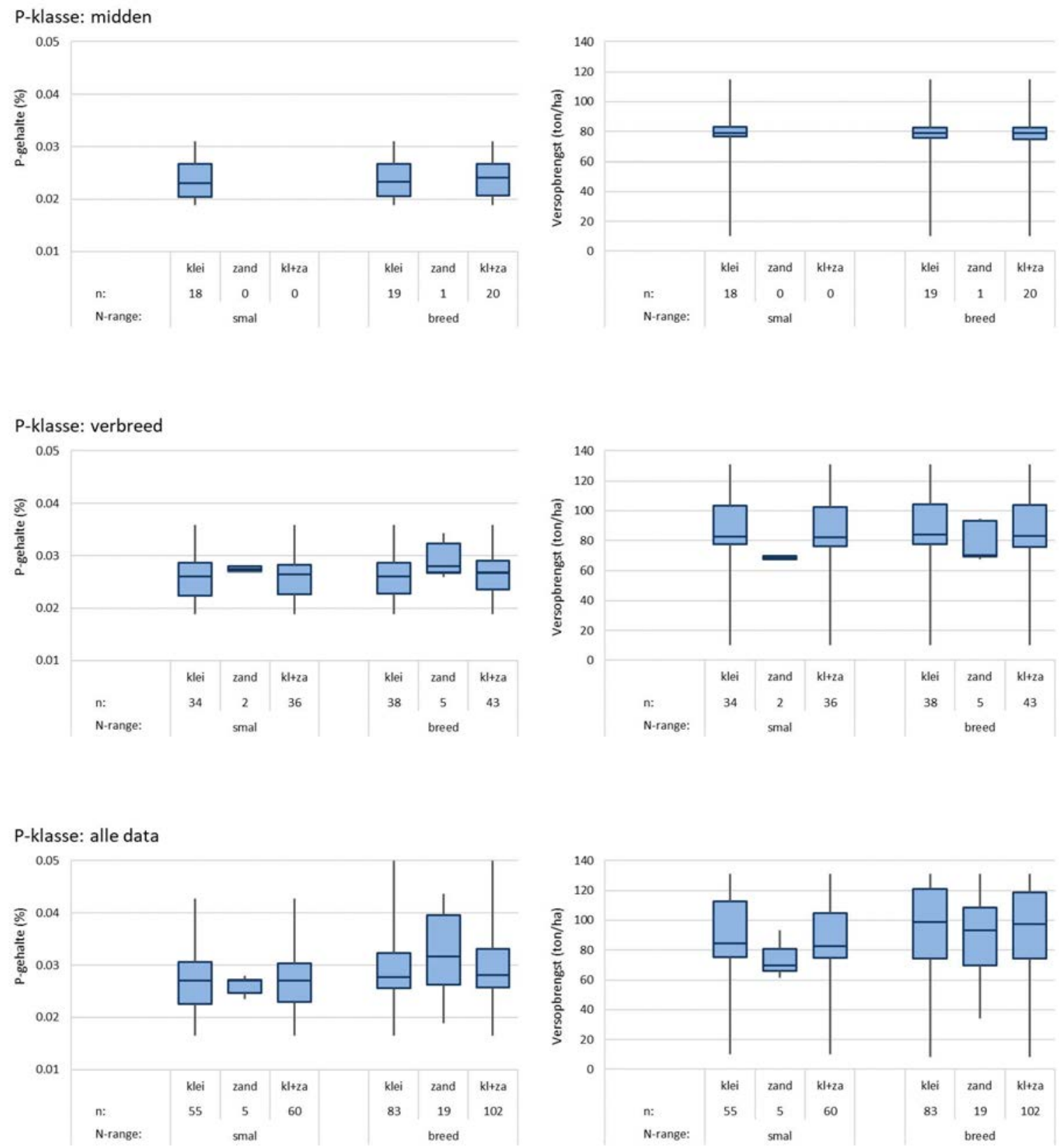


\section{Snijmais - N gehalte}

P-klasse: midden

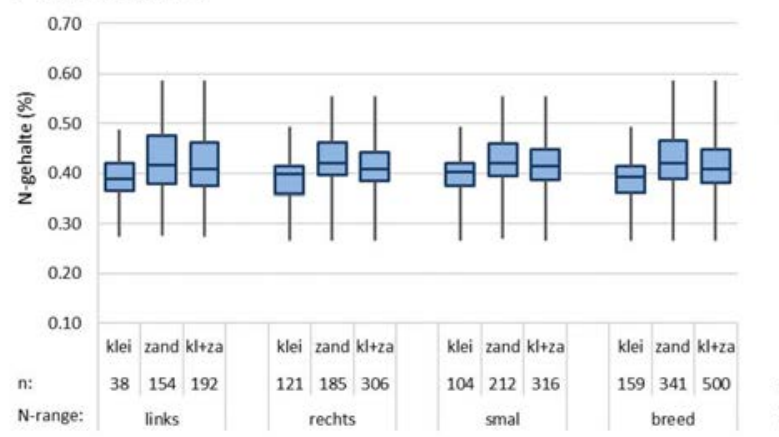

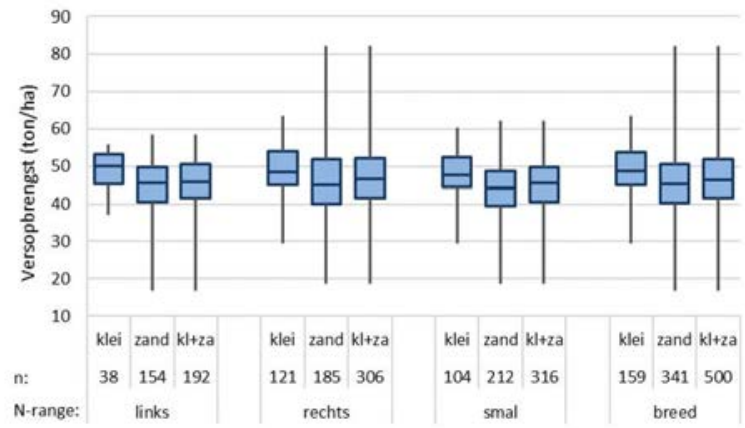

P-klasse: verbreed
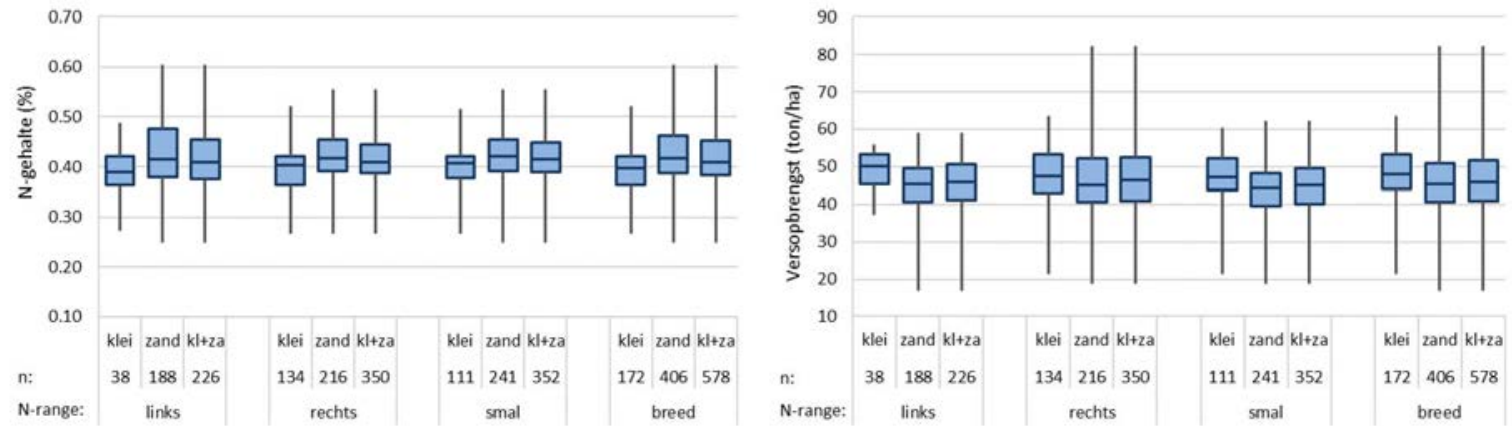

P-klasse: alle data
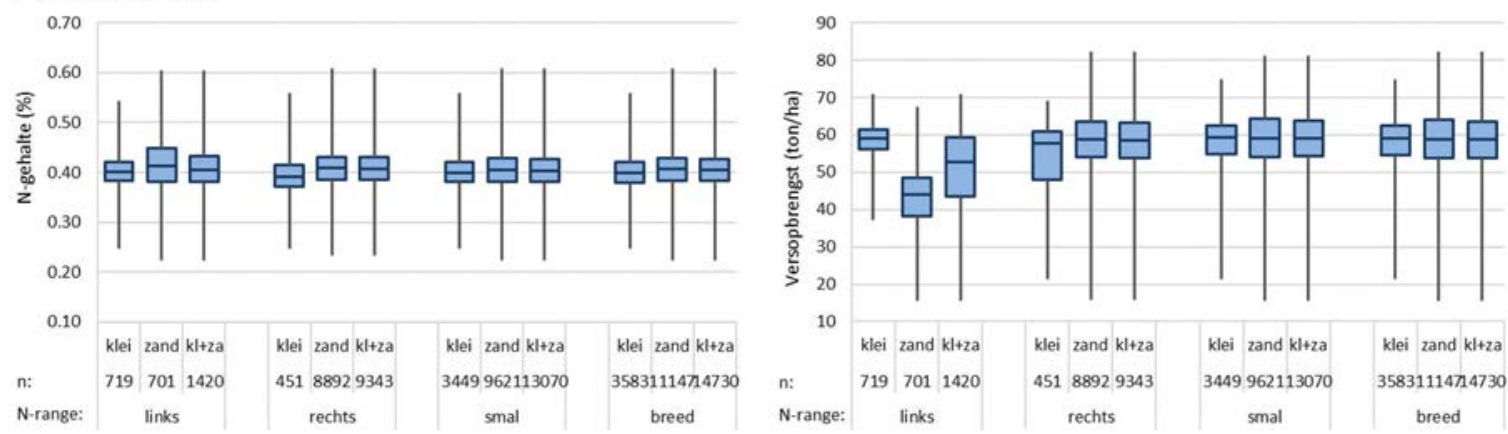


\section{Snijmais - P gehalte}
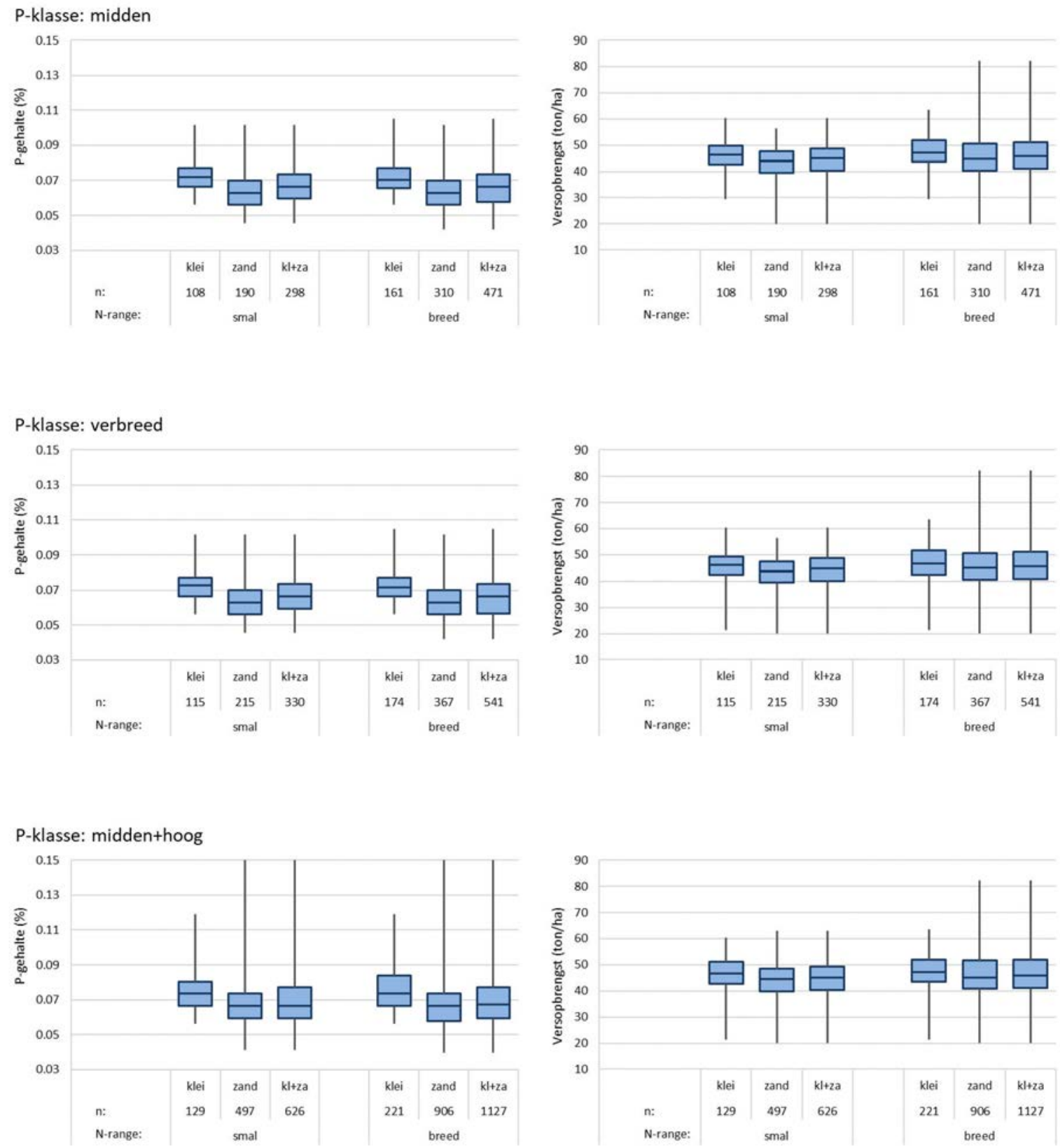


\section{Korrelmais - $\mathbf{N}$ gehalte}

P-klasse: alle data

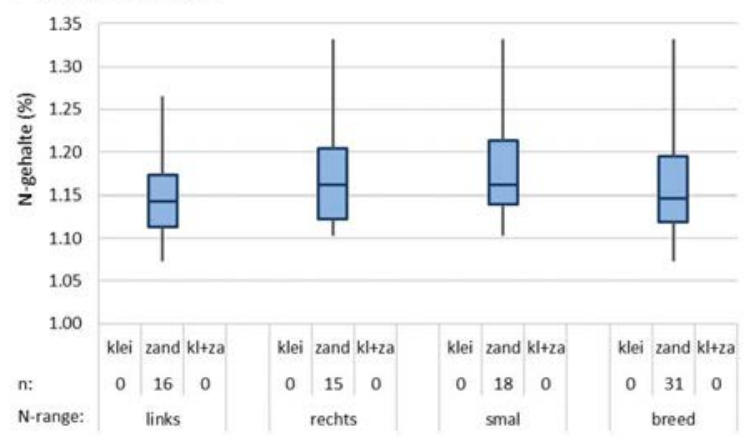

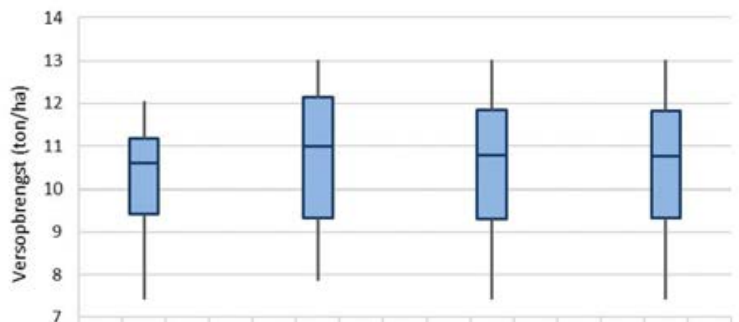

klei zand $\mathrm{kl}+2 \mathrm{a} \quad k$ klei zand $\mathrm{kl}+z \mathrm{a}$ klei zand $\mathrm{kl}+2 \mathrm{a}$ klei zand $\mathrm{kl}+2 \mathrm{a}$

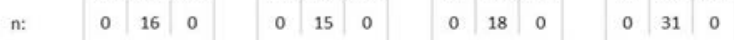

\section{Korrelmais - P gehalte}
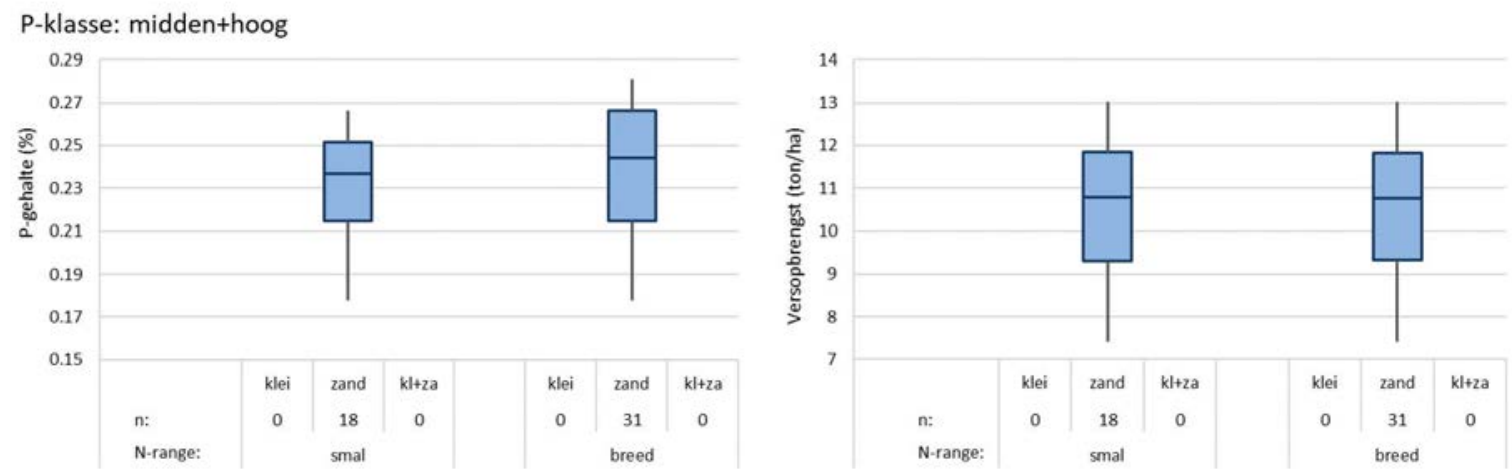

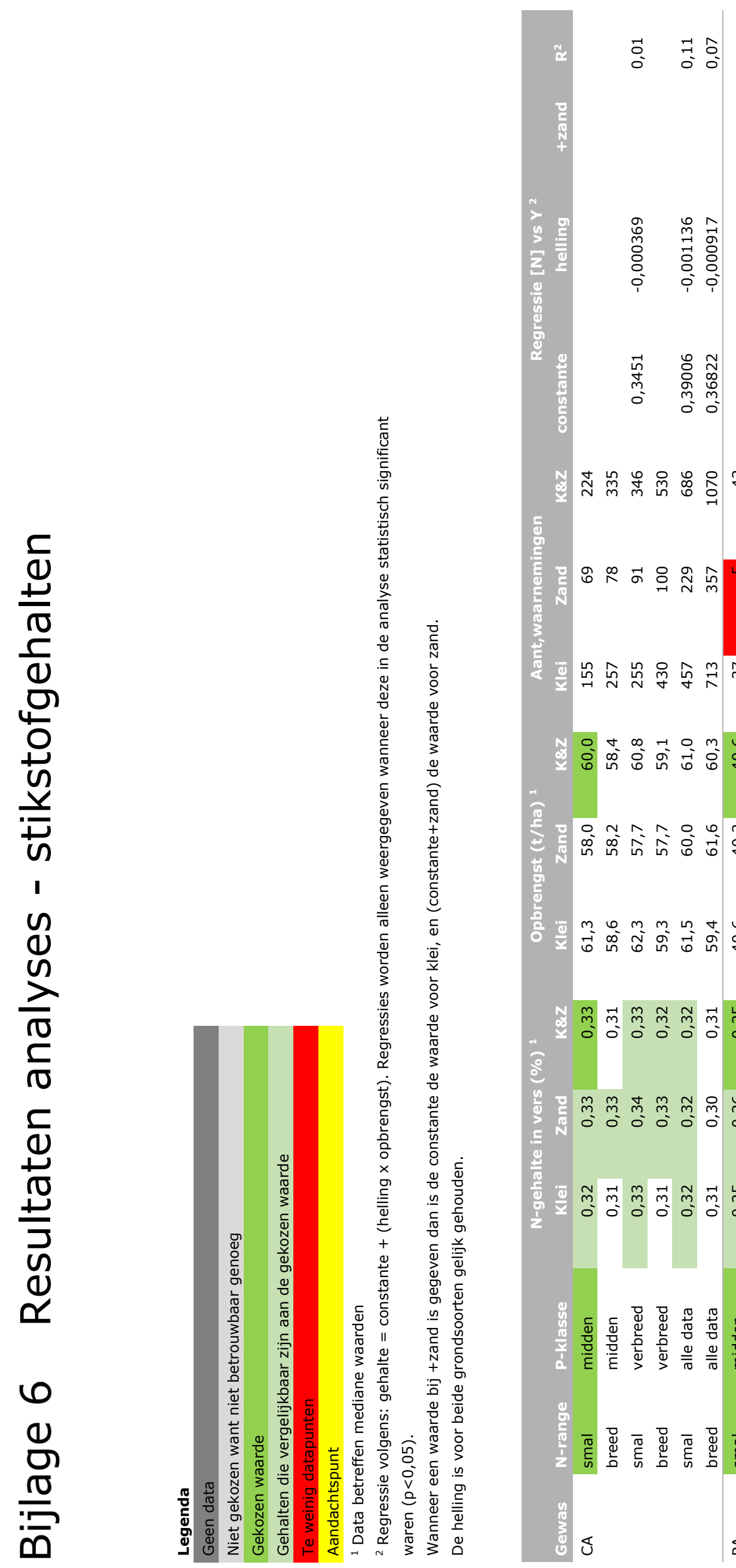

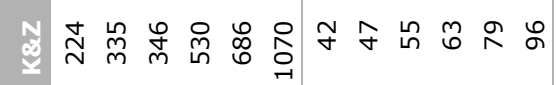

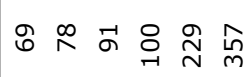

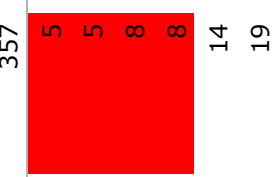

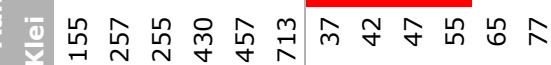

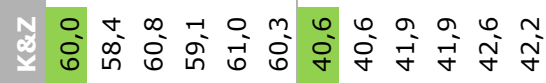

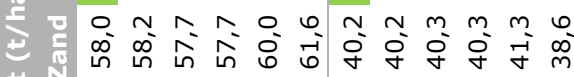

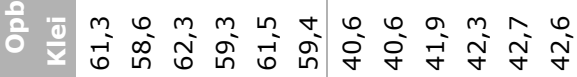

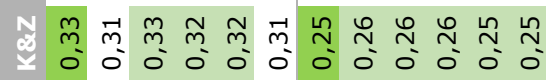

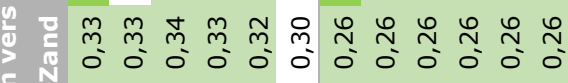

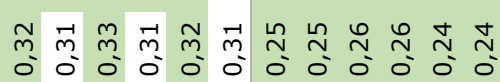

$z$

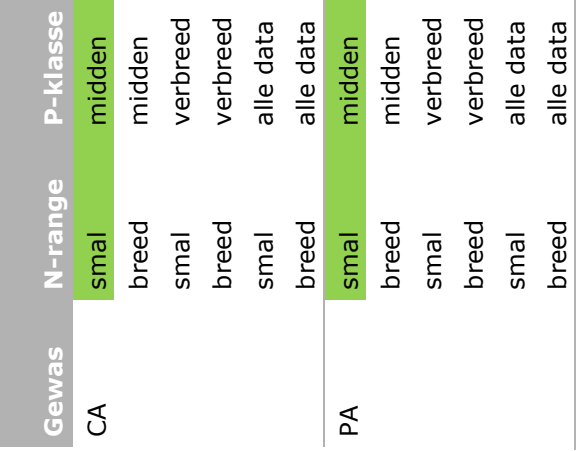




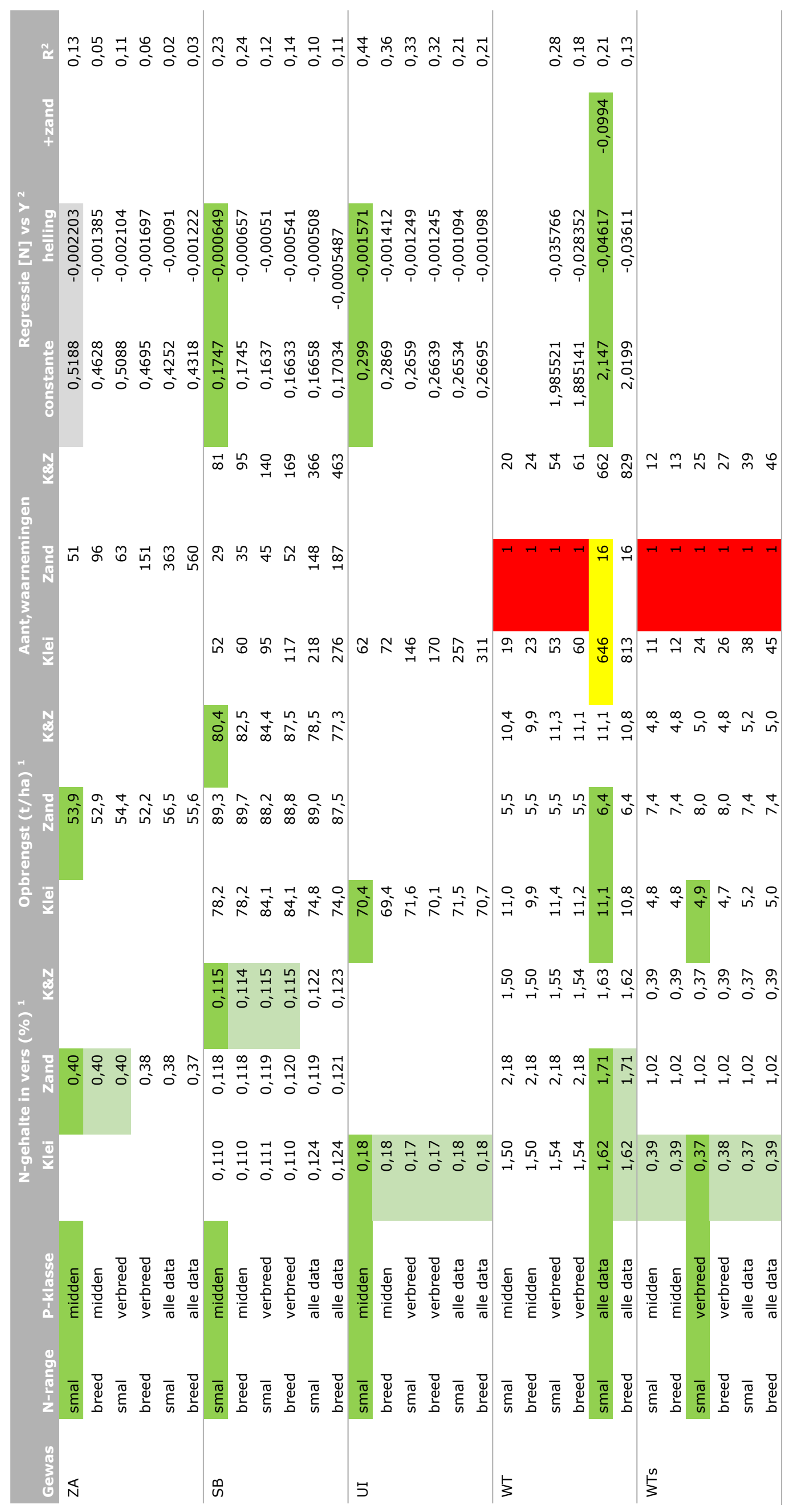




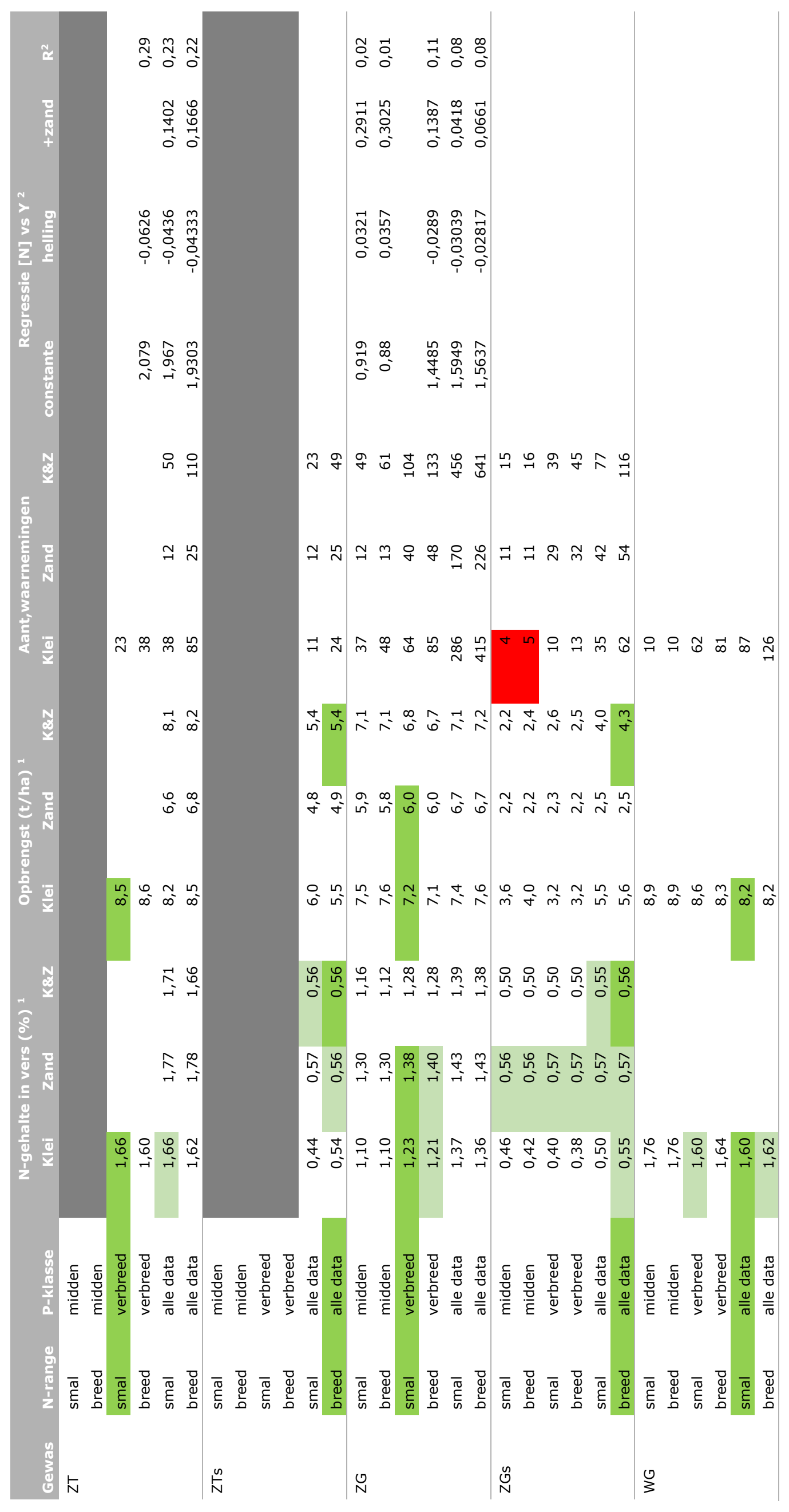




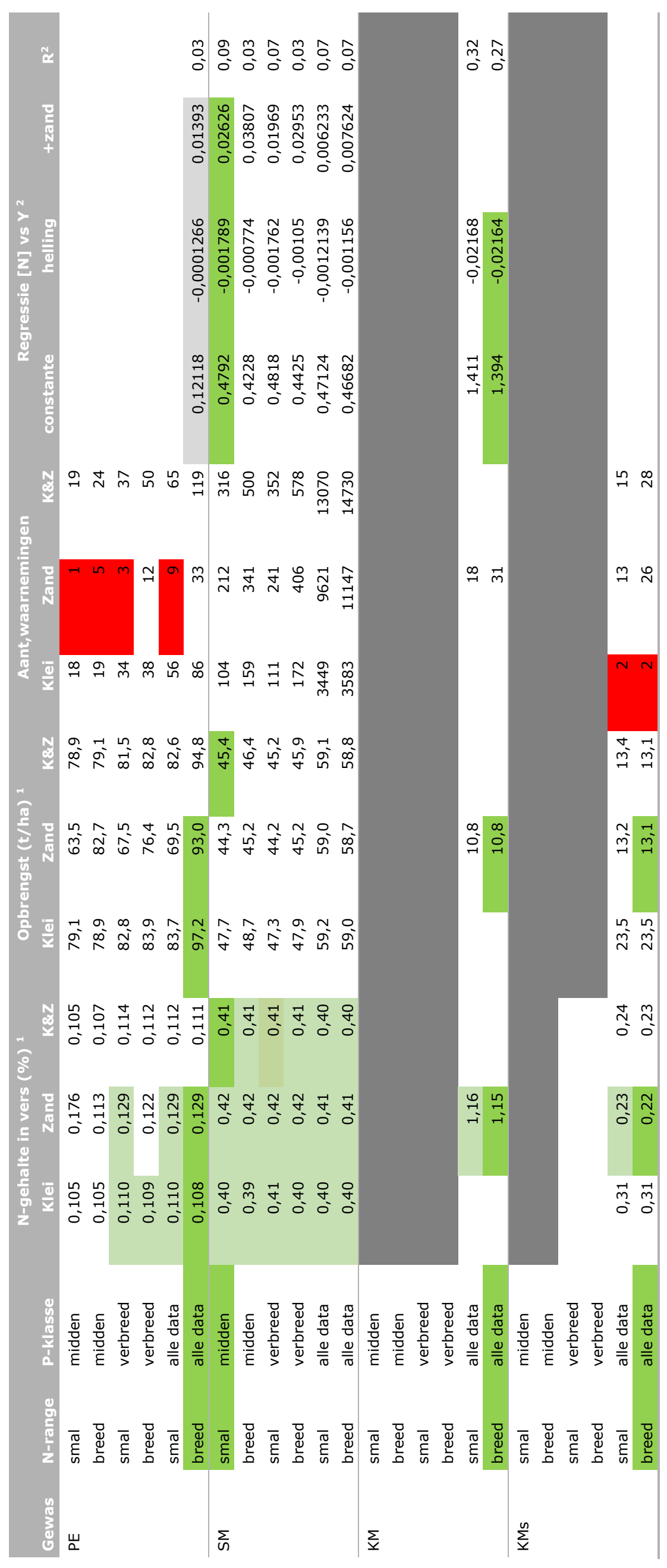




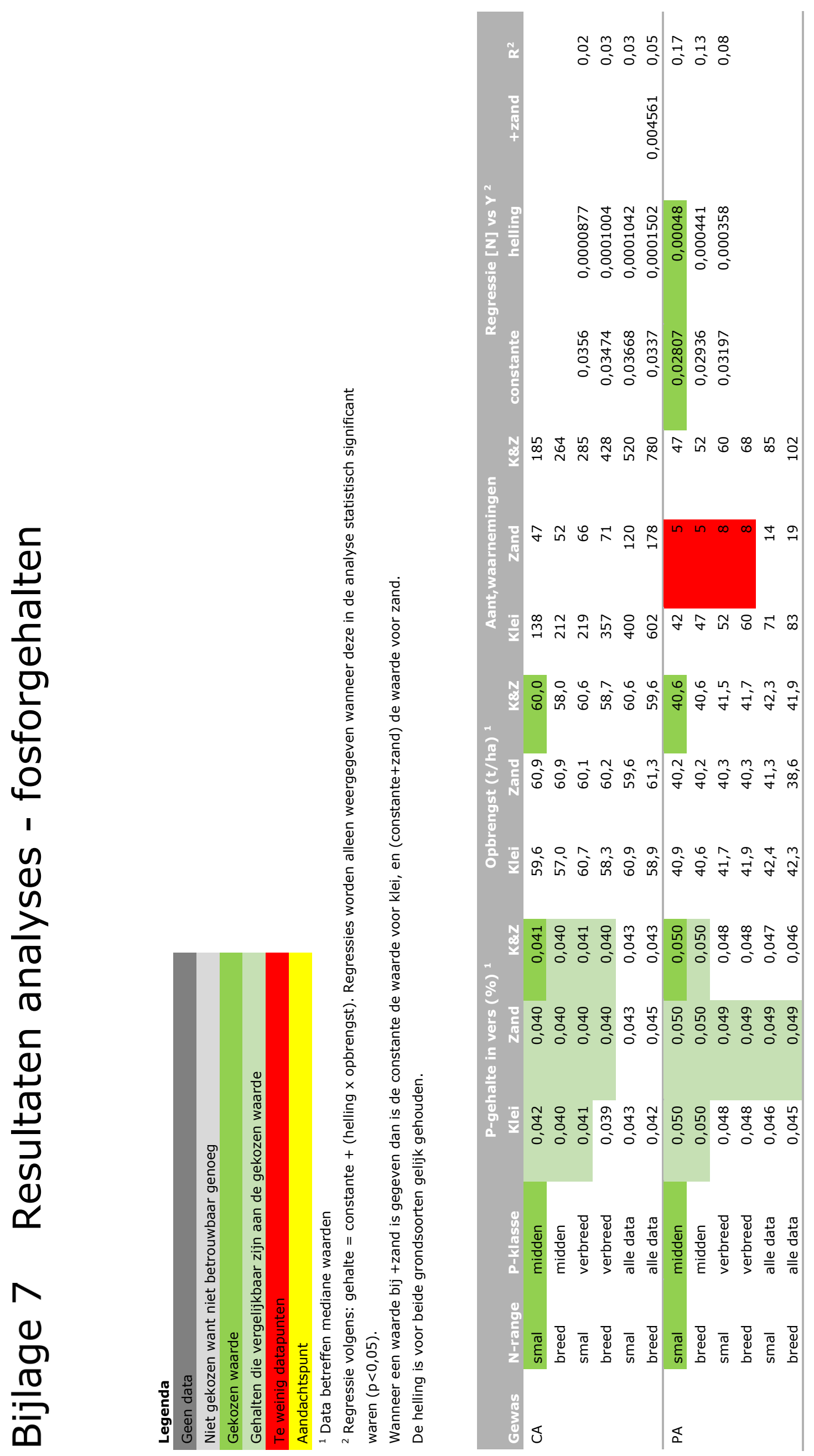




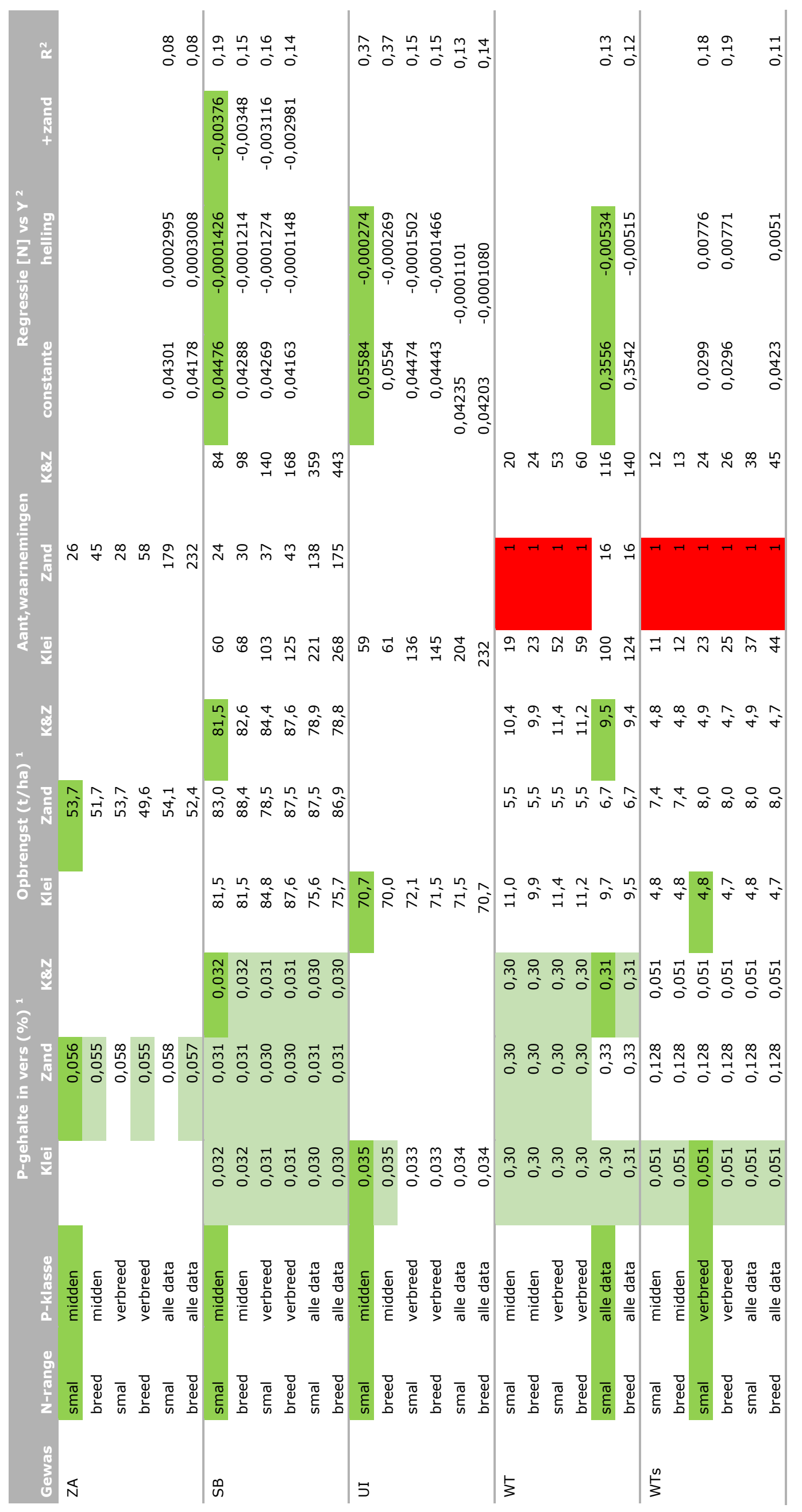




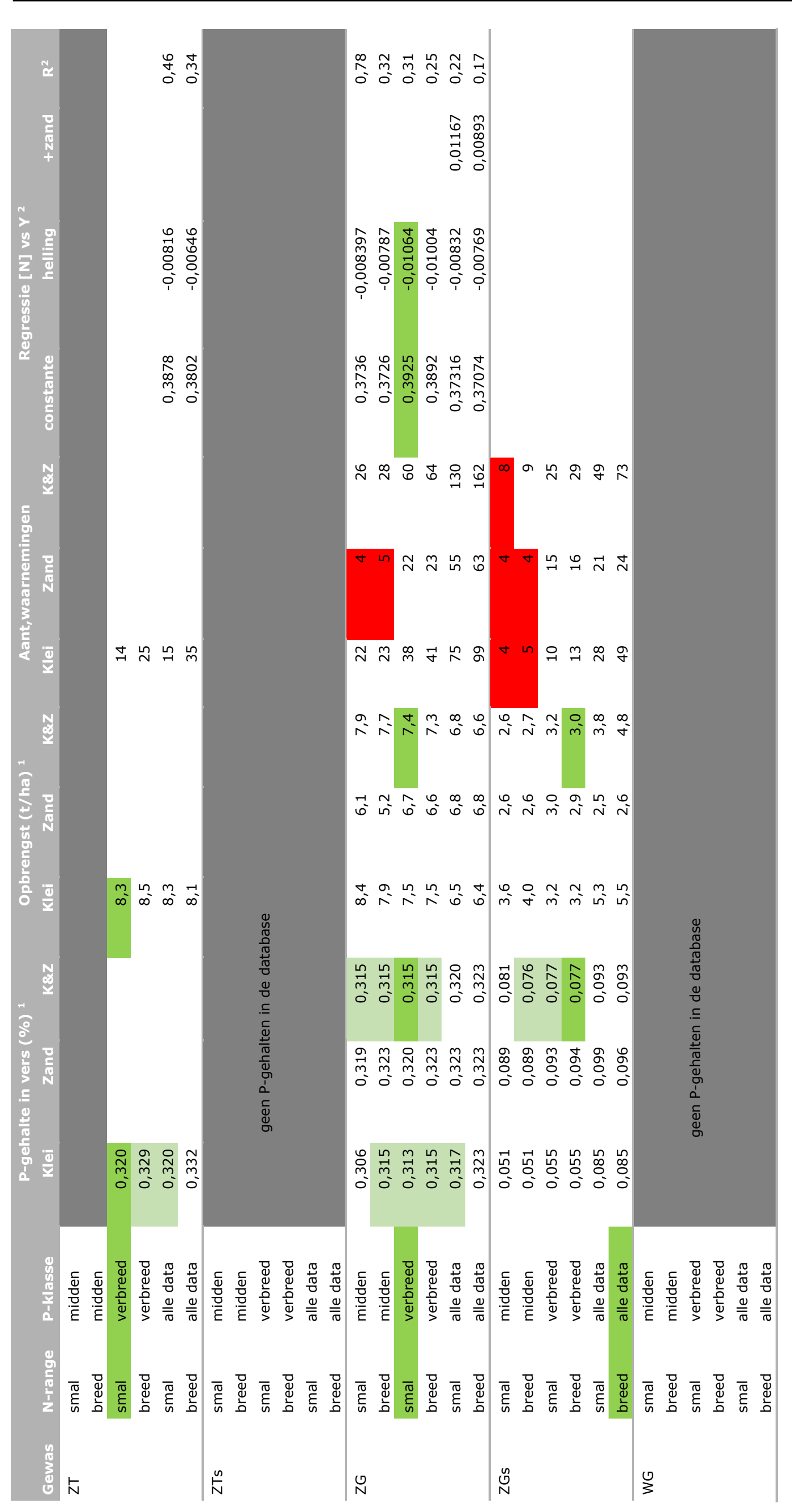




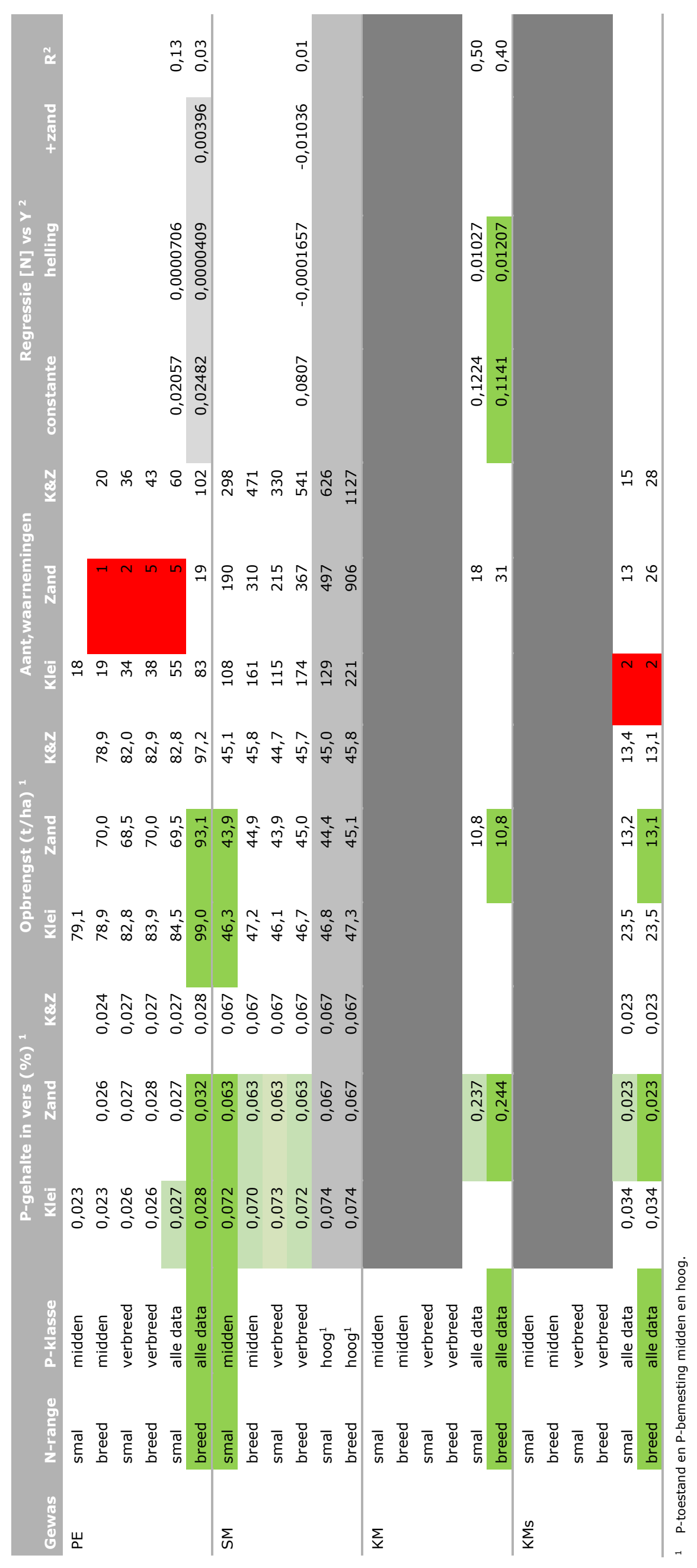




\section{Bijlage 8 Figuren van geselecteerde data}

Figuren geven de data weer die horen bij de selectie voor N- en P-gehalte zoals aangegeven in Bijlagen 6 en 7 .

\section{Consumptieaardappelen}

$\mathrm{N}$-range smal, $\mathrm{P}$-klasse midden
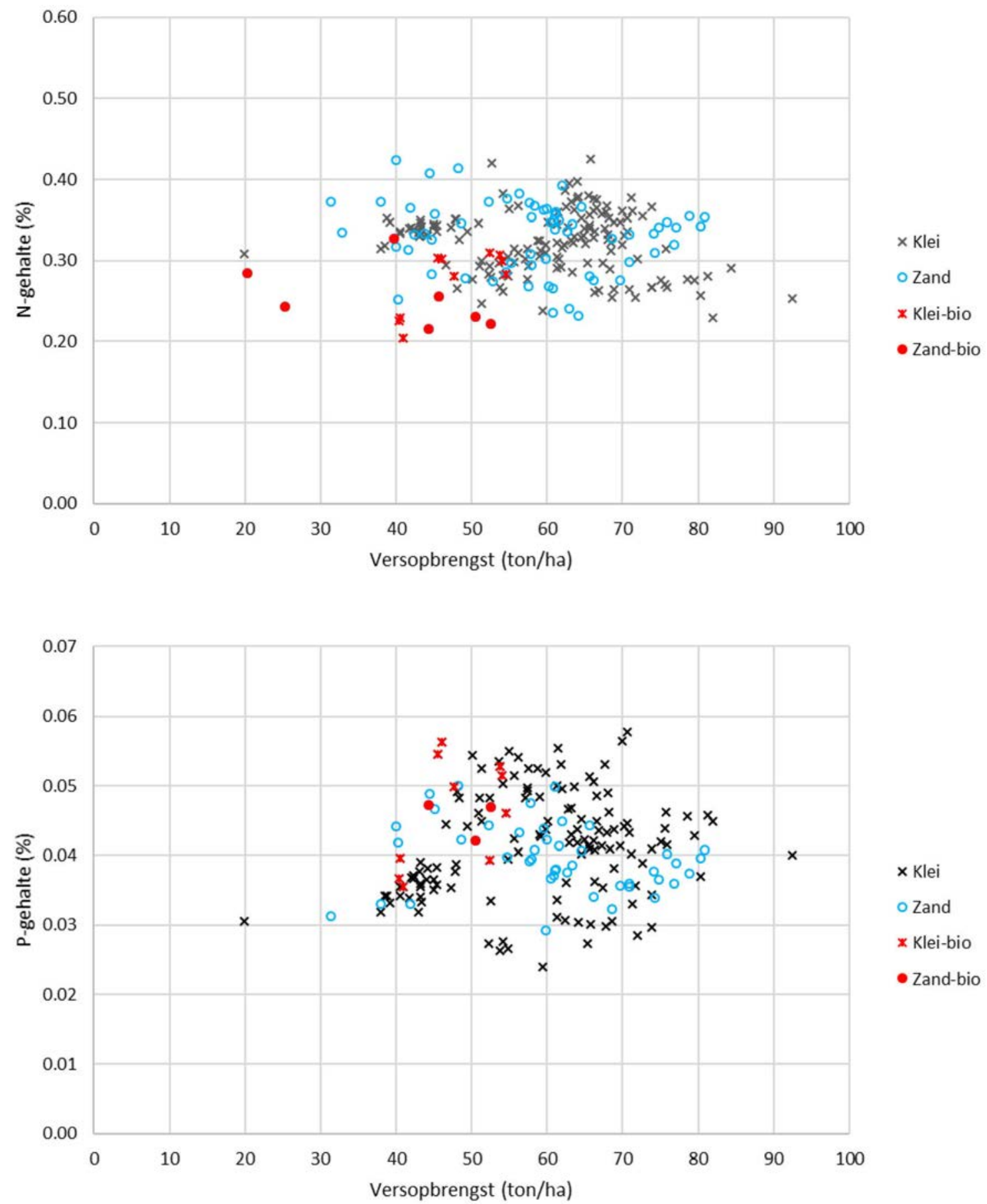


\section{Pootaardappelen}

$\mathrm{N}$-range smal, P-klasse midden
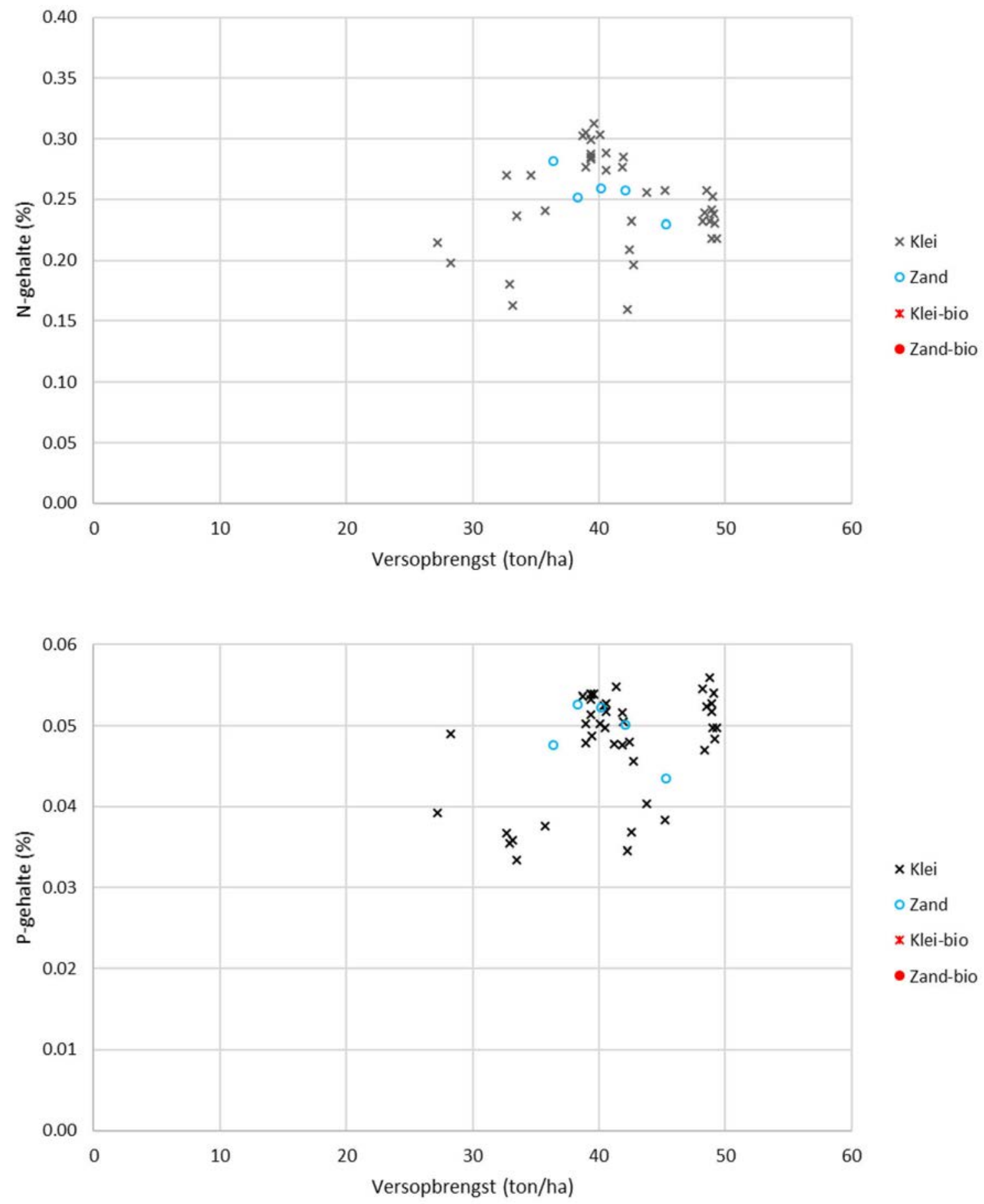


\section{Zetmeelaardappelen}

$\mathrm{N}$-range smal, P-klasse midden
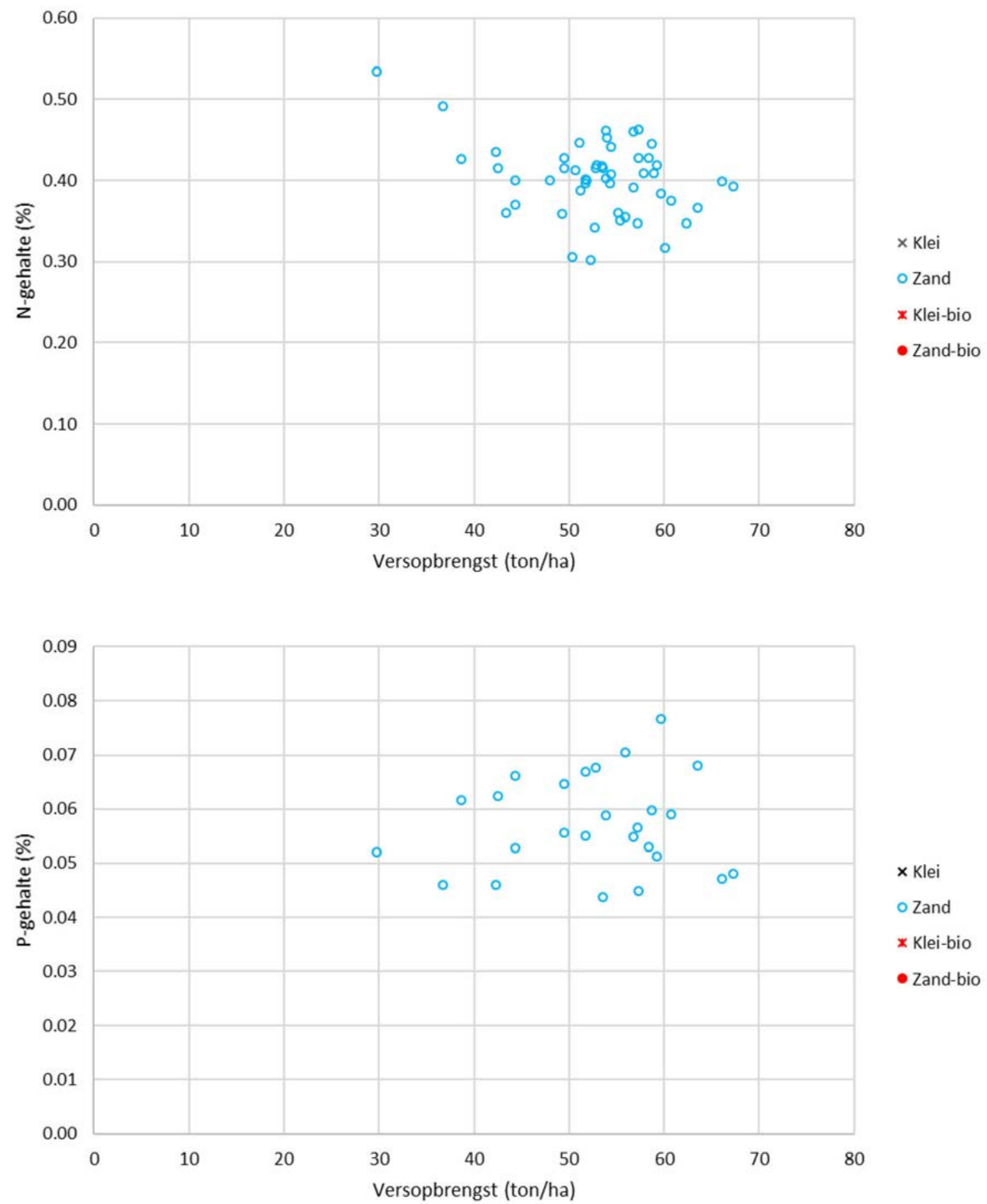


\section{Suikerbieten}

$\mathrm{N}$-range smal, P-klasse midden
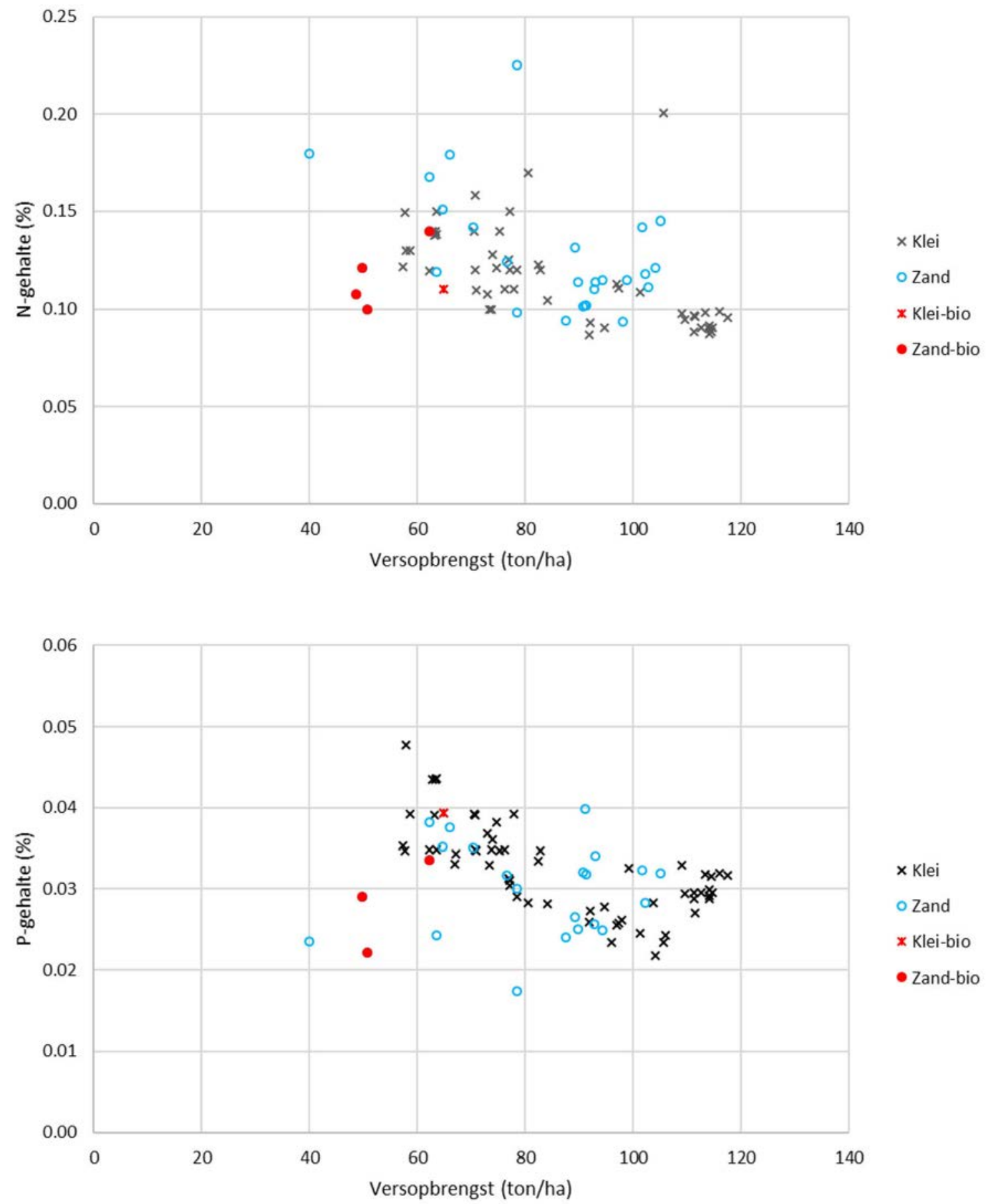


\section{Zaaiuien}

$\mathrm{N}$-range smal, P-klasse midden
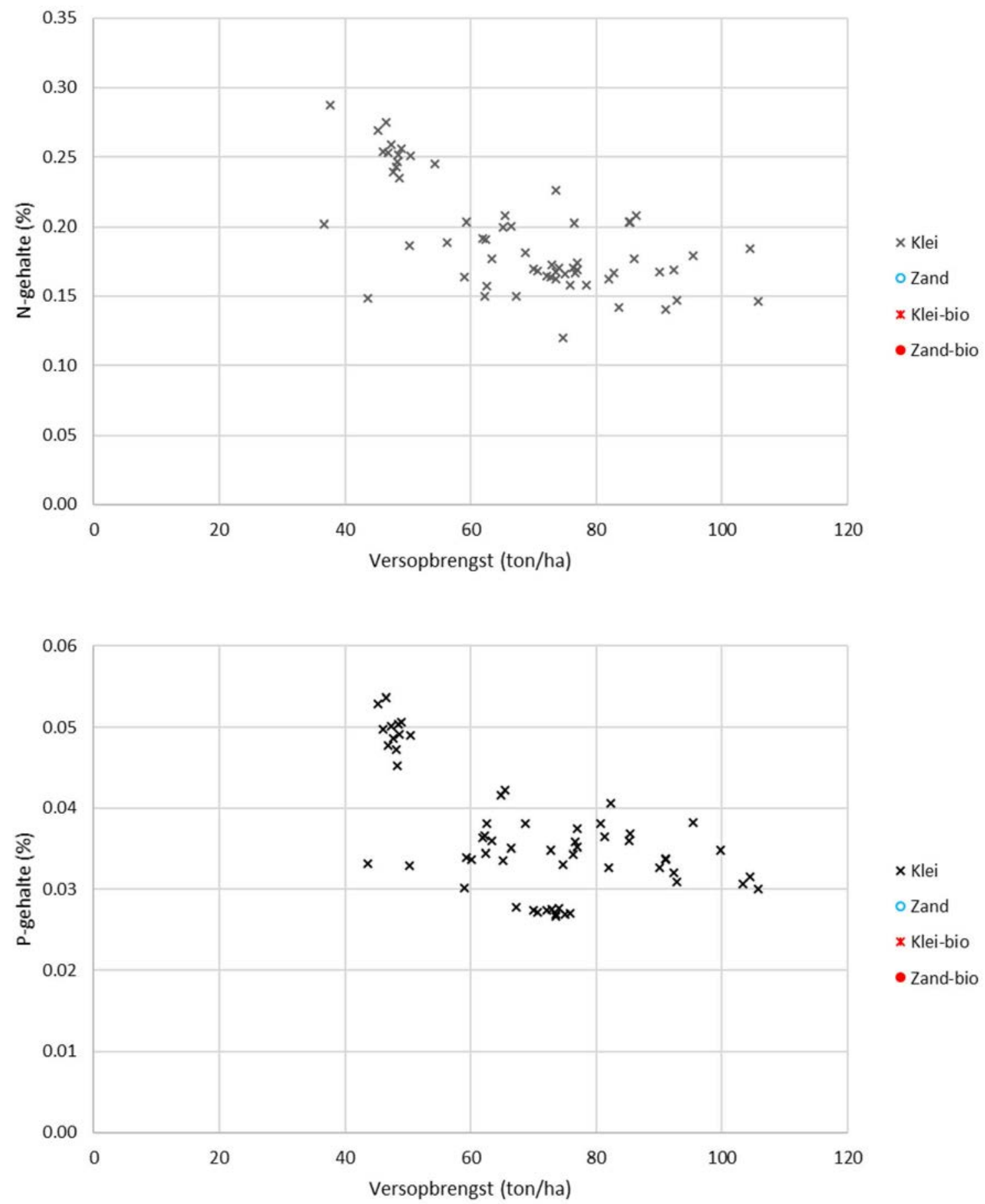


\section{Wintertarwe}

$\mathrm{N}$-range smal, P-klasse alle data
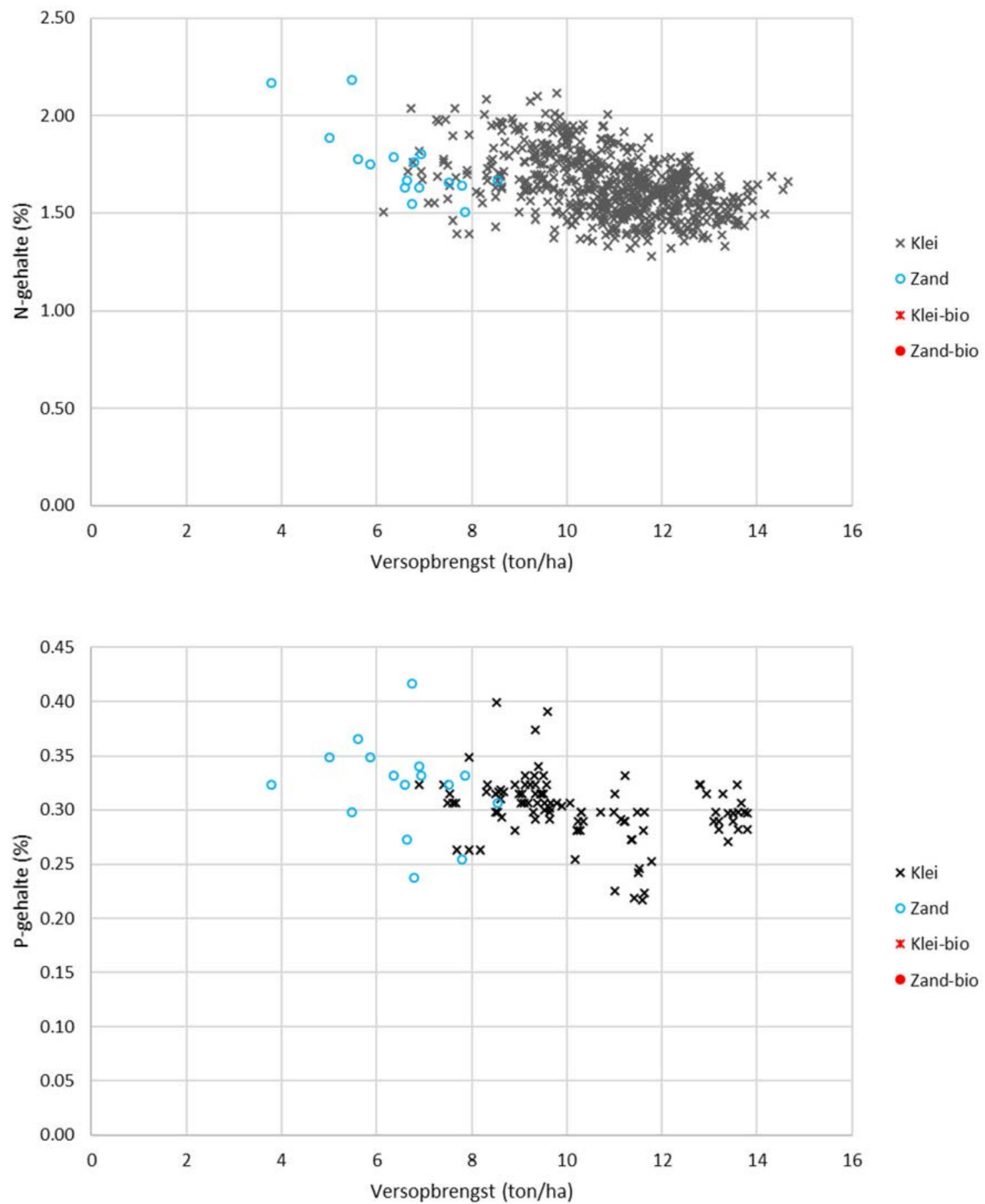


\section{Wintertarwe-stro}

$\mathrm{N}$-range smal, P-klasse verbreed
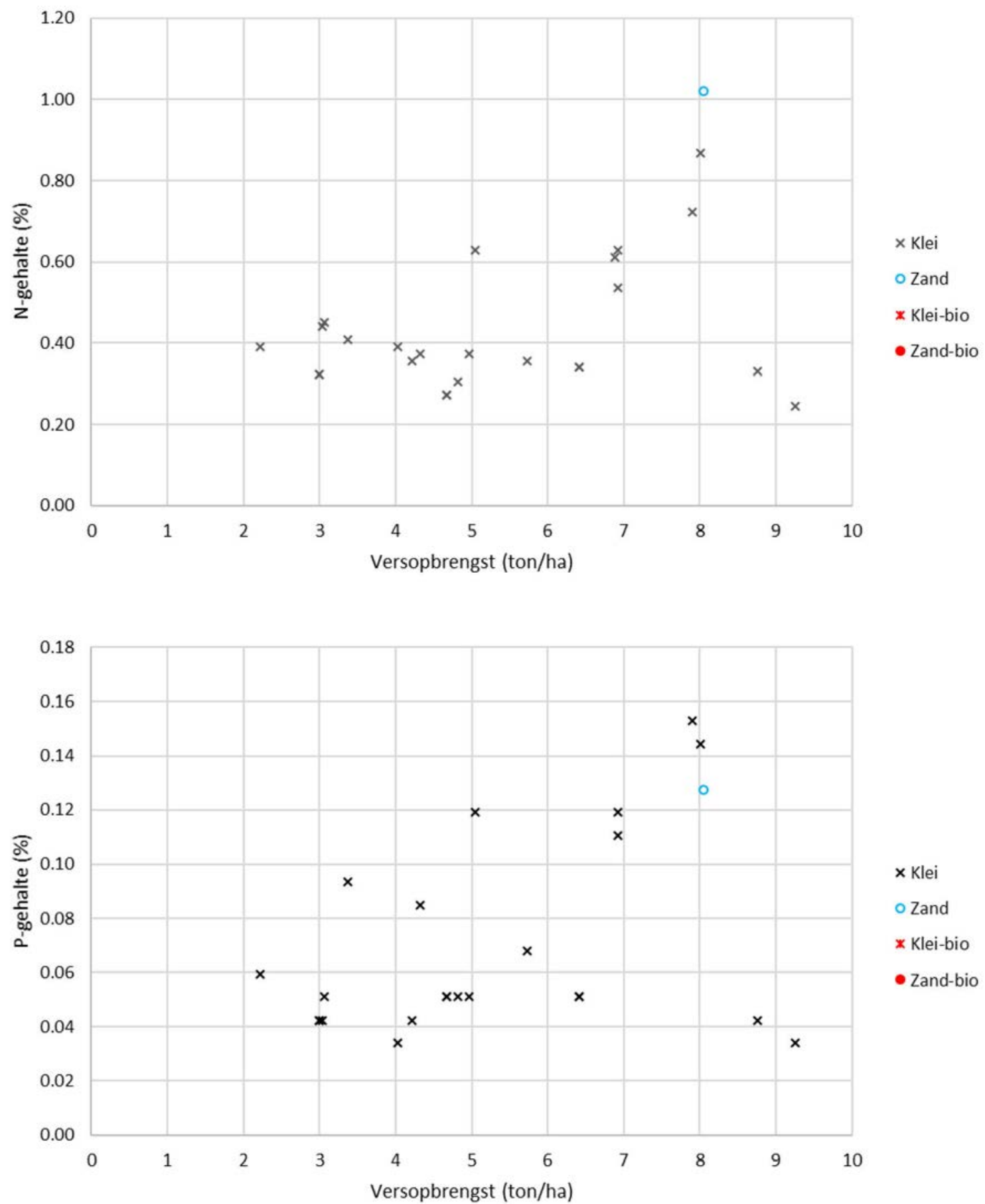


\section{Zomertarwe}

$\mathrm{N}$-range smal, P-klasse verbreed
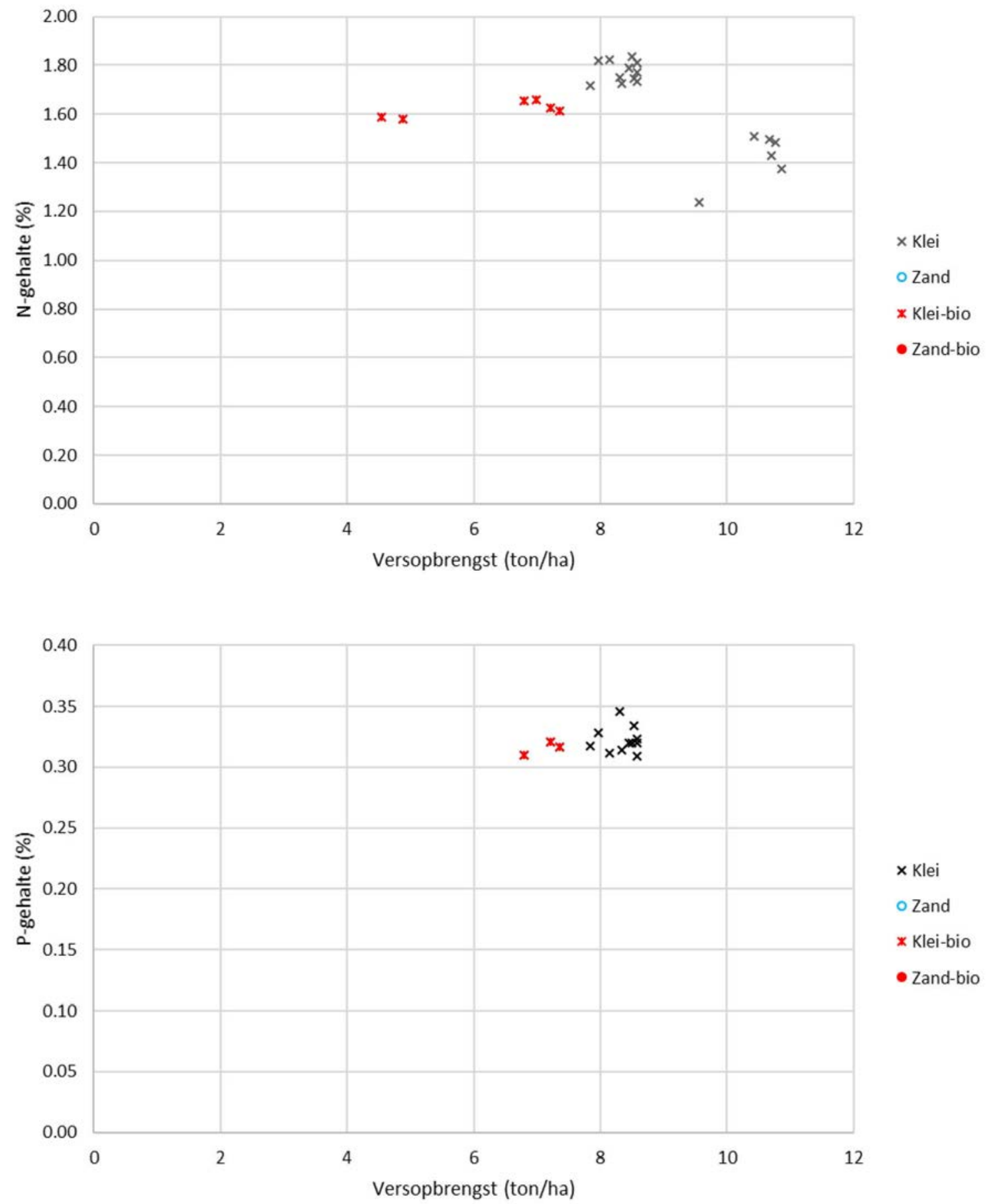


\section{Zomertarwe-stro}

$\mathrm{N}$-range breed, P-klasse alle data

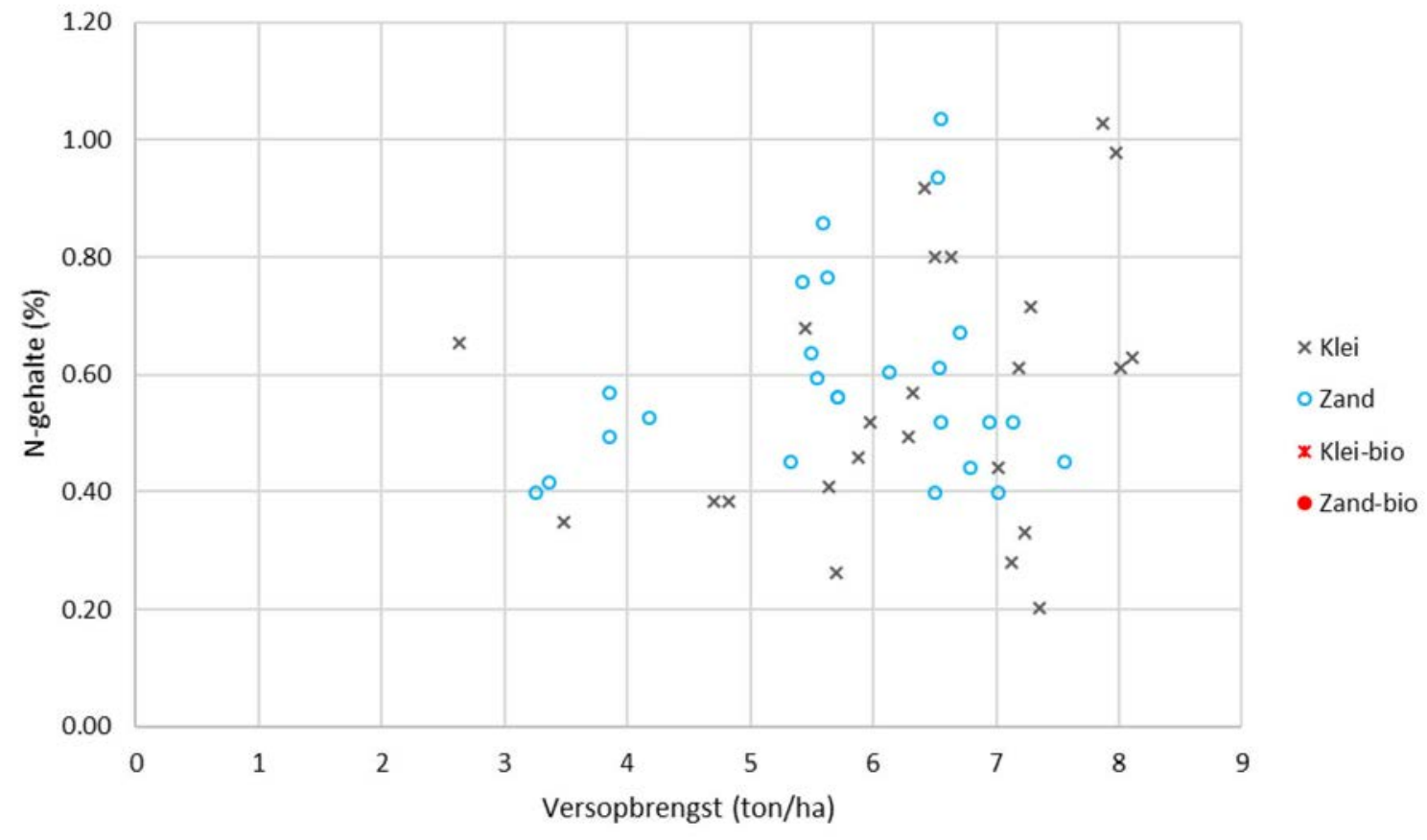

Geen P-gehalten gemeten 


\section{Wintergerst}

$\mathrm{N}$-range smal, P-klasse alle data

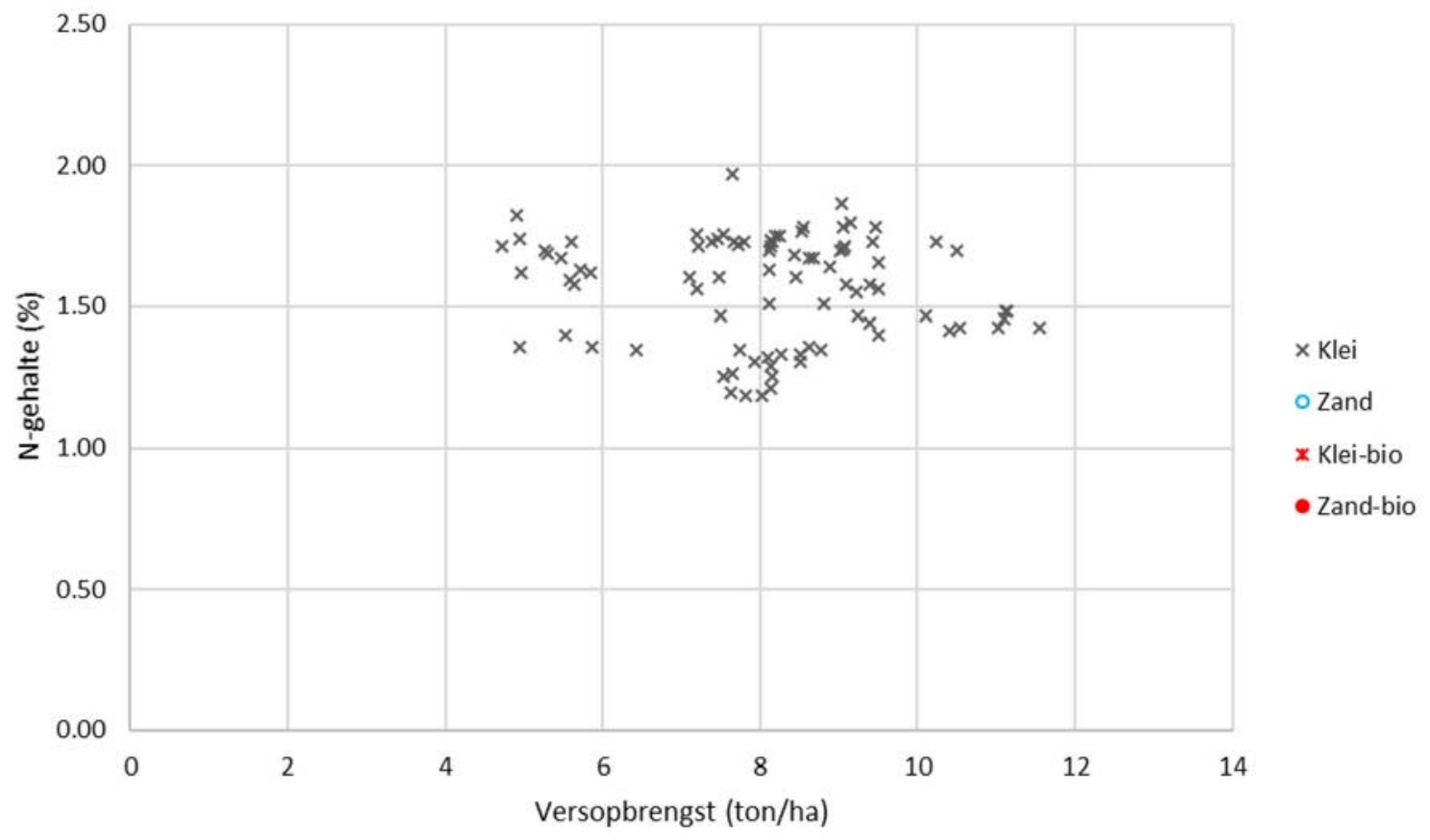

Geen P-gehalten gemeten 


\section{Zomergerst}

$\mathrm{N}$-range smal, P-klasse verbreed
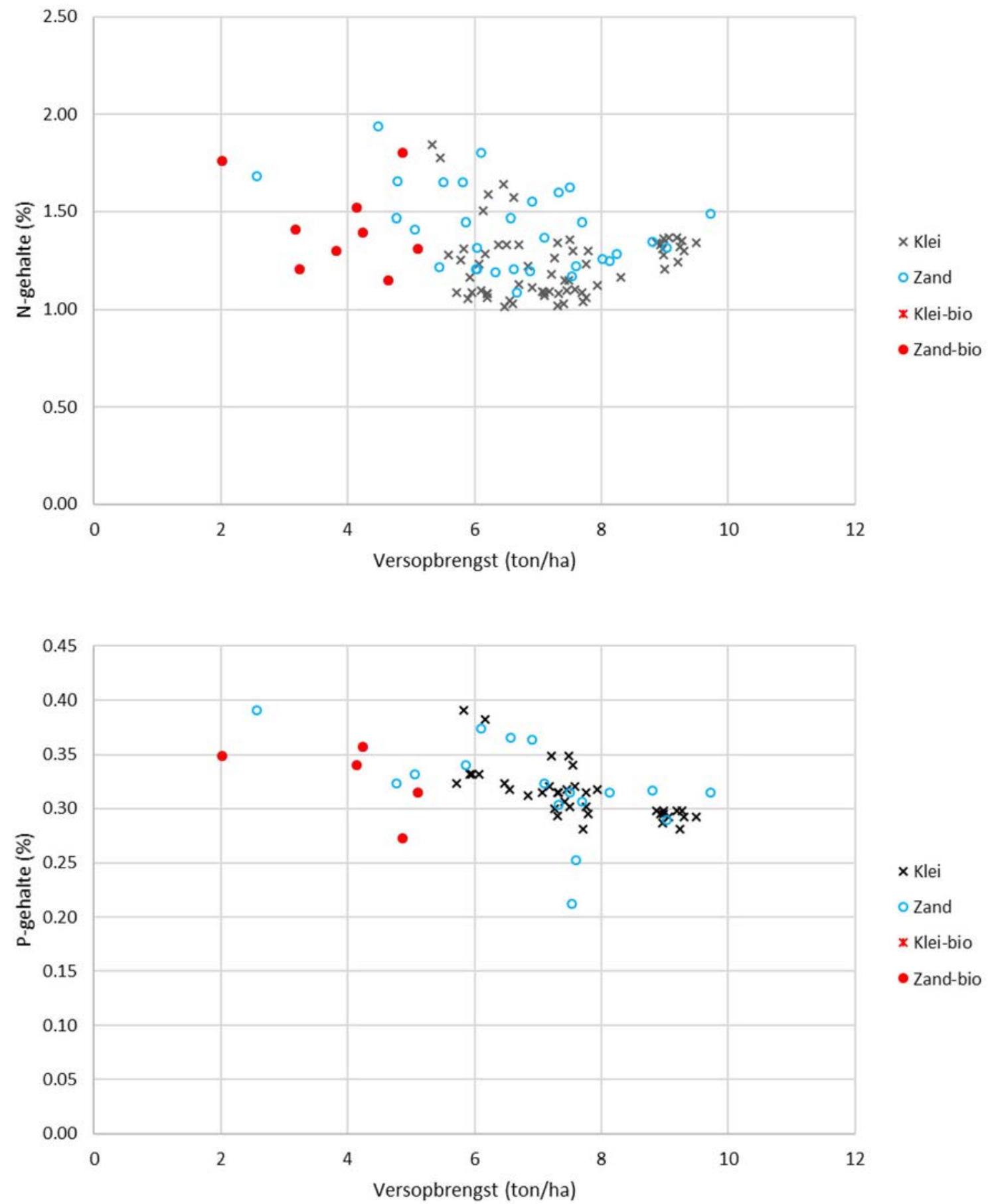


\section{Zomergerst-stro}

$\mathrm{N}$-range breed, P-klasse alle data $(\mathrm{N})$

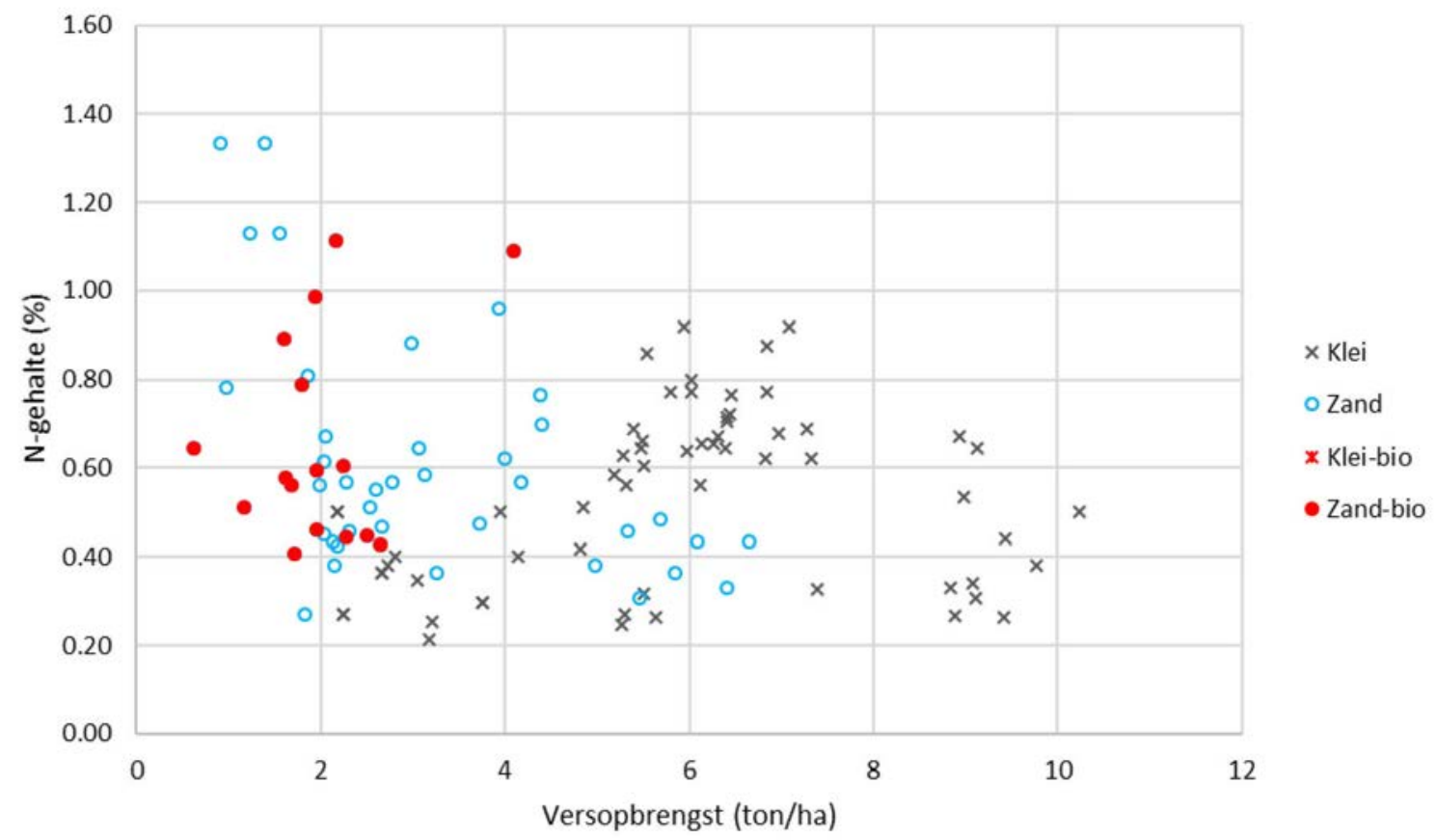

$\mathrm{N}$-range breed, P-klasse verbreed $(\mathrm{P})$

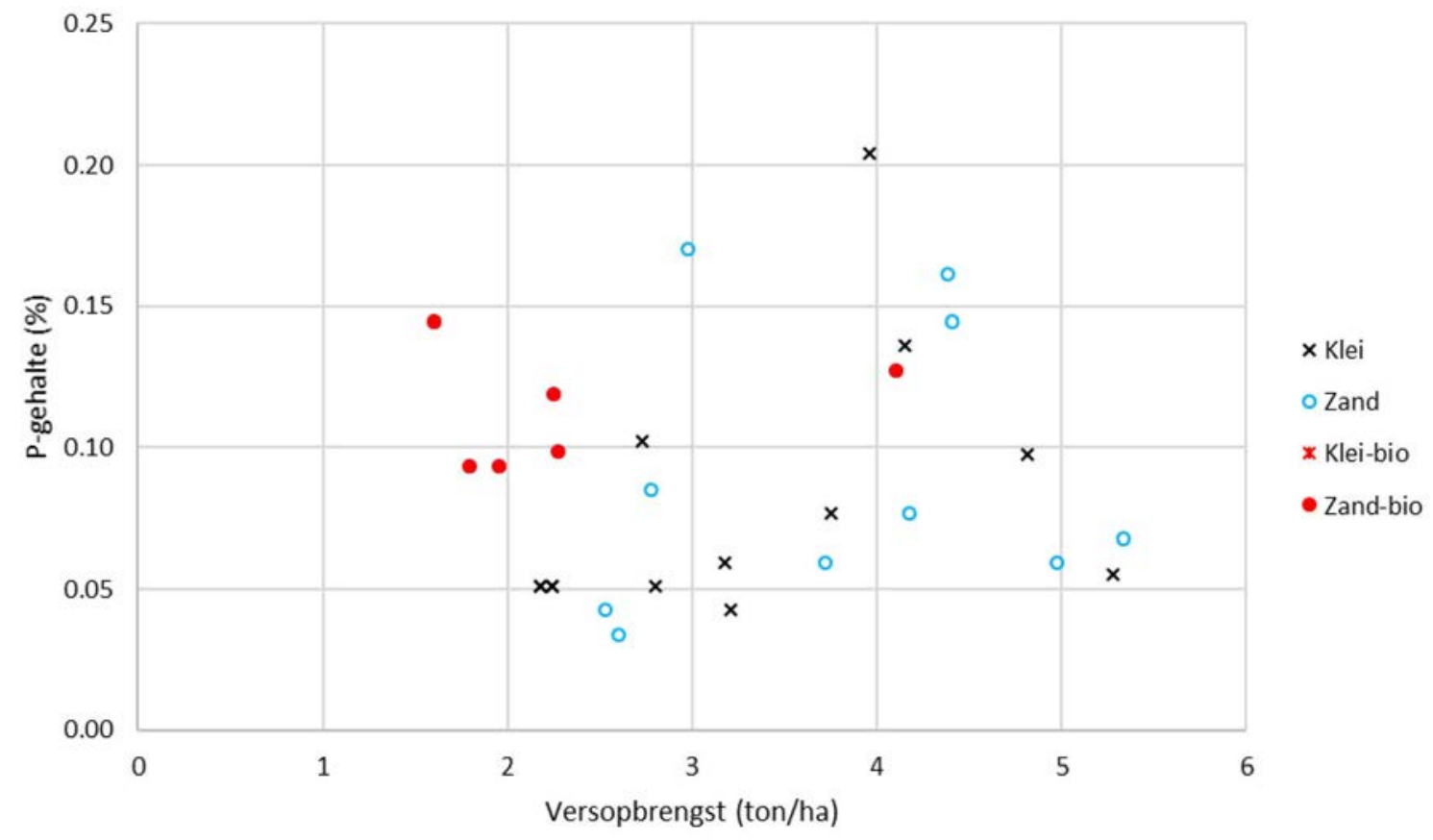




\section{Was- en winterpeen}

$\mathrm{N}$-range breed, P-klasse alle data
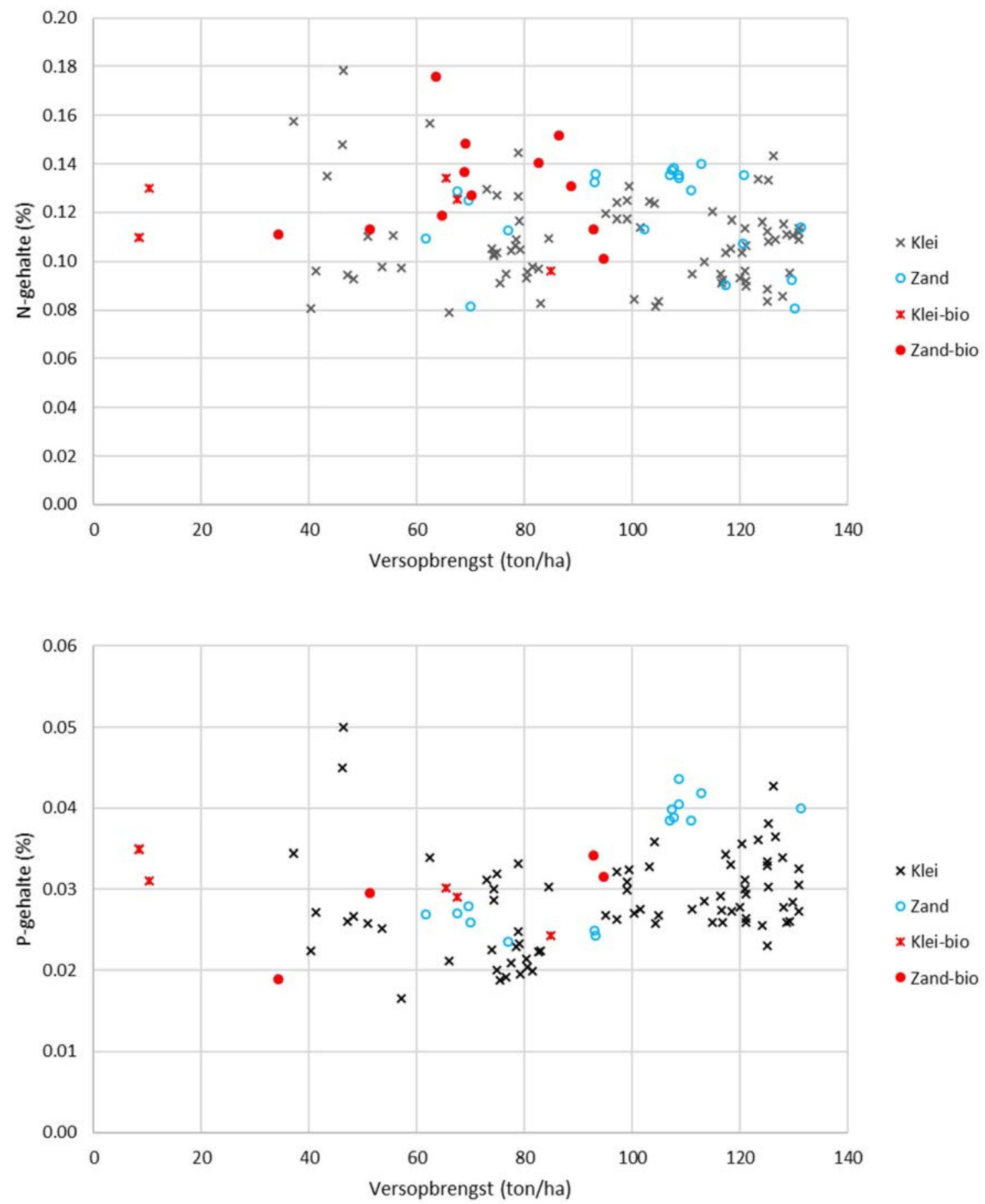


\section{Snijmais}

$\mathrm{N}$-range smal, P-klasse midden
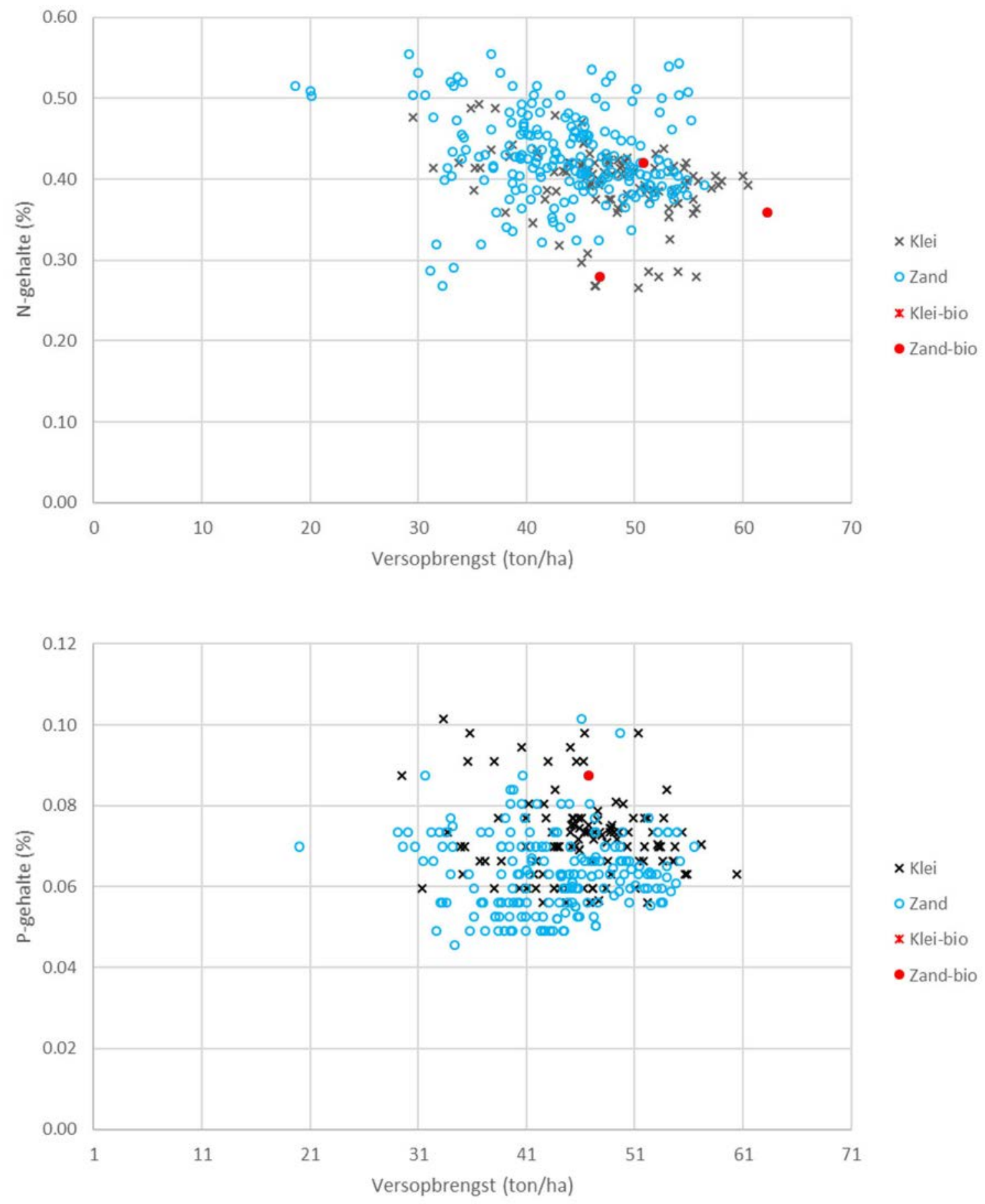


\section{Korrelmais}

$\mathrm{N}$-range breed, $\mathrm{P}$-klasse alle data
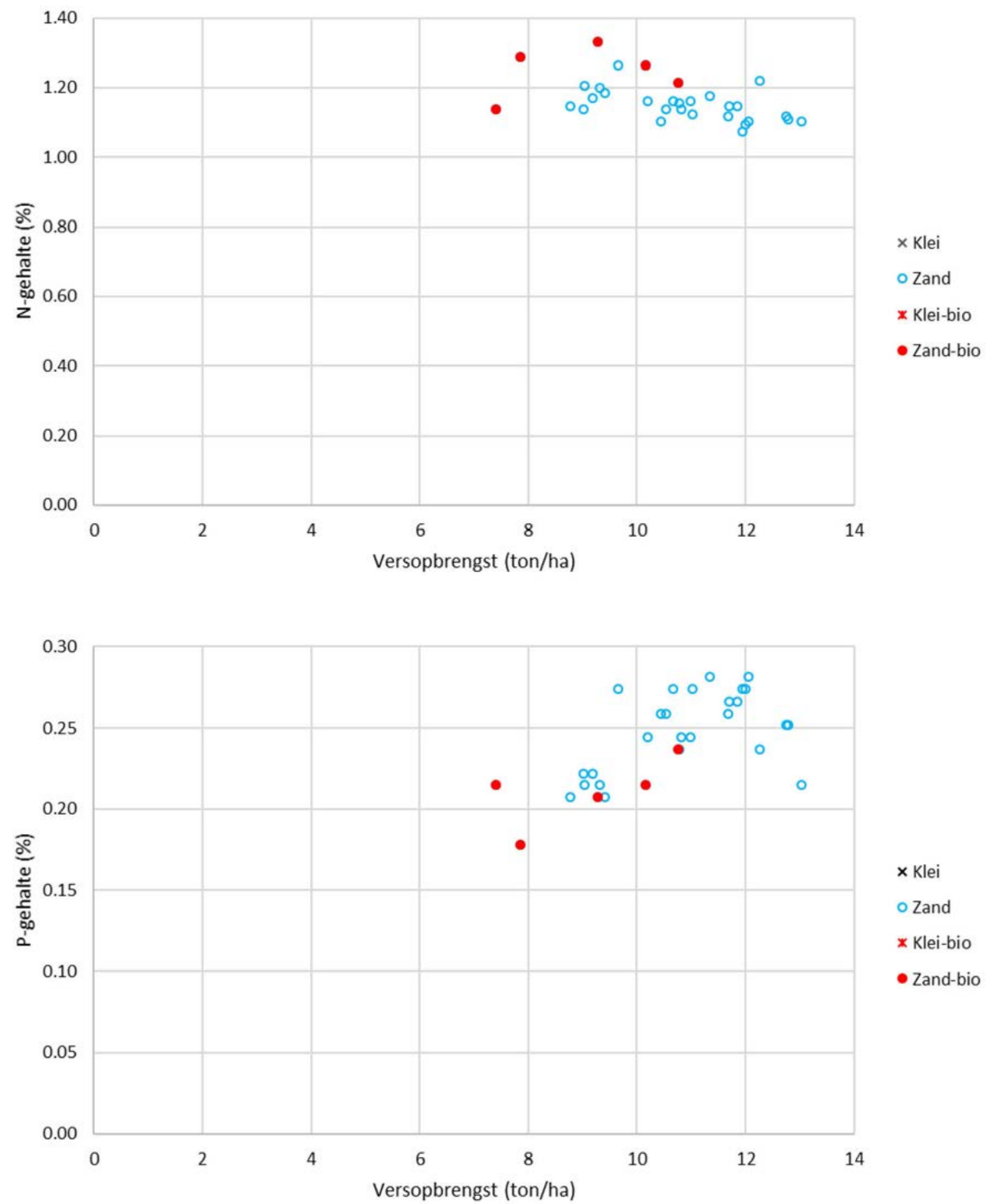


\section{Korrelmais-stro}

$\mathrm{N}$-range breed, $\mathrm{P}$-klasse alle data
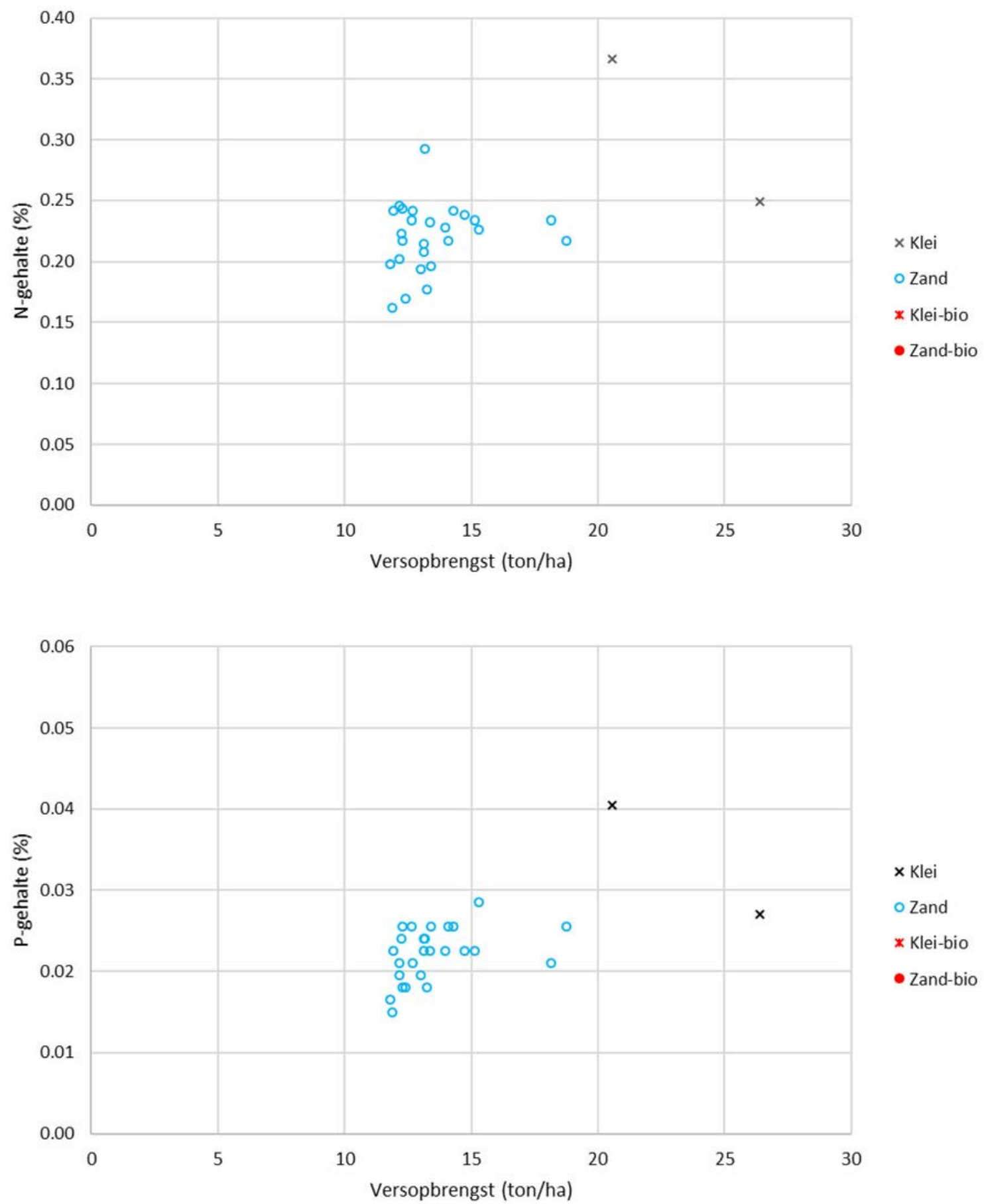


\section{Bijlage 9 Fabrieksbalans fosfaat suikerbieten}

Memo Fosfaatafvoer suikerbieten 2014-2017, Suikerunie

Arjen Buijze, 26 september 2018

De hoeveelheid afvoer van $\mathrm{P}_{2} \mathrm{O}_{5}$ per ton suikerbieten varieert de laatste vier campagnejaren (2014 tot 2017) van 0,81 tot $0,93 \mathrm{~kg}$ fosfaat per ton suikerbieten. In onderstaande tabellen is de totstandkoming van dit getal uitgewerkt. Vanuit wegingen en fosfaatmonsters van betacal, bietenpulp, melasse, bietenpunten en tarragrond wordt de totale hoeveelheid fosfaat berekend, die gedeeld wordt door de aangeleverde tonnen bieten.

Gemiddeld wordt een $70 \%$ van deze totale fosfaathoeveelheid afgevoerd via betacal, $17 \%$ via bietenpulp, $0 \%$ via melasse (daarom is melasse vanaf 2015 buiten beschouwing gelaten), $2 \%$ via bietenpunten en $12 \%$ via tarragrond.

De totale afvoer via tarragrond varieert uiteraard met het tarrapercentage. Voor het berekenen van de totale aangevoerde hoeveelheid fosfaat vanuit tarragrond is uitgegaan van een gelijke verdeling van grondsoorten (zand, klei, löss) met een gemiddeld fosfaatgehalte van $0,12 \%$

\begin{tabular}{|c|c|c|}
\hline $\begin{array}{l}\mathbf{2 0 1 4} \text { Suiker Unie totaal } \\
\text { productie bieten: } 6.587 .856 \text { ton }\end{array}$ & $\begin{array}{r}\mathrm{P}_{2} \mathrm{O}_{5} \\
\text { (ton) }\end{array}$ & $\begin{array}{r}\text { aandeel } \\
(\%)\end{array}$ \\
\hline Betacal & 4,378 & $71 \%$ \\
\hline perspulp & 1,164 & $19 \%$ \\
\hline bietenpunten & 49 & $1 \%$ \\
\hline totaal bruto & 5,591 & \\
\hline tarragrond & 535 & $9 \%$ \\
\hline totaal netto & 6,128 & $100 \%$ \\
\hline 2015 Suiker Unie totaal & $\mathrm{P}_{2} \mathrm{O}_{5}$ & aandeel \\
\hline productie bieten: 4.595 .899 ton & (ton) & $(\%)$ \\
\hline Betacal & 2,619 & $65 \%$ \\
\hline perspulp & 778 & $19 \%$ \\
\hline bietenpunten & 89 & $2 \%$ \\
\hline totaal bruto & 3,486 & \\
\hline tarragrond & 559 & $14 \%$ \\
\hline totaal netto & 4,046 & $100 \%$ \\
\hline $\begin{array}{l}\mathbf{2 0 1 6} \text { Suiker Unie totaal } \\
\text { productie bieten: } 5.584 .130 \text { ton }\end{array}$ & $\begin{array}{l}\mathrm{P}_{2} \mathrm{O}_{5} \\
\text { (ton) }\end{array}$ & $\begin{array}{r}\text { aandeel } \\
(\%)\end{array}$ \\
\hline Betacal & 3,475 & $71 \%$ \\
\hline perspulp & 891 & $18 \%$ \\
\hline bietenpunten & 96 & $2 \%$ \\
\hline totaal bruto & 4,462 & \\
\hline tarragrond & 455 & $9 \%$ \\
\hline totaal netto & 4,916 & $100 \%$ \\
\hline $\begin{array}{l}\mathbf{2 0 1 7} \text { Suiker Unie totaal } \\
\text { productie bieten: } 7.739 .475 \text { ton }\end{array}$ & $\begin{array}{r}\mathrm{P}_{2} \mathrm{O}_{5} \\
\text { (ton) }\end{array}$ & $\begin{array}{r}\text { aandeel } \\
(\%)\end{array}$ \\
\hline Betacal & 4,378 & $70 \%$ \\
\hline perspulp & 745 & $12 \%$ \\
\hline bietenpunten & 192 & $3 \%$ \\
\hline totaal bruto & 5,315 & \\
\hline tarragrond & 979 & $16 \%$ \\
\hline totaal netto & 6,295 & $100 \%$ \\
\hline
\end{tabular}

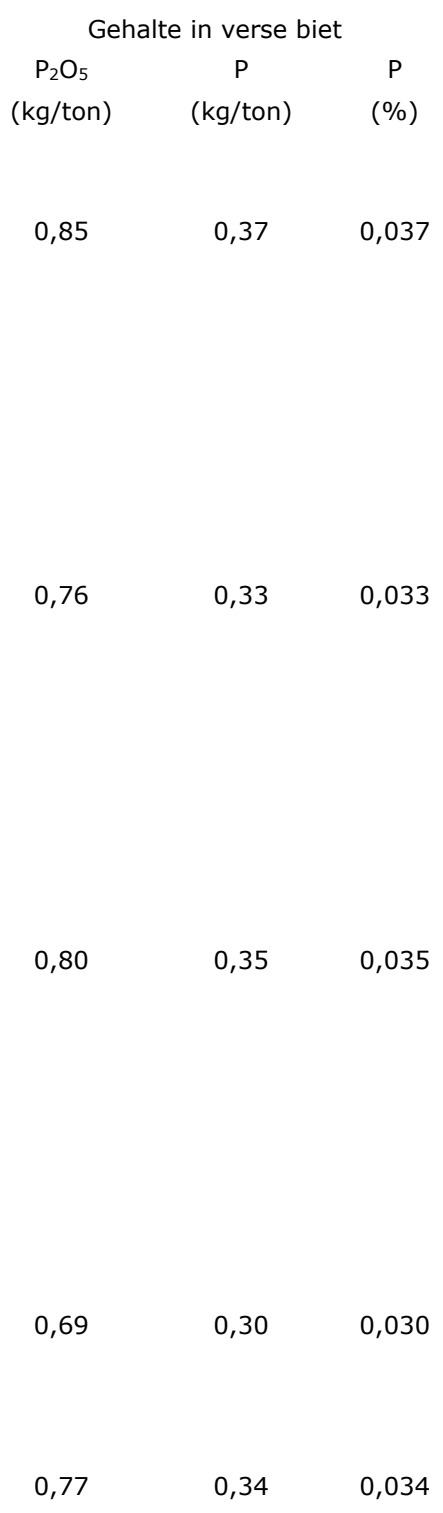


Correspondentie adres voor dit rapport: Postbus 16

6700 AA Wageningen

T 0317480700

www.wur.nl/plant-research

Rapport WPR-957
De missie van Wageningen University \& Research is 'To explore the potential of nature to improve the quality of life'. Binnen Wageningen University \& Research bundelen Wageningen University en gespecialiseerde onderzoeksinstituten van Stichting Wageningen Research hun krachten om bij te dragen aan de oplossing van belangrijke vragen in het domein van gezonde voeding en leefomgeving. Met ongeveer 30 vestigingen, 5.000 medewerkers en 12.000 studenten behoort Wageningen University \& Research wereldwijd tot de aansprekende kennisinstellingen binnen haar domein. De integrale benadering van de vraagstukken en de samenwerking tussen verschillende disciplines vormen het hart van de unieke Wageningen aanpak. 



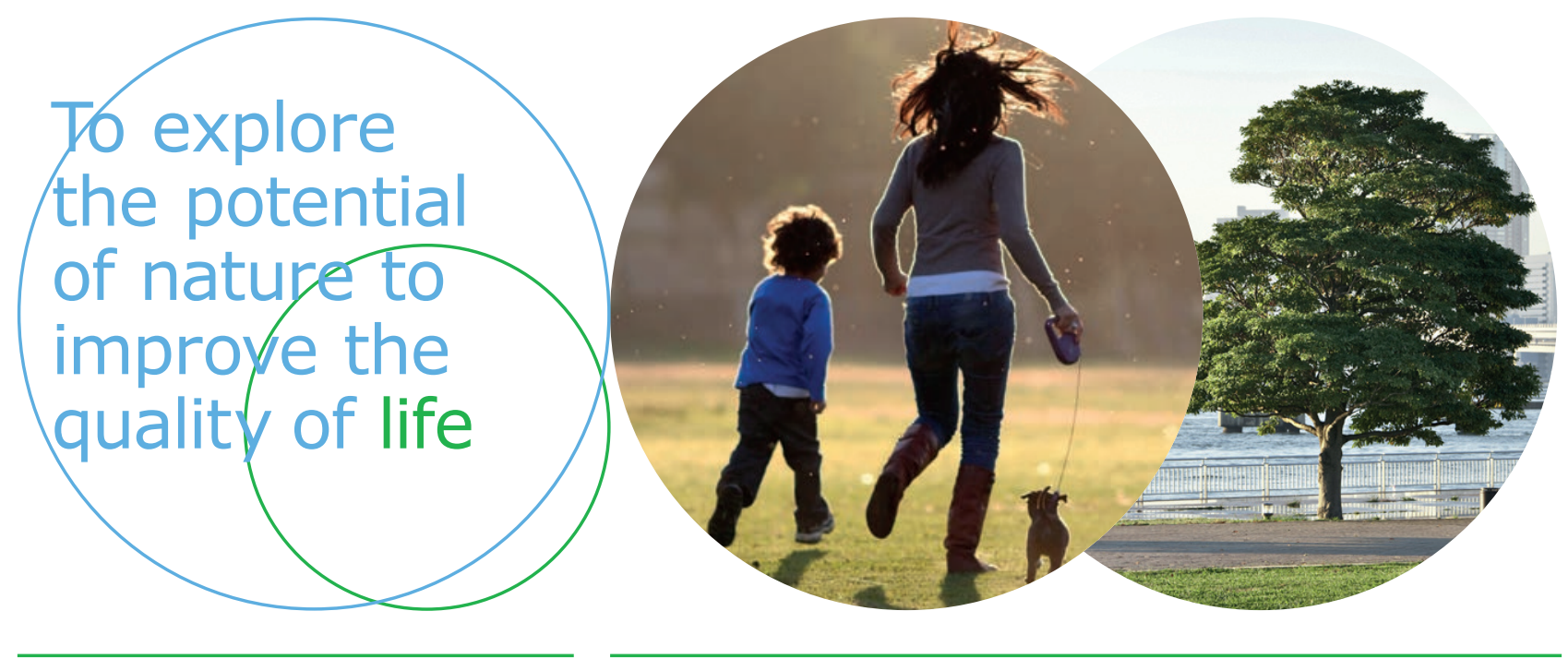

Corresponding address for this report: Postbus 16

6700 AA Wageningen

T 0317480700

www.wur.nl/plant-research

Rapport WPR-957
De missie van Wageningen University \& Research is 'To explore the potential of nature to improve the quality of life'. Binnen Wageningen University \& Research bundelen Wageningen University en gespecialiseerde onderzoeksinstituten van Stichting Wageningen Research hun krachten om bij te dragen aan de oplossing van belangrijke vragen in het domein van gezonde voeding en leefomgeving. Met ongeveer 30 vestigingen, 5.000 medewerkers en 12.000 studenten behoort Wageningen University \& Research wereldwijd tot de aansprekende kennisinstellingen binnen haar domein. De integrale benadering van de vraagstukken en de samenwerking tussen verschillende disciplines vormen het hart van de unieke Wageningen aanpak. 